\title{
37. EARLY CRETACEOUS AND TITHONIAN MAGNETOSTRATIGRAPHY OF THE GALICIA MARGIN (OCEAN DRILLING PROGRAM LEG 103) ${ }^{1}$
}

\author{
James G. Ogg, Department of Earth and Atmospheric Science, Purdue University, West Lafayette, Indiana
}

\begin{abstract}
Lower Cretaceous and Tithonian sediments were sampled for magnetostratigraphy at six holes (Holes 638B, 638C, $639 \mathrm{~A}, 639 \mathrm{D}, 640 \mathrm{~A}$, and $641 \mathrm{C}$ ). Magnetic polarity chrons were assigned to polarity zones using biostratigraphic constraints.

In Holes 638B and 638C, polarity Chrons M3 and perhaps M1 are present in the upper part, M4 and M5 are apparently absent, M6 through M9 are poorly represented, M10 and M10N are apparently absent, and M11 and M12 are tentatively assigned to the lower part. Strata in Holes 638B and 638C dip toward the south.

In Hole 639A, polarity Chron M13 is well documented and M12A may be present. In Hole 639D, polarity Chrons M19 through M21 may be present, but the data is poor. Hole 640A had inadequate recovery to identify polarity chrons.

In Hole $641 \mathrm{C}$, polarity Chron M0 is well documented and occurs significantly above the nannofossil marker of the Barremian/Aptian boundary; comparison to Italian magnetostratigraphy implies that this nannofossil datum is timetransgressive.
\end{abstract}

\section{INTRODUCTION}

Leg 103 of the Ocean Drilling Program (ODP) was primarily devoted to drilling the Mesozoic sediments of the seaward edge of the Galicia margin, northwest of the Iberian Peninsula (Fig. 1). Multiple-hole Sites 638,639 , and $641\left(42.1^{\circ} \mathrm{N}, 12.2^{\circ} \mathrm{W}\right.$ average coordinates) yielded a composite stratigraphy of the Upper Jurassic through Cretaceous sediments. Hole $640 \mathrm{~A}\left(42.0^{\circ} \mathrm{N}\right.$, $12.5^{\circ} \mathrm{W}$ ) recovered a second section of upper Lower Cretaceous sediments. The Upper Jurassic sediments are shallow-water carbonates capped by a thick dolomite. The overlying Lower Cretaceous sediments consist primarily of pelagic carbonates with abundant turbidite beds.

The objectives of this paleomagnetic project were to obtain magnetostratigraphic correlations to the Lower Cretaceous sediments previously recovered in the western Central Atlantic and to improve the calibration of the magnetic polarity chrons to biostratigraphic zones of the Early Cretaceous, especially for polarity Chron M0.

Additional paleomagnetic studies were made of the peridotite basement drilled at Site 637 and of the unconsolidated Neogene carbonates and brown clays of Late Cretaceous or early Tertiary age recovered at all Leg 103 sites. Results from these studies and preliminary paleomagnetic interpretations for the Mesozoic sediments are given in the appropriate site chapters in the Initial Reports of this volume (Boillot, Winterer, et al., 1987).

The main results of this paleomagnetic study are (1) demonstration that the nannofossil marker commonly used to identify the "Barremian/Aptian boundary" is significantly diachronous with respect to polarity Chron M0; (2) assignment of magnetic polarity chrons and corresponding improved precision on ages of sediments from Holes 638B, 639A, 639D, and 641C; and (3) determination that the orientation of the dipping structures is toward the south with respect to "Early Cretaceous North."

\footnotetext{
${ }^{1}$ Boillot, G., Winterer, E. L., et al., 1988. Proc. ODP, Sci. Results, 103: College Station, TX (Ocean Drilling Program).
}

\section{STATUS OF THE LATE JURASSIC AND EARLY CRETACEOUS MAGNETIC POLARITY TIME SCALE}

\section{M-Sequence Correlations}

The standard scale for the identification and nomenclature of magnetic polarity zones of Oxfordian through Aptian age is the pattern of normal- and reversed-polarity magnetized blocks of oceanic crust used to model the Hawaiian marine magnetic lineations that formed at the ancient spreading center between the Pacific and Farallon plates (summarized by Larson and Hilde, 1975). The numbered magnetic anomalies of this "M-Sequence" provide a system of nomenclature for intervals of time in which "magnetic polarity chrons" are represented by corresponding "polarity zones" of magnetostratigraphy (e.g., notation proposed by Harland et al., 1982, and guidelines of IUGS, 1979). The Msequence pattern has been correlated in large part to the magnetic anomaly pattern left by other spreading centers in the Pacific, Atlantic, and Indian oceans, although some major difficulties remain in correlating the M11 through M4 part (late Valanginian through early Barremian) to the western Atlantic pattern (e.g., Vogt and Einwich, 1979; Schouten and Klitgord, 1977, 1982; Sundvik, 1985; Klitgord and Schouten, 1987). Whether the M-sequence pattern was formed by a constant rate of spreading and without any ridge jumps for the approximately 40 m.y. represented by the Hawaiian lineations remains unknown.

Several studies have correlated parts of the M-sequence to magnetostratigraphy derived from sedimentary sections thereby enabling assignment of biostratigraphic datum horizons to polarity chrons. The biostratigraphic correlations include ammonite, dinoflagellate, nannofossil, calpionellid, and foraminifer datum horizons. There have been several recent reviews and compilations of these biostratigraphic-magnetostratigraphic studies (e.g., Kent and Gradstein, 1985; Lowrie and Ogg, 1986; Ogg and Lowrie, 1986; Ogg, 1987), which are summarized in Figure 2. This figure includes the results from recent investigation of Deep Sea Drilling Project (DSDP) Sites 534 and 603 (Ogg, 1987); nannofossil datum horizons of Italian sections (Bralower, 1984, 1986; Channell et al., 1987), and early Valanginian calpio- 
A

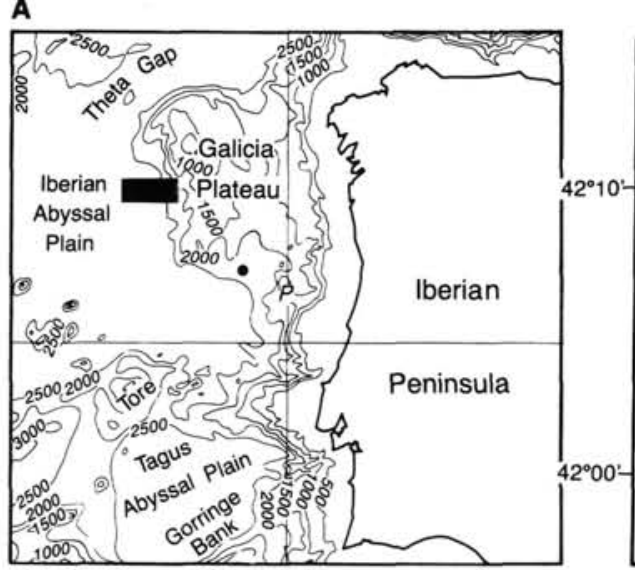

B

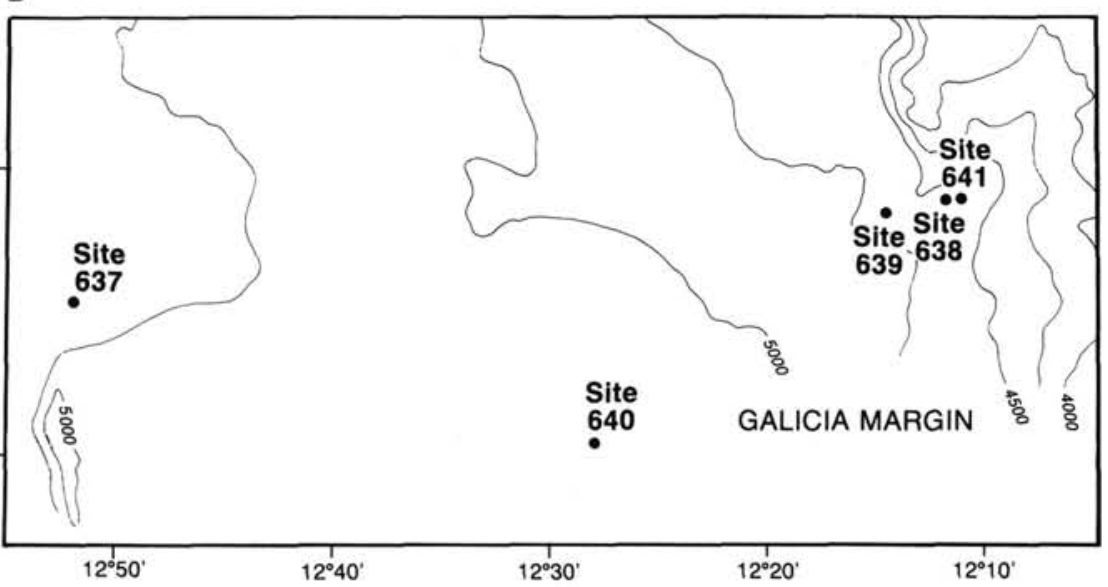

Figure 1. A. Generalized bathymetry of the Galicia margin. B. ODP Leg 103 drill sites on the Galicia margin. Map location outlined in Figure 1A.

nellids in Italian sections (Grandesso and Channell, 1986; Channell and Grandesso, 1987).

\section{Reliability of Biostratigraphic Datum Horizons and Polarity Chron Correlations}

Some of the biostratigraphic datum horizons shown in Figure 2 , especially some nannofossil datum levels, differ in their correlation to the magnetic polarity chron assignments among sections. Part of this variability may represent errors in assigning polarity chrons to magnetic polarity zones of the magnetostratigraphy; however, apparent time-transgressive behavior of the datum levels is also present.

Assignment of polarity chrons to polarity zones is difficult for Hauterivian-lower Barremian sediments because the M-sequence from M10 through M4 lacks a distinctive "fingerprint," and instead, the pattern consists of repeating intervals of similar length. Published correlations of biostratigraphy to polarity chrons may have incorporated misinterpretations of the magnetostratigraphy, as was observed for some Tithonian/Berriasian studies (reviewed by Ogg and Lowrie, 1986).

Bralower (1987) observed apparent diachroneity of nannofossil datum horizons in Italian sections and concluded that the main factor in these apparent time-transgressions was either differential preservation or discontinuous sedimentation. Another factor is the low probability of finding rare or fragile species near the beginning or end of their ranges. However, some of this diachroneity is a real phenomenon due to paleoecological and paleogeographic variability in the range of occurrence of species. Such diachroneity, as documented by a reversal in the sequence of Early Cretaceous nannofossil datum levels, is present within the Atlantic-Tethys region (Ogg, this study and 1987) and between the Pacific and Atlantic-Tethys basins (Bralower, 1987). Also, some key species (e.g., Lithraphidites bollii) seem to have only regional occurrences (see discussions in Applegate and Bergen, this volume). Therefore, these sources of variability in the correlation of biostratigraphic datum levels to polarity chrons imply that (1) one must be careful in assigning polarity chrons to the polarity zones in a magnetostratigraphic section if the main criteria are the paleontological "constraints" and (2) the exact correlation of polarity chrons to standard geological stages (e.g., the Valanginian/Hauterivian boundary) is not yet fixed.

For these reasons, the magnetic polarity time scale compiled in Figure 2 is the guide for assigning polarity chrons to the polarity zones of the Leg 103 sites but is not a strict control.

\section{STRATIGRAPHIC AND TECTONIC HISTORY}

\section{Tectonic History and Lithostratigraphy}

The structural setting and sedimentation history of the various sites are given in the appropriate site survey and site report chapters (Boillot, Winterer, et al., 1987) and are briefly summarized in the following.

The Galicia margin consists of a series of north-trending, elongate blocks with gentle dips toward the east or southeast. These blocks underwent pulses of tilting during the Early Cretaceous as Newfoundland and Iberia progressively rifted apart. Because of this tilting, most of the Upper Jurassic and Lower Cretaceous sediments display a dip of between $10^{\circ}$ and $15^{\circ}$ in the drill cores. This tilt of the lamination or bedding enabled a calculation of magnetic declination relative to the direction of dip (Fig. 3). This consistent apparent dip aided in deciphering the polarity of samples for magnetostratigraphy (e.g., identification of blocks of opposing declinations) but complicated the calculation of true paleolatitudes because of the need for an accurate structural correction. The structural dip was initially assumed to be eastward, but, as will be demonstrated subsequently, some of the structural dips appear to be southward or even westward.

Prior to the first major stage of rifting in the latest Jurassic or earliest Cretaceous, a shallow-water-shelf environment is indicated by gray to tan, bioclastic-pellet-oncolite limestones of Tithonian age (Hole 639D), which are overlain by massive dolomite. The pelagic sediment directly above the drowned platform is a thin interval of lower Valanginian marl (Hole 639A). Thick wedges of terrigenous turbidites interbedded with laminated or bioturbated clayey limestones partially filled the active fault basins during the Valanginian (Holes 638B and 638C). The bulk of the recovered Hauterivian sediment is a pelagic limestone that has been distorted by slumping (Holes 638B and 640A). Deposition of upper Barremian through Aptian gray marl with some interbedded turbidites (Hole 641C) completes the Early Cretaceous sedimentation during and immediately after rifting.

The Upper Cretaceous through lower Tertiary sediments are predominantly a sequence of greenish gray to brown claystone; these are overlain by upper Miocene to Pleistocene calcareous ooze. Only a few paleomagnetic samples of these sediments were analyzed; the results are given in the appropriate site chapters (Boillot, Winterer, et al., 1987).

Most of the Lower Cretaceous pelagic carbonates are comparable to the cyclic laminated-bioturbated carbonates typical 


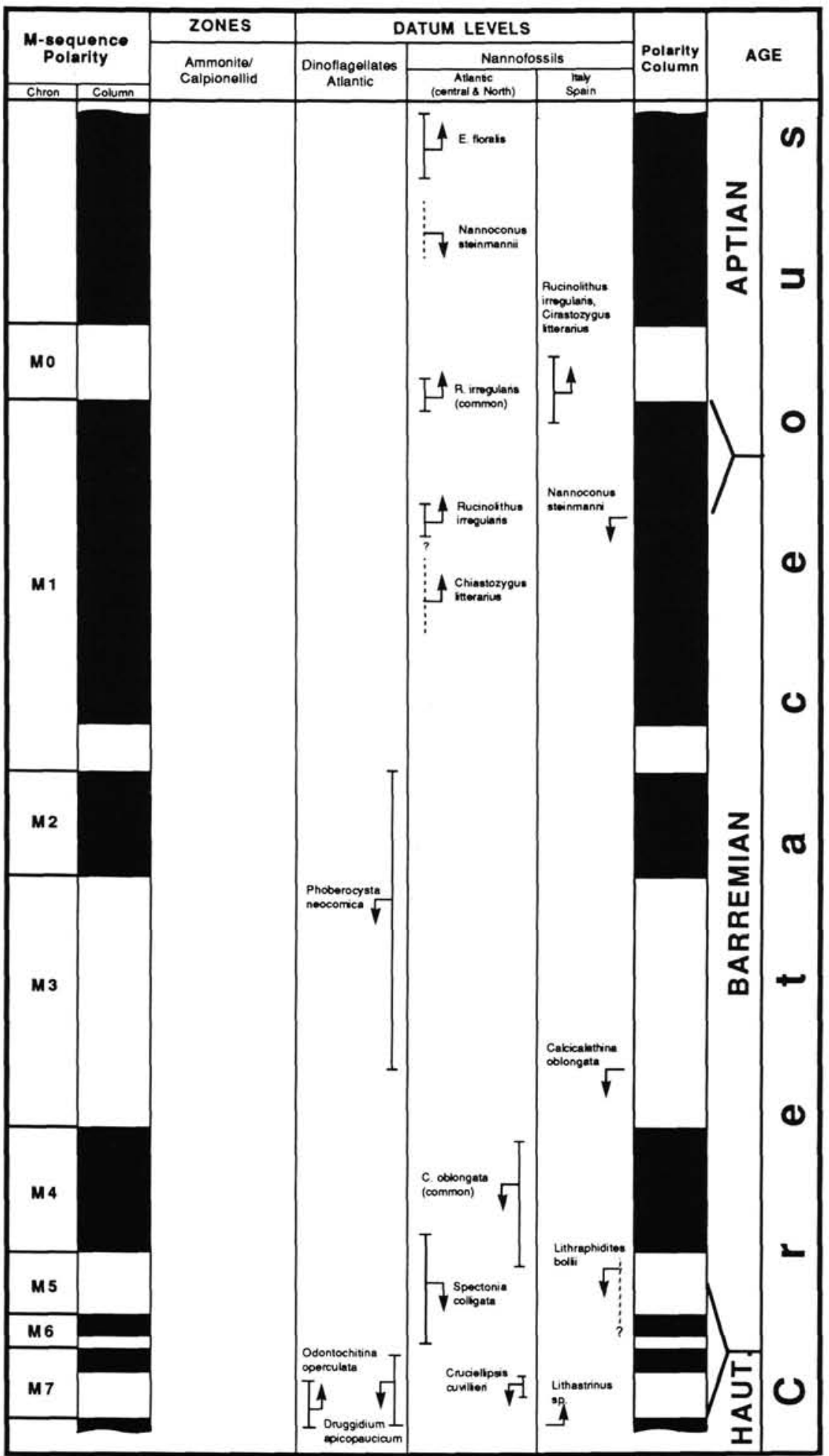

Figure 2. Magnetic polarity time scale for the Early Cretaceous and Late Jurassic. In the magnetic polarity column, black is normal polarity. Polarity chron nomenclature from Harland et al. (1982). Magnetic polarity chrons have been correlated to ammonite zones (from Spain and France), to calpionellid zones and datum levels (from Spain, Italy, France, Hungary and the Central and North Atlantic), to nannofossil datum levels (from Spain, Italy, and the Central and North Atlantic), and to dinoflagellate datum levels (from the Central and North Atlantic). The observed variation of zonal boundaries and of first- and last-appearance datums of taxa with respect to magnetic polarity chrons is indicated. Sources of data and incorporated review articles include Bralower (1986, and in press), Channell and Grandesso (1987), Channell et al. (1987), Galbrun (1984, 1985), Habib and Drugg (1983, 1987), Lowrie and Channell (1984), Marton (1986), Ogg (1981, 1983, 1987, and this study), Ogg and Lowrie (1986), Ogg et al. (1984), and Ogg et al. (1988). This set of studies does not represent all the Late Jurassic and Early Cretaceous magnetostratigraphic work. From Ogg and Steiner (in press). 


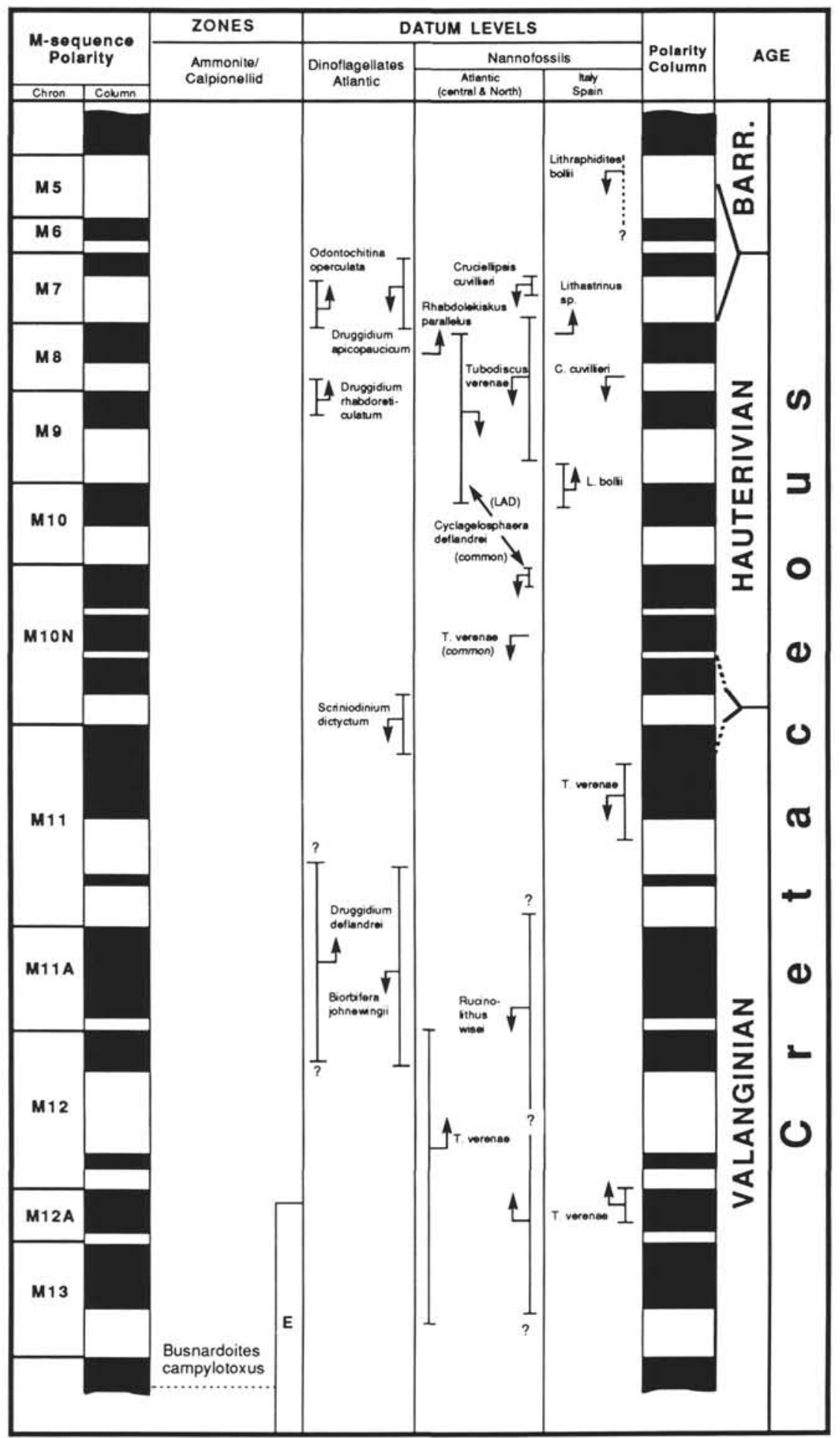

Figure 2 (continued).

of the Blake-Bahama Formation of the western Central Atlantic (Lancelot et al., 1972; Jansa et al., 1979). However, the pelagic sedimentation is represented only by thin intervals between turbidite beds throughout the upper Valanginian and has been disrupted by slumping in the Hauterivian; these distortions preclude application of the pelagic subfacies framework of Ogg et al. (1987) or the cycle stratigraphy of Cotillon and Rio (1984) for the western Central Atlantic.

\section{Biostratigraphy}

Age control in the Lower Cretaceous sediments is primarily from nannofossil, dinoflagellate, and microfossil (foraminifer and calpionellid) biostratigraphy.

The biostratigraphy of Early Cretaceous nannofossils used on Leg 103 (Applegate and Bergen, this volume) is based on seven first- and last-appearance datum horizons and the zonal 


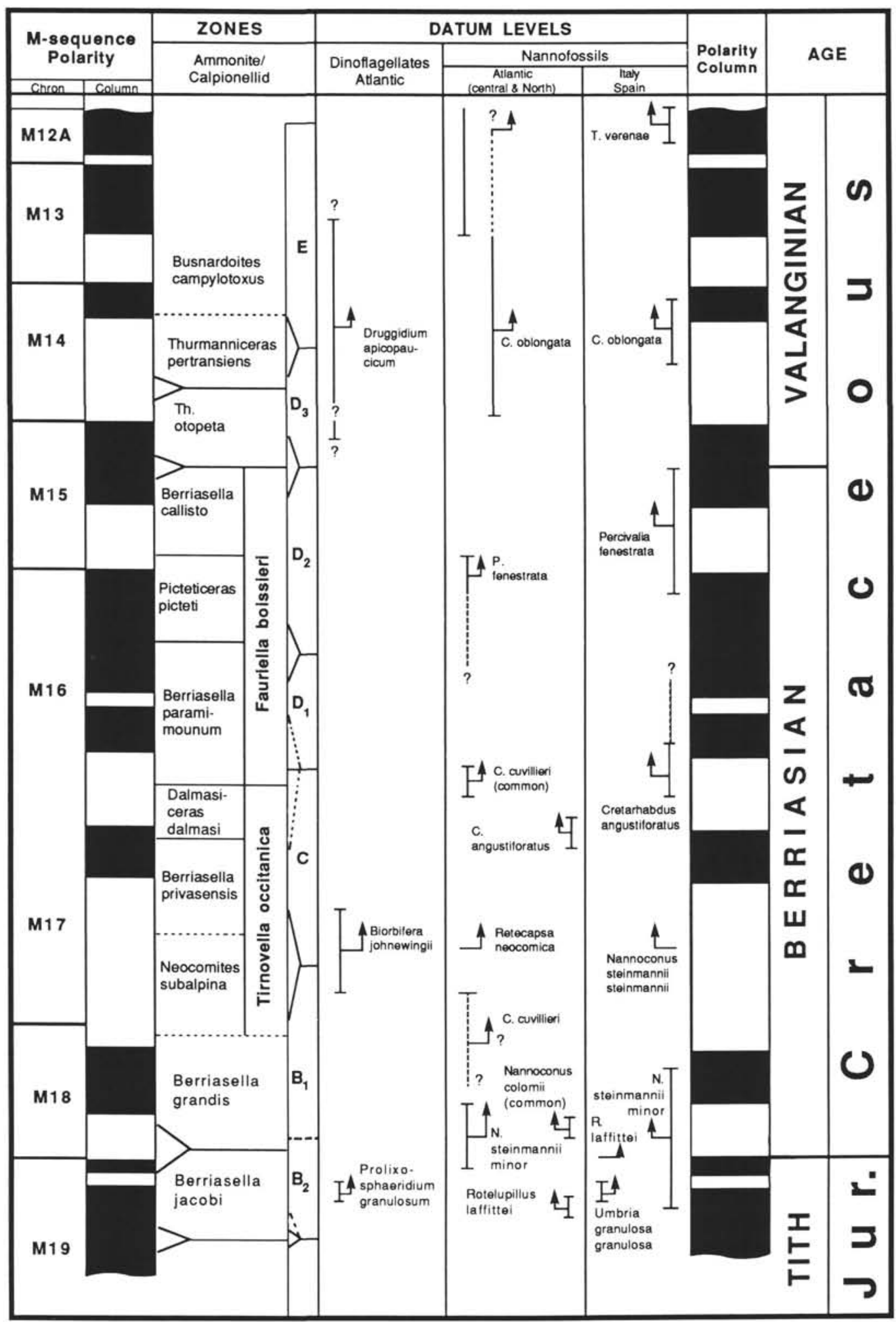

Figure 2 (continued).

scheme of Sissingh (1977) as modified by Perch-Nielsen (1979, 1985). Other nannofossil datum horizons that have been correlated to M-sequence polarity chrons (Fig. 2) are also noted on the magnetostratigraphic columns. Applegate and Bergen (this volume) discuss problems of correlating nannofossil ranges to the geological time scale.

The foraminifer biostratigraphy with the "C" zonations is by M. Moullade. In the lower Valanginian marl (Hole 639A), abun- 


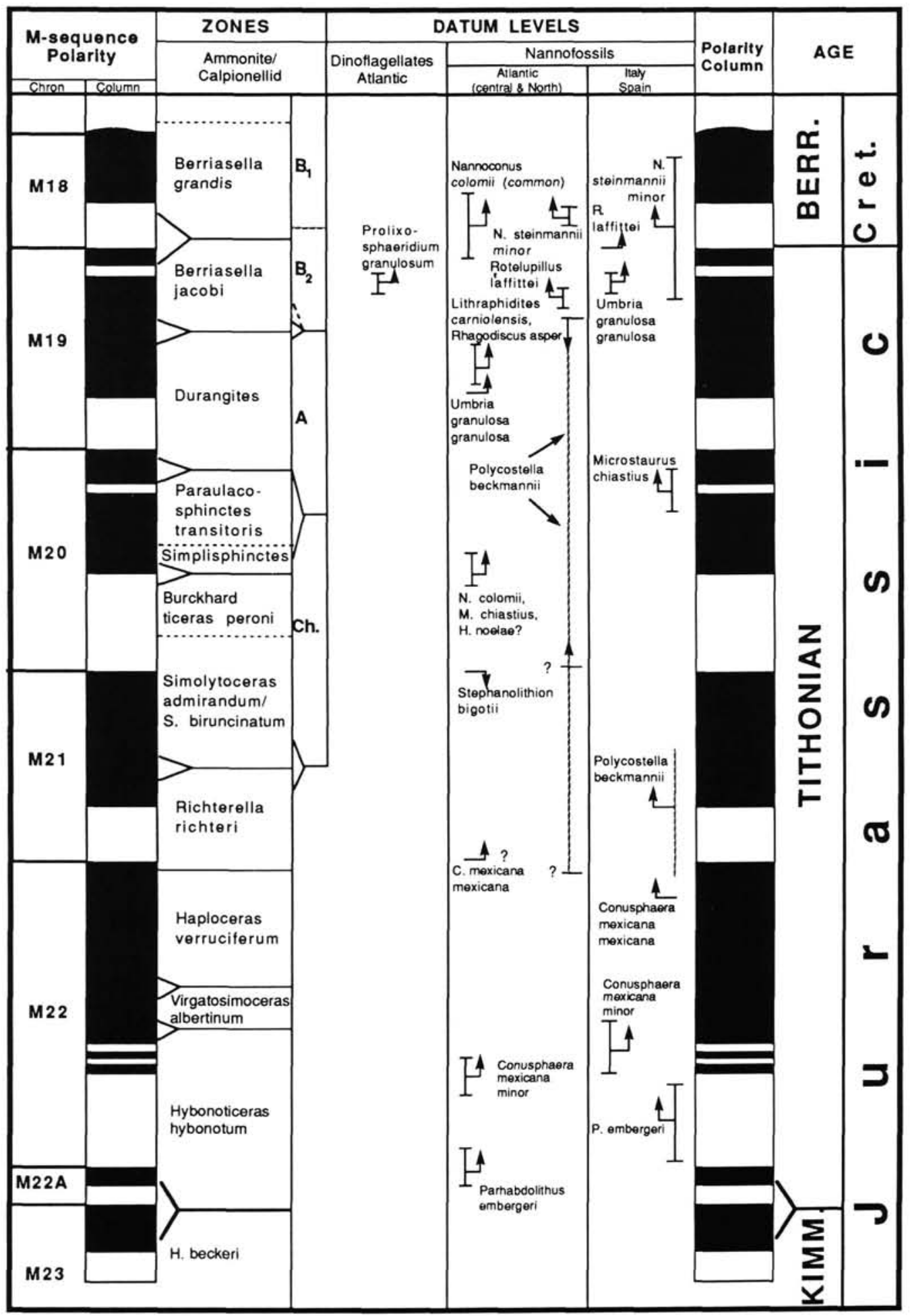

Figure 2 (continued).

dant calpionellids were identified, thereby enabling correlation to the calpionellid zonation of Remane $(1978,1983)$.

Dinoflagellate datum horizons are by Drugg and Habib (this volume) with ages based upon the zonation of Habib and Drugg (1983, 1987).

The stratigraphic position of assigned standard geological stages (e.g., Hauterivian) to the Leg 103 sediment columns varies between different biostratigraphies. This lack of interzonal agreement is a common problem in DSDP and ODP sites and probably reflects a combination of time-transgressive "datum" horizons, preservation, and inexact correlation to standard stages.

\section{ANALYTICAL METHODS AND DATA INTERPRETATION}

The laboratory and data analysis procedure is identical to that explained in detail in Ogg (1987) and will be only briefly summarized here. 


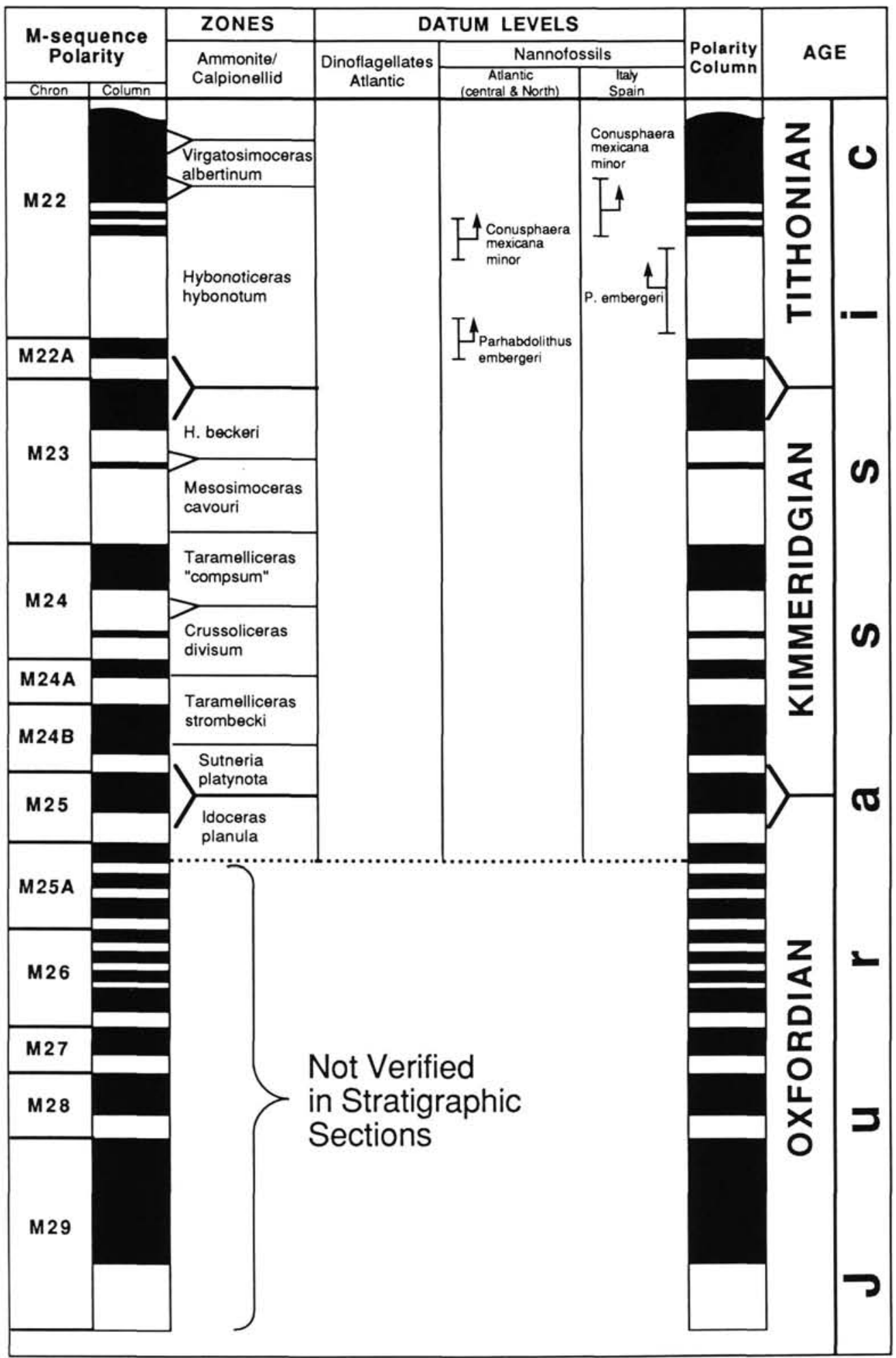

Figure 2 (continued).

\section{Sampling}

On average, three oriented paleomagnetic minicores $(2.5 \mathrm{~cm}$ diameter, 2.3 to $2.5 \mathrm{~cm}$ in length) were drilled perpendicular to the axis of the split core from each $1.5-\mathrm{m}$ section of recovered sedimentary rock. In some intervals of poorly consolidated Lower Cretaceous chalk and marl in Holes $638 \mathrm{~B}$ and $638 \mathrm{C}$, it was necessary to use oriented cubes wrapped in foil or contained in plastic boxes. Obvious slumped or disturbed intervals were avoided. If possible, the azimuth orientation of the mini- cores with respect to the direction of apparent dip of bedding (Fig. 3) was recorded and used as a "field orientation" in the data analysis.

\section{Cryogenic Magnetometer Measurements}

Paleomagnetic analyses and demagnetizations were made at the University of Wyoming in a steel-shielded room with an internal field less than 1000 nanoteslas (nT). Measurements were made on a computerlinked two-axis ScT cryogenic magnetometer using eight orientations 


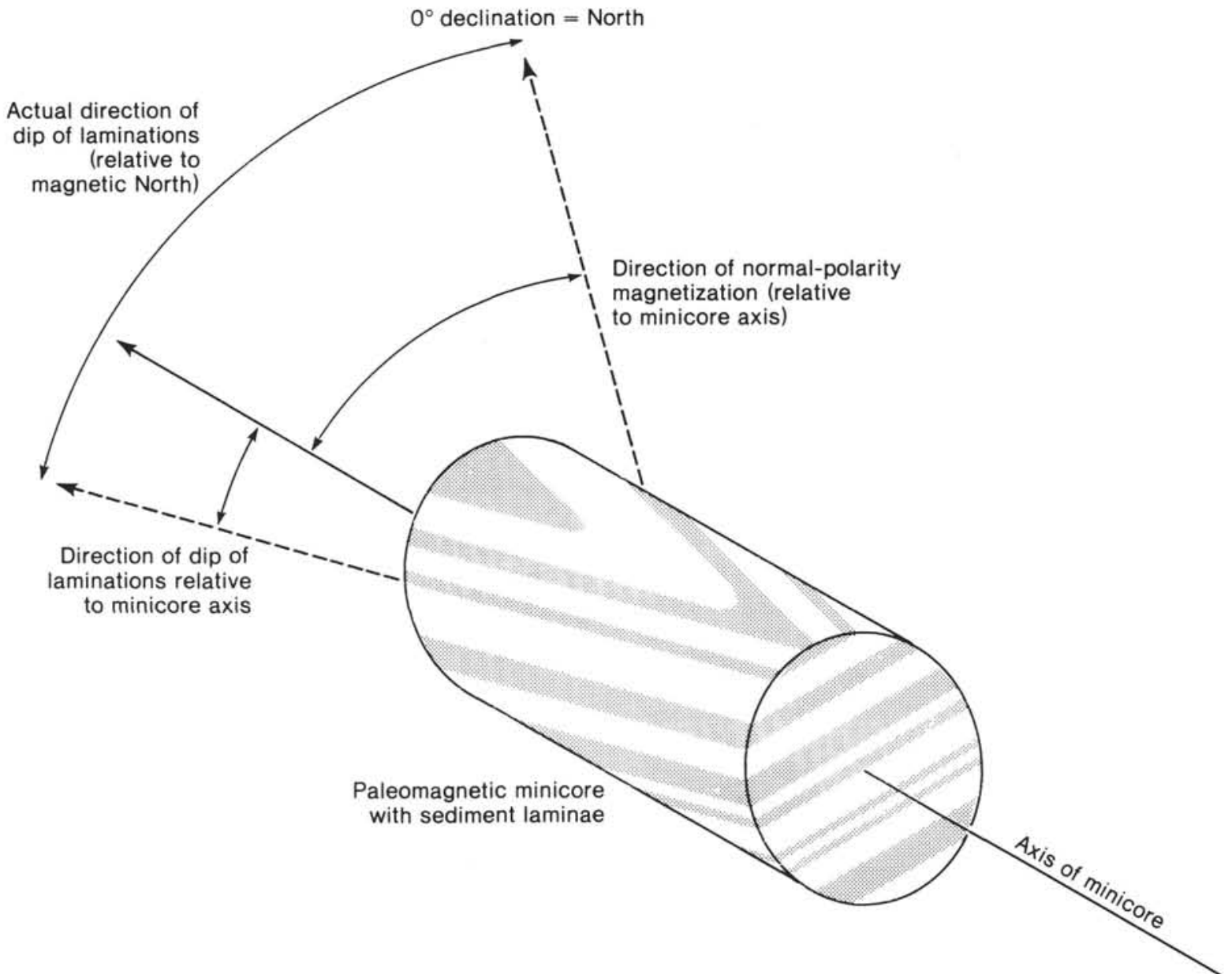

Figure 3. Orientation method for minicores using dipping laminae. The azimuth of apparent dip of the laminae relative to the axis of the minicore provides a means to orient each sample with respect to the next. This direction was used as a "field correction" on the sample orientation. The declination of normal polarity characteristic magnetization in this coordinate system (with respect to the direction of apparent dip) makes it possible to determine the azimuth of dip of the laminae with respect to paleonorth. Modified from Ogg (1987).

per sample. For magnetically weak samples, a precision of $5 \times 10^{-2}$ amperes per square meter $\left(\mathrm{Am}^{2}\right)$ on the total magnetic moment was obtained by making five 1 -s time-averaged measurements at each orientation; this is equivalent to a precision of $5 \times 10^{-7}$ amperes per meter $(\mathrm{A} / \mathrm{m})$ for a $10-\mathrm{cm}^{3}$ minicore $\left(1 \mathrm{~A} / \mathrm{m}=10^{-3} \mathrm{emu} / \mathrm{cm}^{3}=\right.$ magnetic moment per unit volume). Samples with an intensity of characteristic magnetization less than $4 \times 10^{-6} \mathrm{~A} / \mathrm{m}$ have an imprecision on the direction exceeding $25^{\circ}$; therefore, they were considered to be an unreliable indicator of polarity.

\section{Demagnetization}

All samples, except those in plastic cubes, were treated by progressive thermal demagnetization. The suite of thermal demagnetization steps varied for each lithology depending upon the results of pilot samples and the behavior of the individual samples. A minimum of initial natural remanent magnetization (NRM) plus five thermal steps in $30^{\circ}$ to $50^{\circ} \mathrm{C}$ increments was used, with many samples receiving up to eight steps. Samples in plastic cubes were treated by alternating field (AF) demagnetization at settings of both 5 and 10 milliteslas $(\mathrm{mT})$; this treatment is not considered to be as reliable as thermal demagnetization.

\section{Polarity Interpretation}

For each sample, a vector plot of the directions of magnetization during progressive demagnetization was examined to assign polarity and to identify regions of linear decay. The vector direction of the removal of present-day "northward" overprints at low demagnetization steps aided in deciphering the polarity of the samples. A conservative ap- proach was adopted in assigning polarity-if the polarity of a sample was not immediately obvious from the demagnetization behavior or the inclination of stable characteristic direction, then the polarity was assigned an interpretation of questionable polarity (N? or R? depending on whether the sample appeared to have normal or reversed polarity, respectively) or labeled INT for intermediate or indeterminate polarity. Such samples were given less weight in the magnetostratigraphy and were not used for computing paleolatitudes. Samples in which the characteristic polarity was readily apparent were denoted by NOR or REV (normal or reversed polarity, respectively) if the characteristic directions were highly stable; NOP or REP were used if the directions had poor stability, as explained in the following section.

\section{Characteristic Directions}

The direction of characteristic magnetization and associated variances were computed for each sample by applying a three-dimensional least-squares line fit to the region of stability or of univectorial decay during demagnetization (method of Kirschvink, 1980). The characteristic direction derived from this technique is a more accurate and less biased representation of the stable magnetization than a subjective selection of a "best step" direction. The intensity of characteristic magnetization is the mean of the intensities of the vectors used to calculate the characteristic magnetization.

The characteristic direction was given a "poor" rating designation, denoted by NOP or REP in the magnetostratigraphy diagrams and Appendix, if (1) the standard deviation of the least-squares fit to the removed vector was $10^{\circ}$ or greater, (2) the mean intensity was less than 8 
$\times 10^{-6} \mathrm{~A} / \mathrm{m}$, or (3) the sample lacked a region of stability and a single step was selected as indicative of the polarity. This "poor" rating generally indicates that the polarity is clearly evident but the directional stability is poor.

\section{Polarity Zones}

The polarity interpretations and reliability designations (NOR, NOP, N?, INT, R?, REP, and REV) were plotted stratigraphically. A generalized, standard-format polarity column (black = normal polarity zone, white $=$ reversed) was constructed using clusters of samples with the same polarity and including cross-hachured shading for major gaps in sampling and disruption in sedimentation. Samples having questionable (N?, R?) or indeterminate (INT) polarity interpretations were generally ignored, although there is the possibility that a concentration of samples with uncertain polarity represents a reversed polarity zone in which secondary overprints were not adequately removed. Short polarity zones based on only one sample are denoted by a short bar; these questionable events were generally ignored in correlating the magnetostratigraphy to the M-sequence.

\section{Magnetic Polarity Chron Assignments}

Assignments of magnetic polarity chrons of the M-sequence to the polarity zones for each hole were based primarily on the correlation of biostratigraphic datum levels to the magnetostratigraphy. The corresponding polarity chron was assigned from the biostratigraphic-magnetic polarity time scale in Figure 2. In most cases, it was not possible to use a direct match of the magnetic polarity pattern to an identical pattern of the $\mathrm{M}$-sequence (i.e., a fingerprint) because of the considerable variation in sedimentation rates introduced by pulses of turbidite input and possible slumping and hiatuses in parts of the sections.

\section{MAGNETIC PROPERTIES}

Four main facies comprise the recovered Upper Jurassic through Lower Cretaceous sediment sequences of the Galicia margin: Tithonian shallow-water limestone, dolomite of possible Berriasian age, lower Valanginian marl, and middle Valanginian through Aptian marl and limestone with interbedded turbidites. The results of the pilot study of the dolomite (samples from Cores 103639A-6R and 103-639A-10R) and the magnetic properties of Upper Cretaceous through Neogene sediments are given in the appropriate site chapters (Boillot, Winterer, et al., 1987).

\section{Shallow-Water Limestone (Tithonian)}

Lithologic Unit V of Site 639 is predominately light gray, bioclastic-rich, oncolitic-pelletal limestone with abundant stylolites. A suite of 56 samples was collected from Cores 103-639D$5 R$ through 103-639D-13R. Terrigeneous sand and clay are interbedded in Cores 103-639D-5R to 103-639D-8R; these clastic beds were not sampled for paleomagnetism. Magnetic intensities were weak (NRMs averaged $2 \times 10^{-4} \mathrm{~A} / \mathrm{m}$ ) and typically decreased to less than $1 \times 10^{-5} \mathrm{~A} / \mathrm{m}$ at $350^{\circ} \mathrm{C}$ demagnetization. All samples were progressively demagnetized at $50^{\circ} \mathrm{C}$ steps from $150^{\circ}$ through $400^{\circ} \mathrm{C}$; pilot samples heated through $550^{\circ} \mathrm{C}$ indicated nearly complete removal of measurable magnetization above $450^{\circ} \mathrm{C}$. A typical demagnetization plot is illustrated in Figure 4A. A sharp decline, by a factor of two, in intensity between NRM and $150^{\circ} \mathrm{C}$ was typically accompanied by a $30^{\circ}$ to $50^{\circ}$ shift in magnetic direction; the apparent randomness of this change suggests removal of a significant viscous remanent magnetization (VRM) component that had been acquired before laboratory analyses. Directions were fairly stable, with intensities steadily decreasing between $150^{\circ}$ and $400^{\circ} \mathrm{C}$.

Nearly all samples displayed normal polarity with the exception of two narrow reversed zones documented by pairs of reversed polarity samples. The reversed polarity of most of these four samples is apparent from the demagnetization behavior rather than a stable characteristic direction; therefore, there is probably a persistent normal polarity overprint on these, and probably all, samples of this lithology. The paleolatitudes derived from this sample suite are not considered reliable.

\section{Marl (Lower Valanginian)}

The pelagic sediment of lithologic Unit III of Site 639 is a mottled, soft marl to marly limestone, with colors of light yellowish gray to light grayish red to yellowish tan. A suite of 25 samples was collected from Cores 103-639A-5R through 103$639 A-8 R$. Samples in the upper part are cubes wrapped in aluminum foil; those in the lower part are minicores. NRM intensities averaged $5 \times 10^{-4} \mathrm{~A} / \mathrm{m}$ and were dominated by a normal polarity or steep downward overprint, which was largely removed upon heating above $120^{\circ} \mathrm{C}$. The intensity of reversed polarity samples increased during the first stages of thermal demagnetization. Stable characteristic directions were generally maintained during progressive thermal demagnetization from $300^{\circ}$ to $500^{\circ} \mathrm{C}$, or from $350^{\circ}$ to $600^{\circ} \mathrm{C}$ for some of the reddish-colored samples (Fig. 4B). Intensities of characteristic magnetization averaged about $2 \times 10^{-4} \mathrm{~A} / \mathrm{m}$. The stability of directions to $650^{\circ} \mathrm{C}$ for some samples indicates that hematite is one of the carriers of characteristic magnetization.

The reddish to yellowish coloration of the marl in Core 103639A-5R through the upper part of Core 103-693A-7R is partially secondary, as indicated by the gray mottling and irregular strings of tiny limonite concretions. This secondary iron oxidation is reflected in the persistence of a steep-downward, normal polarity overprint to higher demagnetization temperatures; however, the presence of gray mottles suggests that original iron minerals carrying the primary direction of magnetization are still present.

\section{Marl and Marly Limestone with Intervals of Interbedded Turbidites (Middle Valanginian through Aptian)}

The sample suites from each site are

1. Site 638, lithologic Units II and III (Valanginian-Barremian); 202 samples from Cores 103-638B-20R through 103638B-45R and 103-638C-1R through 103-638C-14R.

2. Site 640, lithologic Unit III (Hauterivian-Aptian); 21 samples from Cores 103-640A-2R-3 through 103-640A-9R.

3. Site 641, lithologic Units IV, V, and VI (Barremian-Aptian); 122 samples from Cores 103-641C-7R through 103-641C16R.

The pelagic sediment component of this suite of lithologic units consists either of gray, laminated marl or of light gray, bioturbated marly limestone; the relative proportions and cyclicity between these two structure-color end-members changes throughout the sections. Extensive intervals within these pelagic sediments are dominated by turbidite beds, both of terrigeneous clastic and of redeposited pelagic sediments. The pelagic sediment was sampled preferentially for paleomagnetism, although some samples were taken from finer-grained clastic turbidite beds at Sites 638 and 640 . The magnetic behaviors of the pelagic carbonates from all these lithologic units are similar.

Intensities of magnetization of the pelagic carbonates are very weak-NRMs were generally in the $1 \times 10^{-5}$ to $2 \times 10^{-4}$ $\mathrm{A} / \mathrm{m}$ range, and intensities of characteristic magnetizations are about half the NRM level. A downward (normal polarity?) overprint was removed upon heating above $150^{\circ} \mathrm{C}$. Stable characteristic directions were generally obtained in the $180^{\circ}$ to $300^{\circ} \mathrm{C}$ interval (Figs. 4C and 4D). The few samples of fine-grained sandstone or claystone turbidites had stronger and more stable magnetizations. Approximately one-quarter of the samples in some intervals failed to display interpretable directions. Unstable or vis- 

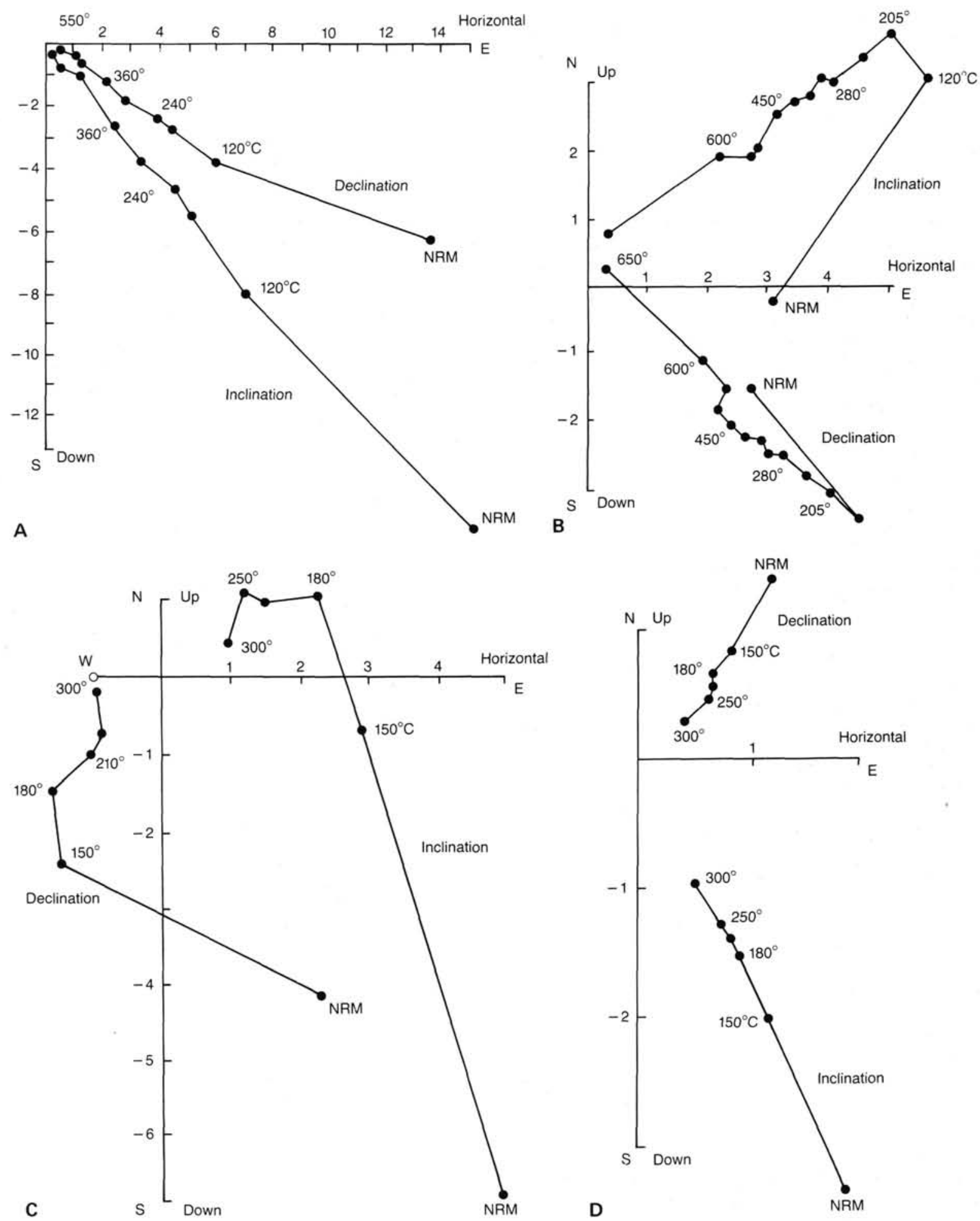

Figure 4. Vector plots of magnetic directions and intensities during thermal demagnetization of typical samples from the major lithologies of the Tithonian and Lower Cretaceous. On the vector plots, inclination (up, horizontal, down) is plotted with the total intensity of magnetization at the given demagnetization step. Declination $(\mathrm{N}, \mathrm{E}, \mathrm{S}, \mathrm{W})$ is plotted as the horizontal component of the magnetization vector; the initial (NRM) declination is arbitrary because orientation control is lacking. A. Tithonian shallow-water limestone. Sample 103-639D-10R-1, $15 \mathrm{~cm}$. Normal polarity (designated NOR), with characteristic direction obtained by leastsquares fit of the $205^{\circ}$ through $400^{\circ} \mathrm{C}$ steps $\left(1\right.$ scale division $\left.=10^{-5} \mathrm{~A} / \mathrm{m}\right)$. B. Lower Valanginian marl. Sample 103-639A-7R-1, 89 $\mathrm{cm}$. Reversed polarity (REV), with characteristic direction from $205^{\circ}$ through $600^{\circ} \mathrm{C}\left(1\right.$ scale division $\left.=10^{-4} \mathrm{~A} / \mathrm{m}\right)$. C. Lower Cretaceous bioturbated limestone. Sample 103-638B-27R-1, $56 \mathrm{~cm}$. Reversed polarity (REV), with characteristic direction from $210^{\circ}$ though $300^{\circ} \mathrm{C}\left(1\right.$ scale division $\left.=10^{-5} \mathrm{~A} / \mathrm{m}\right)$. D. Lower Cretaceous bioturbated limestone with minor lamination. Sample 103$638 \mathrm{~B}-29 \mathrm{R}-3,133 \mathrm{~cm}$. Normal polarity (NOR), with characteristic direction from $180^{\circ}$ through $300^{\circ} \mathrm{C}$. (1 scale division $=10^{-4} \mathrm{~A} / \mathrm{m}$.) 
cous magnetizations were displayed by many samples upon heating above $350^{\circ} \mathrm{C}$. The common occurrence of iron sulfides in the sediment leads to the following interpretation of this magnetic behavior: secondary overprint is carried by goethite and/ or pyrrhotite, the primary magnetization is carried by magnetite, and the high-temperature instability is introduced either by the dehydration of goethite forming hematite or by the conversion of pyrite to pyrrhotite and magnetite (Lowrie and Heller, 1982). However, other interpretations are possible.

\section{ORIENTATION OF STRUCTURAL DIPS}

In several intervals within these holes, suites of samples were oriented with respect to the direction of the $10^{\circ}$ to $20^{\circ}$ dip of the laminae and bedding in the sediments.

The Galicia margin consists of a series of north-south-trending fault blocks. Transverse seismic profiles indicate an apparent eastward dip of both the pre-rift and syn-rift sediments (Shipboard Scientific Party, 1987a; Sibuet et al., 1987; Mauffret and Montadert, this volume). Initially, it was assumed that the dip of the sediments in the drill cores was also toward the east. However, as explained in the following, the orientation of the paleomagnetic characteristic directions relative to the apparent dip direction of the sediments (Fig. 3) indicate that these sediments have a general southward dip in several of the holes.

\section{Hole 639D (Tithonian)}

The lack of laminae or bedding in the limestone precluded orienting samples with respect to structural dip. Stylolites in several cores have a dip of $15^{\circ}$ to $25^{\circ}$. Several samples (especially those in Cores 103-639D-11R and 103-639D-12R) were oriented with respect to the direction of apparent dip of adjacent stylolites. (The hole had only a $0.5^{\circ}-1^{\circ}$ measured deviation from vertical.) These oriented samples, all of which had normal polarity, yielded a fairly consistent declination. The orientation of the dip of the stylolites with respect to this "paleonorth" implies a dip toward the "southwest" (approximately $220^{\circ} \pm 50^{\circ}$ ). Whether the southwestern dip of these diagenetic features is indicative of the local structural dip, and therefore in opposition to the orientation of the regional structural trend, is debatable.

\section{Hole 639A (Lower Valanginian)}

The marly limestone in Core 103-693A-8R has abundant compacted and flattened subhorizontal burrows. This compaction-induced pseudolamination dips $30^{\circ}$ in the recovered sediments. Six minicores were oriented with respect to this apparent dip. These samples are of reversed polarity with the mean declination-hence, paleosouth-oriented approximately $80^{\circ}$ counterclockwise from the dip direction. Therefore, with respect to paleonorth, the sediment dips toward the west $\left(260^{\circ} \pm 20^{\circ}\right)$. This westward dip suggests that the hole could have been drilled into a faulted block, down dropped and back tilted with respect to the eastward regional tilt of the main structures.

\section{Hole 638B (Lower Cretaceous)}

Most samples from Cores 103-638B-21R to 103-638B-26R were oriented with respect to dipping laminae or banding. The azimuths of normal and of reversed polarity characteristic magnetizations with respect to the apparent dip are essentially random, especially in the lower cores of this interval. The abundance of slumped intervals in this portion of Hole 638B, coupled with this lack of consistent orientation, suggests that the apparent dips of laminae are primarily from local structural "cross-stratification" induced by instabilities during deposition and slope movement; therefore, dips do not reflect the regional block tilting. A few laminated samples in the uppermost cores (Cores 103-638B-21R and 103-638B-22R), which are just above the slumping, suggest that laminae in these cores may dip eastward.

\section{Hole 638C (Upper Valanginian)}

The apparent dip of laminae varied inconsistently downhole from $19^{\circ}$ to less than $5^{\circ}$, suggesting complications caused by slumping. Oriented sample suites of both normal and reversed polarity in Cores 103-638C-1R to $103-638 \mathrm{~B}-5 \mathrm{R}$ and $103-638 \mathrm{C}$ $10 \mathrm{R}$ indicate that the dips are primarily toward the south (approximately $185^{\circ} \pm 30^{\circ}$ declination with respect to paleonorth).

\section{Hole $641 \mathrm{C}$ (Barremian-Aptian)}

Over 100 samples in Cores 103-641C-8R through 103-641C$16 \mathrm{R}$ were oriented with respect to the $10^{\circ}$ to $15^{\circ}$ dip of laminae. In addition, shipboard pass-through magnetometer analyses of three pieces of split core indicated that the laminae dip azimuth has a $105^{\circ}-140^{\circ}$ declination with respect to NRM within a normal polarity interval. In normal polarity intervals, the calculated declination of the dip averages $185^{\circ}\left( \pm 20^{\circ}\right)$ with respect to paleonorth. In reversed polarity intervals, the dip declination is $175^{\circ}\left( \pm 10^{\circ}\right.$, five samples) with respect to paleonorth. Therefore, the sediments dip directly toward paleosouth.

\section{Summary}

The results of these holes indicate that the azimuth of apparent dip of bedding of most Lower Cretaceous strata is toward the paleomagnetic south pole. Iberia has rotated approximately $10^{\circ}$ counterclockwise with respect to the spin axis from the initiation of spreading in the Aptian to the present position (Vandenberg, 1980). Therefore, the azimuth of bedding in present-day coordinates would be toward the south-southeast (azimuth about $170^{\circ} \pm 10^{\circ}$ ). The apparent regional structural dip, as seen on seismic profiles, is toward the east, but this direction was generally not observed in the strata at the Leg 103 sites.

No paleolatitudes were calculated from the inclination data of the various sample sets because of the uncertainty introduced by the dipping strata and the inconsistency of the dip directions with regional tilts of blocks.

\section{MAGNETOSTRATIGRAPHY AND ASSIGNMENT OF POLARITY CHRONS}

A stratigraphic plot was prepared for each site displaying depth, core recovery, lithologic units, biostratigraphic datum levels and assignments of zones and ages, inclination and intensity of the characteristic magnetic directions (and relative "declination" with respect to an "eastward" azimuth of bedding for the oriented samples of Hole $641 \mathrm{C}$ ), and polarity interpretations of each sample (Figs. 5 through 10). These plots supersede similar plots with preliminary polarity chron assignments that appear in the site chapters (Boillot, Winterer, et al., 1987).

Variable sedimentation rates; intervals of turbidite influx; the abundance of slumps, of debris flows, and of hiatuses; and other complications preclude direct matching of the polarity patterns to the M-sequence. Assignments of polarity chrons to polarity zones were possible only by using the associated biostratigraphic datum horizons and the magnetic polarity time scale (Fig. 2). Only the interpretations of the Late Jurassic and Early Cretaceous magnetostratigraphies will be discussed; those of the younger sediments of the holes are given in the appropriate site chapters (Boillot, Winterer, et al., 1987). The majority of the polarity chron assignments are similar to the preliminary interpretations reported in Boillot, Winterer, et al., (1987); a significant revision is made for sediments of Holes $638 \mathrm{~B}$ and $638 \mathrm{C}$.

\section{Holes 638B and 638C (Valanginian-Barremian)}

The Lower Cretaceous sedimentary section at Site 638 consists of three distinct units separated by tectonic contacts that are accompanied by biostratigraphic gaps (Fig. 5). Therefore, the magnetostratigraphy of each unit must be analyzed separately. 


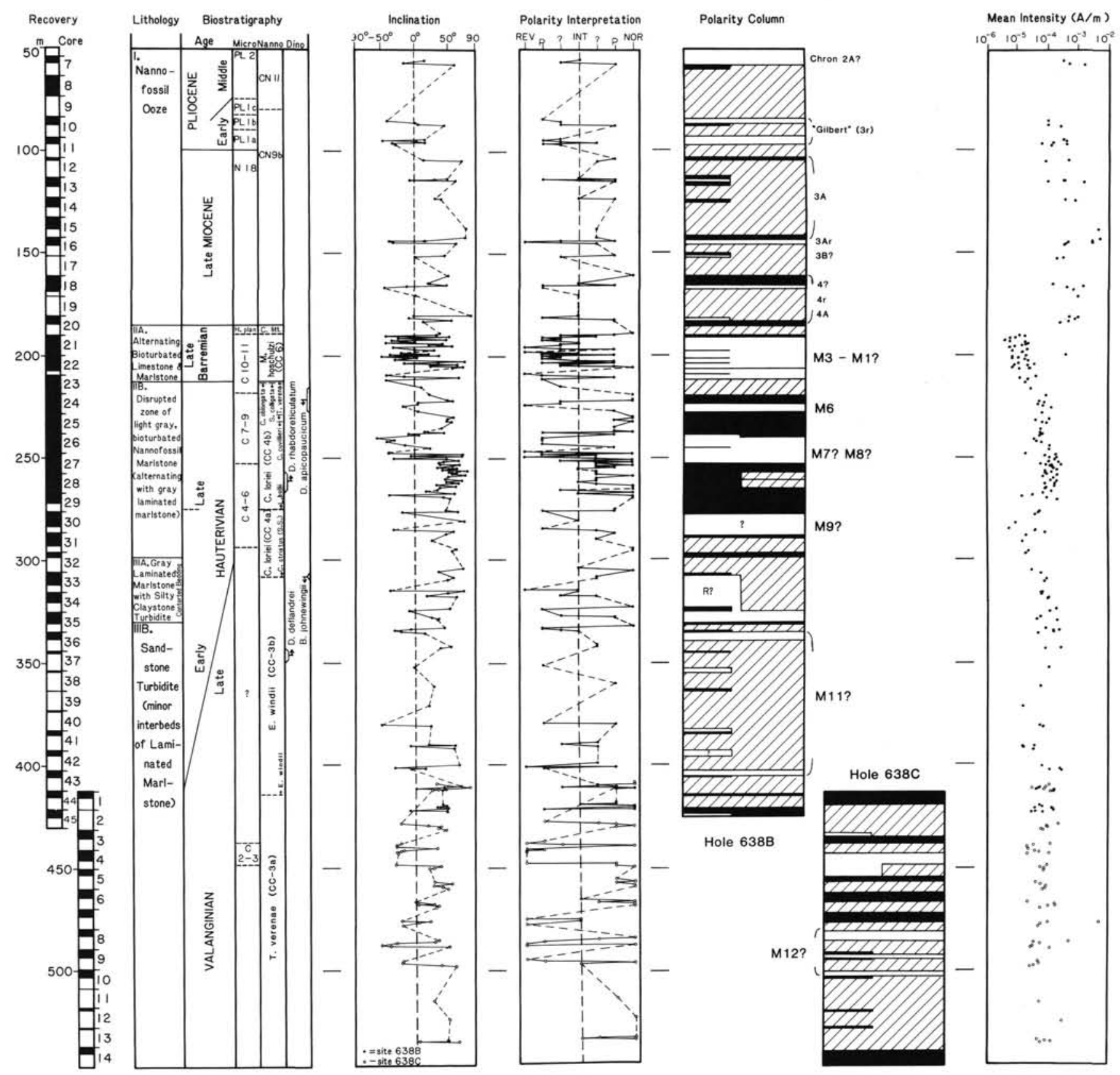

Figure 5. Early Cretaceous magnetostratigraphy of Holes 638B and 638C. Polarity interpretations are given as REV-REP-R?-INT-N?-NOP-NOR, as explained in the text, and converted to a standard polarity diagram (black = normal polarity, white $=$ reversed polarity, hachured areas $=$ gap in sampling or uncertain polarity, short bars = single sample with polarity interpretation opposite adjacent samples). Characteristic magnetization for each sample is given in the Appendix.

1. Lithologic Subunit IIA: upper Barremian cycles of bioturbated limestone and laminated marl (Samples 103-638B-20R-3, $3 \mathrm{~cm}$, to 103-638B-23R-3, $27 \mathrm{~cm})$.

This interval is predominantly reversed polarity with a few narrow normal polarity zones. It falls entirely within the $M i$ crantholithus hoschulzii (= M. obtusus) nannofossil zone (upper NC5 of western Atlantic zonation), the C9-10 foraminifer zone, and within the Odontochitina operculata dinoflagellate zone. Therefore, the reversed polarity zone could be either polarity Chron M1, M3, or both combined. The presence of reversed polarity implies that the age of this subunit is probably middle Barremian, rather than late Barremian as assigned from biostratigraphy.
Considering the apparent duration of the reversed polarity zone (it encompasses a minimum of 18 carbonate cycles), the preferred assignment is to polarity Chron M3.

2. Lithologic Subunit IIB: Hauterivian bioturbated marl with pervasive deformed bedding (Samples 103-638B-23R-3, $27 \mathrm{~cm}$, to $103-638 \mathrm{~B}-32 \mathrm{R}-2,95 \mathrm{~cm})$.

The pervasive in-situ sediment deformation suggests that "it is conceivable that all of Subunit IIB has been involved in a single, downslope movement" (Shipboard Scientific Party, 1987b). Stratigraphic order has been retained, but the coherence of the beds has been disrupted; in-situ brecciation is common. The boundary of this subunit with underlying lithologic Unit III 
corresponds to a marked change in facies, and an apparent biostratigraphic gap is suggested by the simultaneous first-appearance datum of nannofossil Calcicalathina oblongata and the last-appearance datum of dinoflagellate Biorbifera johnewingii, which indicates the possible absence of the uppermost Valanginian and lowermost Hauterivian.

The nannofossil Cruciellipsis cuvillieri last-appearance datum is just below a narrow reversed polarity zone in Core 103638B-24R (Applegate and Bergen, this volume); this datum occurs at the top of M7 in the western Central Atlantic (Ogg, 1987). However, Bralower (1987) correlated the C. cuvillieri lastappearance datum to polarity Chronozone M8 in Italian sections, but noted that Channell et al. (1979) had observed this species as high as polarity Chronozone M7 (in Bralower's reinterpretation of the magnetostratigraphy). The dinoflagellate Druggidium rhabdoreticulatum first-appearance datum is in Core 103-638B-28R; this first-appearance datum is within or just below M8 in DSDP Holes 534A and 603B (Ogg, 1987). The nannofossil $L$. bollii first-appearance datum is between Cores 103638B-29R and 103-638B-30R; this datum occurs within M9 in Italian sections (Bralower, 1987), but the species is absent in the western Atlantic. The nannofossil Tubodiscus verenae last-appearance datum is at the base of Core 103-636B-24R, but this is not considered to be a useful datum because it is occurring stratigraphically much higher than its reported uppermost range of Valanginian; in general, last-appearance datum levels are less reliable where redeposition events are present (Applegate and Bergen, this volume).

These datum levels indicate that the reversed and normal polarity zones of Cores 103-638B-29R though 103-638B-23R are within the interval of polarity Chrons M9 through M6. The assignments of M9?, M8?, and M7? are based upon the biostratigraphic control; however, these are tentative because of the possibilities of internal deformation within the block, which could have inverted strata, and of complete resetting of magnetization, which could have occurred during slumping.

3. Lithologic Unit III: Valanginian laminated marl with abundant silty-claystone and sandstone turbidites (Sample 103-638B32R-2, $95 \mathrm{~cm}$, through Core 103-638B-45R and Cores 103$638 \mathrm{C}-1 \mathrm{R}$ through $103-638 \mathrm{C}-14 \mathrm{R})$.

This unit has a rapid sedimentation rate with terrigeneous turbidites comprising over $90 \%$ of the recovered sediment of many cores, especially in lithologic Subunit IIIB. As noted above, the apparent Valanginian/Hauterivian boundary at the top of the lithologic unit is probably a biostratigraphic gap. The dinoflagellate Druggidium deflandrei first-appearance datum in Core 103-638B-37R, marking the base of the upper Valanginian (Habib and Drugg, 1983), is the only datum within the unit; this datum occurs considerably below Chronozone M10N in the western Central Atlantic (Ogg, 1987). The sediment at the base of Hole $638 \mathrm{C}$ must be younger than polarity Chron M13 (and probably younger than polarity Chron M12A), which is present in a different underlying lithology drilled at nearby Hole 639A (see the following "Hole 639A").

Based on these constraints and the extremely rapid sedimentation rate, the magnetic zones of predominantly reversed polarity were tentatively assigned to polarity Chrons M11 and M12. Polarity Chrons M10N and M10 of the latest Valanginian and early Hauterivian are, therefore, apparently absent at Site 638 because of removal by the shear plane at the base of displaced block "lithologic Subunit IIB." (These polarity chron assignments differ from preliminary interpretations in Boillot, Winterer, et al. (1987) in that (1) upper Valanginian-lower Hauterivian strata and associated polarity Chronozones M10 and M10N are now considered to be absent and (2) the basal sediments are now considered to extend into the middle Valanginian and include polarity Chronozone M12-however, these reinterpretations are also tentative.) The nannofossil Eiffellithus windii first appearance datum has been suggested as a marker for the middle Valanginian (Applegate and Bergen, this volume); this datum occurs within polarity Chronozone M11 (tentative assignment) in Hole 638B.

\section{Hole 639A (Late Early Valanginian)}

The age of the reversed polarity zone extending from the lower part of Core 103-639A-6R through Core 103-639A-8R is within Calpionellid Zone E (Fig. 6). The base of Calpionellid Zone $\mathrm{E}$ is near the top of magnetic Chronozone M14 in Italian sections (Grandesso and Channell, 1986; Channell and Grandesso, 1987). Therefore, this reversed polarity zone of Hole 639A must be polarity Chron M13. The lowest sample of Core $103-639 A-5 R$ is reversed polarity, which could represent poor recovery of the brief polarity Chron M12A.

\section{Hole 639D (Tithonian)}

The dominance of normal polarity in these cores (Fig. 7) is consistent with a middle to late Tithonian age. The identification of Calpionellid Zone A (early late Tithonian) in Core 103$639 D-5 R$ suggests that the short reversed polarity zone in the underlying Core 103-639D-6R is either polarity Chron M19 or $\mathrm{M} 2 \mathrm{O}_{\mathrm{n}-1}$. The poorly recovered, reversed polarity zone of Cores $103-639 \mathrm{D}-8 \mathrm{R}$ though $103-693 \mathrm{D}-9 \mathrm{R}$ is possibly polarity Chron M20 and/or M21.

\section{Hole 640A (Hauterivian-Aptian)}

Sparse core recovery coupled with the slow rate of sedimentation rendered the determination of a reliable magnetostratigraphy difficult (Fig. 8). Polarity chron assignments are tentative and are mainly based on the nannofossil datum horizons (dinoflagellate biostratigraphy was not available at the time this report was written). The nannofossil datum levels are all last-appearance datums, hence possibly affected by redeposition in this turbidite-rich sequence.

The sample of white chalk (103-640A-2R-2, $16 \mathrm{~cm}$ ) has reversed polarity; therefore, it could correspond to polarity Chron M0. The upper Barremian is predominantly of reversed polarity, which could correspond to polarity Chron M1 and/or upper M3 of that age. As at Site 638, the lower Barremian and the uppermost Hauterivian appear to be absent. The sparse recovery of the middle Hauterivian yielded mixed polarity, but there is inadequate detail to enable assignment of these zones to the polarity chrons between M8 and M10 of this age interval.

\section{Hole 641A (Late Cretaceous)}

There is inadequate recovery and biostratigraphic age control to justify assigning polarity chrons to the observed reversed polarity zones (Fig. 9).

\section{Hole 641C (Barremian-Aptian)}

The 10 cores (103-641C-7R through 103-641C-16R) of Aptian and Barremian age have normal polarity with a single, sharply delimited, reversed polarity zone in Core 103-641C-10R (seven samples from Samples 103-641C-10R-2, $72 \mathrm{~cm}$, to 103-641C$10 \mathrm{R}-4,59 \mathrm{~cm}$ ) (Fig. 10). The position of this reversed polarity zone just above the Barremian/Aptian boundary indicates assignment to polarity Chron M0.

Polarity Chronozone M0 occurs below the break-up unconformity associated with the seismic reflector R2 generated by the boundary between lithologic Units III and IV in Core 103641C-6R (see "Site 641" chapter; Shipboard Scientific Party, 1987 c). Magnetic surveys of the Galicia margin have tentatively identified magnetic anomaly M0 on the oceanic crust to the 


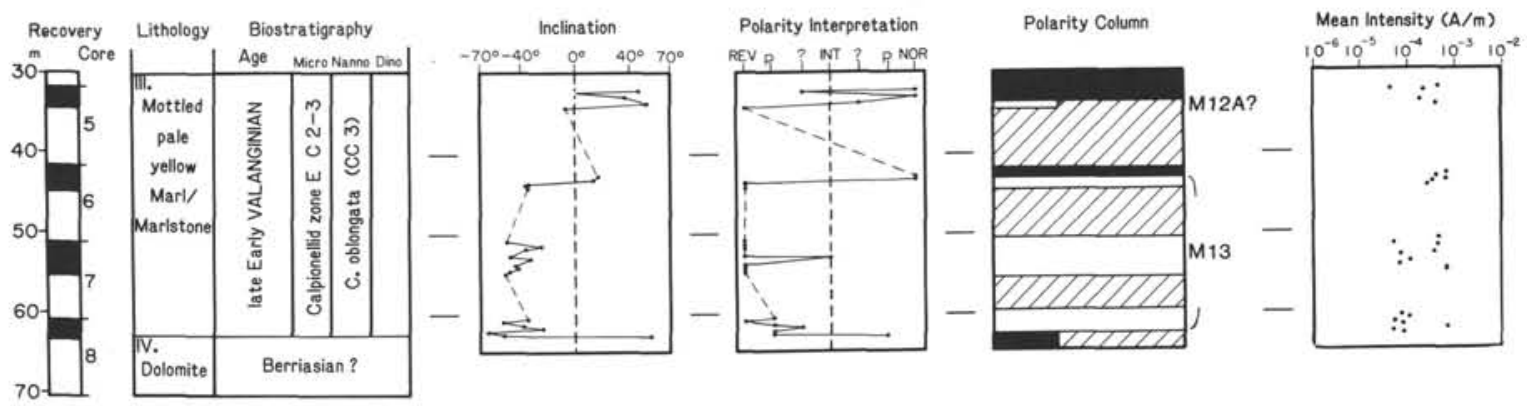

Figure 6. Early Valanginian magnetostratigraphy of Hole 639A. Polarity interpretations are given as REV-REP-R?-INT-N?NOP-NOR, as explained in the text, and converted to a standard polarity diagram (black $=$ normal polarity, white $=$ reversed polarity, hachured areas = gap in sampling or uncertain polarity, short bars = single sample with polarity interpretation opposite adjacent samples). Characteristic magnetization for each sample is given in the Appendix.

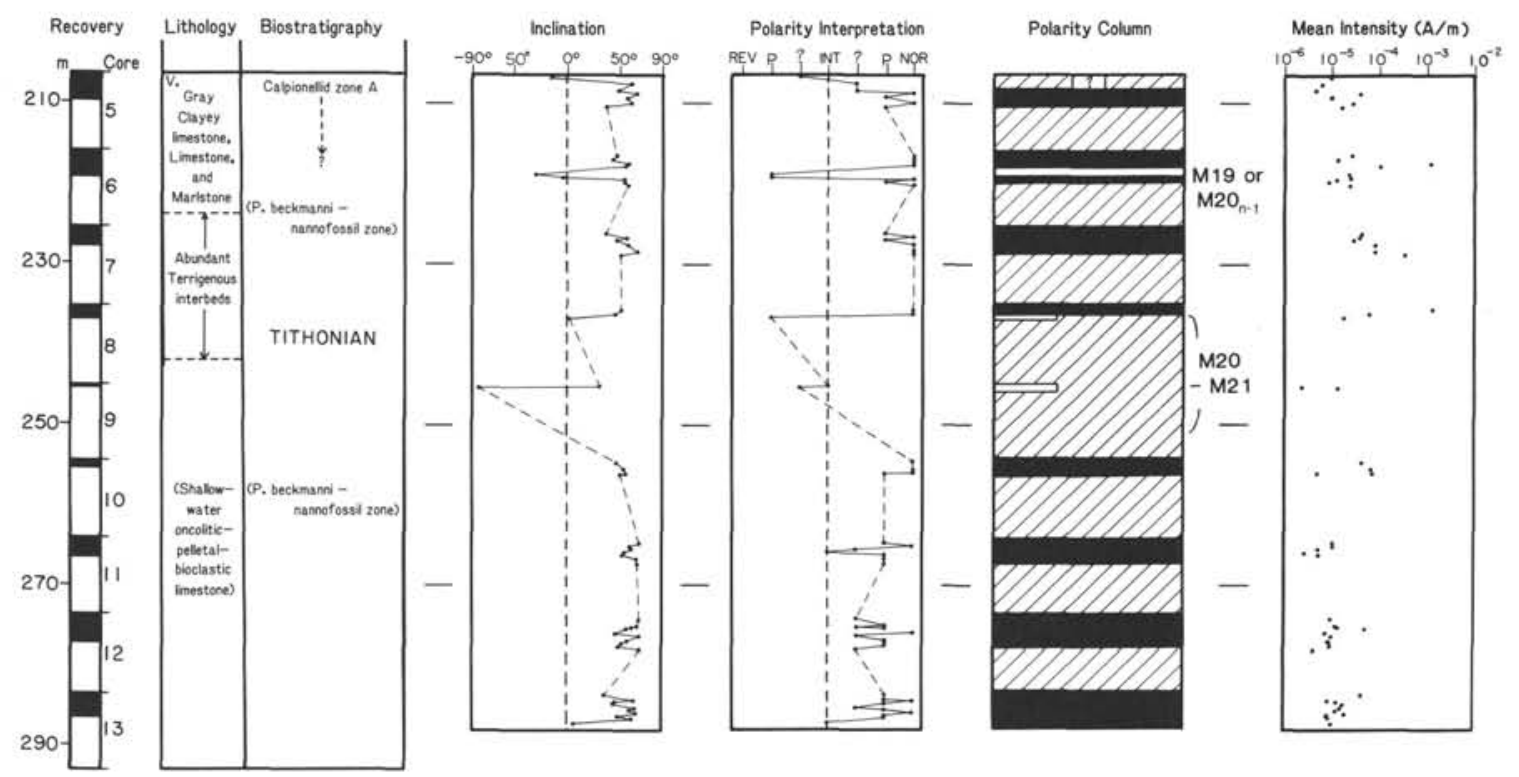

Figure 7. Tithonian magnetostratigraphy of Hole 639D. Polarity interpretations are given as REV-REP-R?-INT-N?-NOPNOR, as explained in the text, and converted to a standard polarity diagram (black $=$ normal polarity, white $=$ reversed polarity, hachured areas = gap in sampling or uncertain polarity, short bars = single sample with polarity interpretation opposite adjacent samples). Characteristic magnetization for each sample is given in the Appendix.

southwest, but not to the west of the drill sites (Verhoef et al., 1986). Therefore, there is an agreement between the anomaly patern and the results of this study: in this part of the North Atlantic, seafloor spreading propagated northward during the Early Cretaceous, and in the region west of the area drilled during Leg 103 , spreading began a few million years after the creation of the M0 anomaly.

The nannofossil Hayesites (Rucinolithus) irregularis first-appearance datum corresponds almost exactly to the Barremian/ Aptian boundary in southeastern France (Thierstein, 1971, 1973) and occurs within polarity Chron M0 in Italian magnetostratigraphic sections of Lowrie and Alvarez (1984) and Channell et al. (1979), which have nannofossil biostratigraphy by Bralower (1984, 1987). However, in Hole 641C, this datum occurs two cores below M0 and within the "Barremian" of the dinoflagellate biostratigraphy. Therefore, the nannofossil-defined "Barremian/Aptian boundary" is time-transgressive.

It is possible to estimate the degree of diachroneity of this "boundary" by using the thickness and duration of polarity Chron M0. The duration of polarity Chron M0 has been estimated as $0.62 \mathrm{~m}$.y. in the M-sequence block model (Larson and Hilde, 1975; as redated by Lowrie and Ogg, 1986). Alterna- tively, polarity Chronozone M0 in Hole $641 \mathrm{C}$ encompasses four cycles of laminated-bioturbated carbonate; if these cycles are caused by Milankovitch climatic cycles $(40,000$-yr cyclicity?), then the duration of polarity Chron M0 is approximately 0.16 $\mathrm{m} . \mathrm{y}$. These two estimates of the duration of M0 yield sedimentation rates of $0.5 \mathrm{~cm} / 1000 \mathrm{yr}$ and $2 \mathrm{~cm} / 1000 \mathrm{yr}$, respectively. The sediment facies has a gradually changing character between Core 103-641C-10R and the $H$. $(R$.) irregularis first-appearance datum in Core 103-641C-12R. Projection of a constant sedimentation rate implies that the $H$. (R.) irregularis datum occurs between 2.5 and $0.6 \mathrm{~m}$.y. prior to polarity Chron M0. These calculations indicate the possible amount of diachroneity for this datum between Italy and the Galicia margin.

Alternatively, the polarity Chronozone M0 in the Italian sections could have been displaced downward by a delayed setting of magnetization in the sediments. Magnetization carried by magnetite is set several centimeters below the sediment/water interface (post-compaction depth $=2-5 \mathrm{~cm}$ ) whereas magnetization carried by hematite has been observed to be a gradual acquisition beginning with near-surface dehydration of goethite and continuing with diagenetic growth of hematite coatings to a post-compaction depth of $60 \mathrm{~cm}$ (studies of pelagic carbonates 


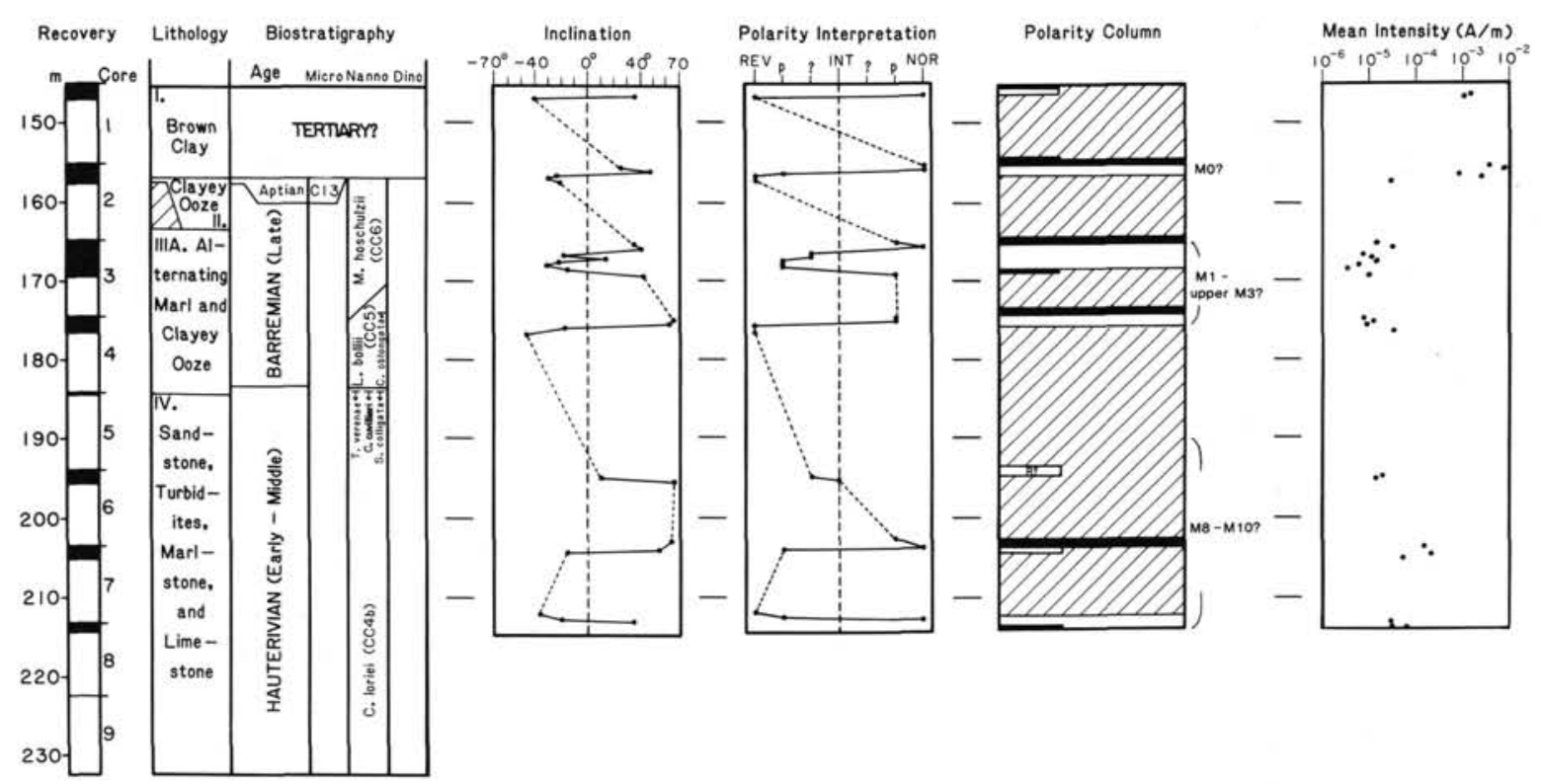

Figure 8. Early Cretaceous magnetostratigraphy of Hole 640A. Polarity interpretations are given as REV-REP-R?-INT-N?-NOPNOR, as explained in the text, and converted to a standard polarity diagram (black $=$ normal polarity, white $=$ reversed polarity, hachured areas $=$ gap in sampling or uncertain polarity, short bars $=$ single sample with polarity interpretation opposite adjacent samples). Characteristic magnetization for each sample is given in the Appendix.

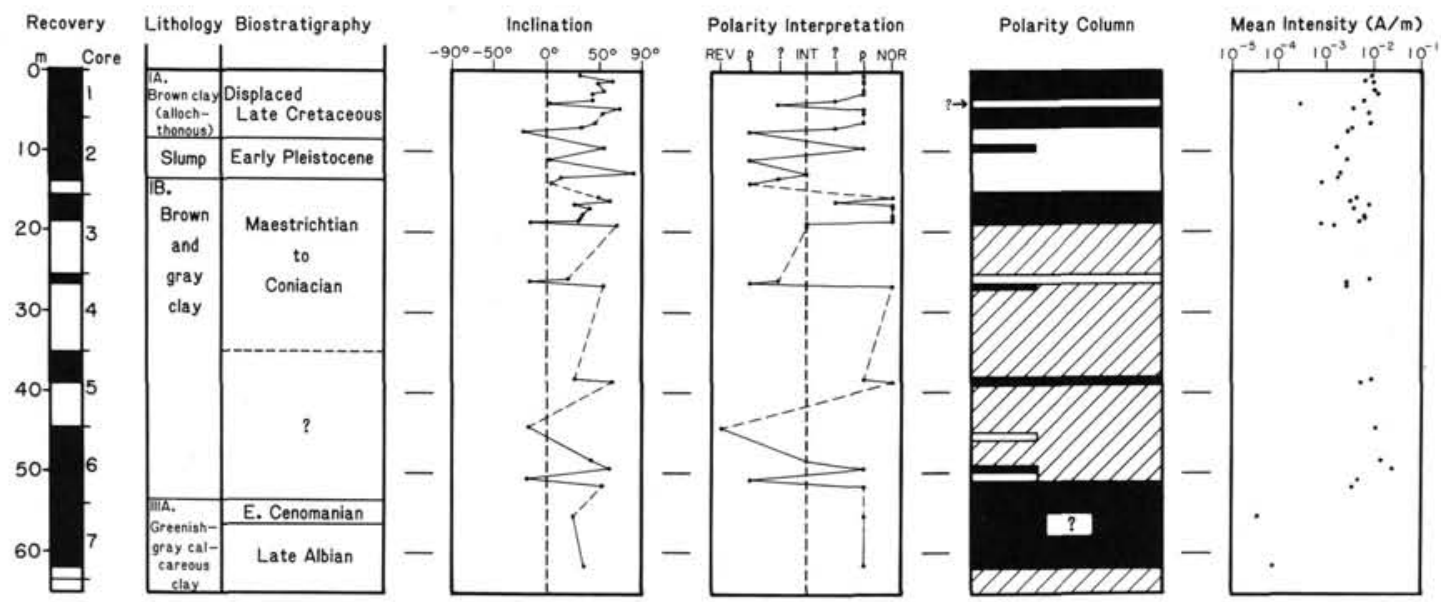

Figure 9. Tertiary magnetostratigraphy of Hole 641A. Polarity interpretations are given as REV-REP-R?-INT-N?-NOPNOR, as explained in the text, and converted to a standard polarity diagram (black $=$ normal polarity, white $=$ reversed polarity, hachured areas = gap in sampling or uncertain polarity, short bars = single sample with polarity interpretation opposite adjacent samples). Characteristic magnetization for each sample is given in the Appendix.

by Channell et al., 1982). Such a downward displacement in reversal horizons will cause a slight discrepancy in biomagnetostratigraphic correlations dependent upon the rate of sedimentation.

Hole $641 \mathrm{C}$ did not penetrate to polarity Chronozone M1 or older; therefore, the basal recovered sediments must be younger than late middle Barremian.

\section{CONCLUSIONS AND SUMMARY}

The main conclusions from the magnetostratigraphy and paleomagnetism of each hole are as follows:

1. Holes $638 \mathrm{~B}$ and $636 \mathrm{C}$ (Valanginian to Barremian). The "upper" Barremian sediments of Cores 103-638B-20R to 103638B-23R encompass the upper part of polarity Chron M3 and possibly polarity Chron M1, and therefore, are actually "middle" Barremian in age. The lower Barremian (polarity Chrons M4 and M5, and possibly M6) seems to be absent. No reliable results were obtained from the displaced Hauterivian sediments. The lowermost Hauterivian and uppermost Valanginian (polarity Chrons M10 and M10N) are absent. The Valanginian sediments were tentatively correlated to polarity Chrons M11 and M12. The drilled strata dip toward the south.

2. Hole 639A (upper lower Valanginian). The base of Core $103-639 \mathrm{~A}-5 \mathrm{R}$ is tentatively correlated to reversed polarity Chron M12A. The lower part of Core 103-639A-6R through Core 103$639 \mathrm{~A}-8 \mathrm{R}$ is the upper part of polarity Chron M13.

3. Hole 639D (Tithonian). The recovered limestone section from Cores 103-639D-5R through 103-639D-13R is probably late Tithonian in age, possibly encompassing polarity Chrons 


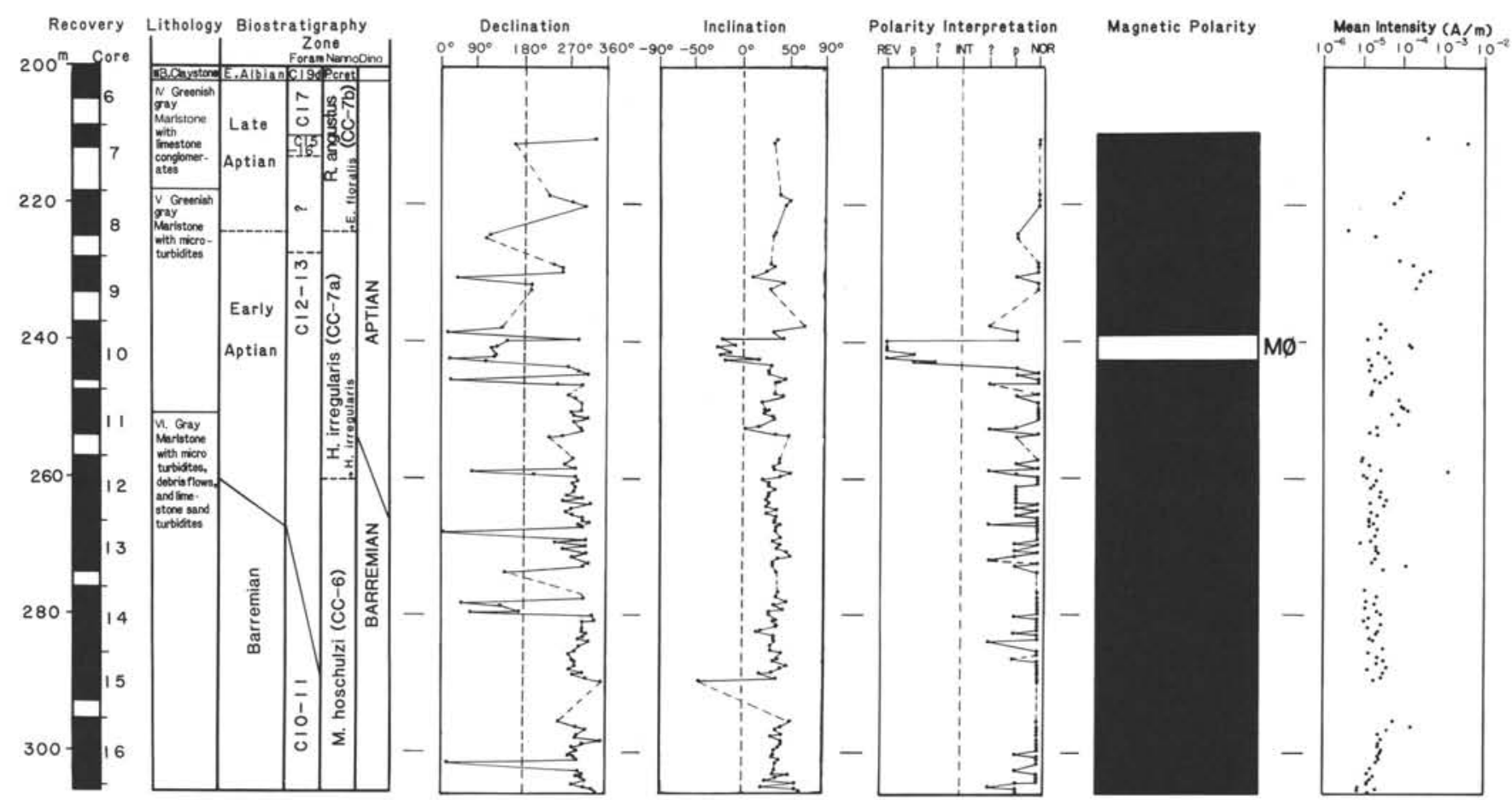

Figure 10. Early Cretaceous magnetostratigraphy of Hole 641C. Polarity interpretations are given as REV-REP-R?-INT-N?-NOP-NOR, as explained in the text, and converted to a standard polarity diagram (black = normal polarity, white $=$ reversed polarity, hachured areas $=$ gap in sampling or uncertain polarity, short bars = single sample with polarity interpretation opposite adjacent samples). Characteristic magnetization for each sample is given in the Appendix.

\section{M19, M20, and M21. Lower Tithonian (polarity Chron M22) was not penetrated.}

4. Hole $641 \mathrm{C}$ (Barremian-Aptian). Polarity Chron M0 is well documented within Core 103-641C-10R. Hole 641C did not penetrate polarity Chron M1 or older; therefore, the basal recovered sediments must be younger than late middle Barremian. Polarity Chron M0 occurs significantly above the "Barremian/ Aptian boundary" as identified by nannofossil datum horizons in Hole 641C; this relative age implies that the nannofossil datum horizons are time-transgressive between Italian sections and the Galicia margin. The preferred age assignment for polarity Chron M0 is therefore within the early Aptian; however, it may be more useful to define the Barremian/Aptian boundary as equal to the base of polarity Chron M0 for global correlation.

\section{ACKNOWLEDGMENTS}

I thank the Ocean Drilling Program of Texas A\&M University for enabling my participation on ODP Leg 103. The Leg 103 scientific party and technical staff tolerated the extensive sampling and provided valuable insights into the biostratigraphy and sediment history. Maureen Steiner and Peter Shive enabled use of the University of Wyoming cryogenic magnetometer facilities. Kathy Groff and Brigid DeVore accomplished the months of careful measurements. Timothy Bralower, Daniel Habib, and James Channell provided preprints of paleontological and magnetostratigraphic studies. Reviews of early paleomagnetic reports and drafts of this manuscript were provided by Edward Winterer, Audrey Meyer, Gilbert Boillot, Ken Kodama, and an anonymous reviewer. Financial support was provided by a grant from the U.S. Science Advisory Committee.

\section{REFERENCES}

Boillot, G., Winterer, E. L., et al., 1987. Proc. ODP, Init. Repts., 103: College Station, TX (Ocean Drilling Program).

Bralower, T. J., 1984. Biostratigraphic correlation of the Lower Cretaceous M-sequence in the Maiolica Limestone, Italy. Eos, Trans. Am. Geophys. Union, 65:865. (Abstract)
1986. Valanginian to Aptian calcareous nannofossil stratigraphy and correlation with the upper M-sequence magnetic anomalies. Mar. Micropaleontol., 11:293-310.

, in press. Calcareous nannofossil zonation of the JurassicCretaceous boundary interval and correlation with the geomagnetic polarity timescale. Mar. Micropaleontol.

Channell, J.E.T., Bralower, T. J., and Grandesso, P., 1987. Biostratigraphic correlation of M-sequence polarity Chrons M1 to M22 at Capriolo and Xausa (S. Alps, Italy). Earth Planet. Sci. Lett., 85: 203-221.

Channell, J.E.T., Freeman, R., Heller, F., and Lowrie, W., 1982. Timing of diagenetic haematite growth in red pelagic limestones from Gubbio (Italy). Earth Planet. Sci. Lett., 58:189-201.

Channell, J.E.T., and Grandesso, P., 1987. A revised correlation of magnetozones and calpionellid zones based on data from Italian pelagic limestone sections. Earth Planet. Sci. Lett., 85:222-240.

Channell, J.E.T., Lowrie, W., and Medizza, R., 1979. Middle and Early Cretaceous magnetic stratigraphy from the Cismon section, Northern Italy. Earth Planet. Sci. Lett., 42:153-166.

Cotillon, P., and Rio, M., 1984. Cyclic sedimentation in the Cretaceous of Deep Sea Drilling Project Sites 535 and 540 (Gulf of Mexico), 534 (Central Atlantic), and in the Vocontian Basin (France). In Buffler, R. T., Schlanger, W., et al., Init. Repts. DSDP, 77: Washington (U.S. Govt. Printing Office), 339-376.

Galbrun, B., 1984. Magnetostratigraphie de la limite Jurassique-Crétace. Proposition d'une echelle de polarité a partir du stratotype du Berriasien (Berrias, Ardèche, France) et de la Sierra de Lugar (Province de Murcie, Espagne) [thèse troisième cycle]. Univ. Pierre et Marie Curie, Paris, Mém. Sci. Terre, 38.

1985. Magnetostratigraphy of the Berriasian stratotype section (Berrias, France). Earth Planet. Sci. Lett., 74:130-136.

Grandesso, P., and Channell, J.E.T., 1986. A revised correlation of magnetozones and calpionellid zones based on new data from Italian pelagic limestone sections. Eos, Trans. Am. Geophys. Union, 67:265. (Abstract)

Habib, D., and Drugg, W. S., 1983. Dinoflagellate age of Middle Jurassic-Early Cretaceous sediments in the Blake-Bahama Basin. In Sheridan, R. E., Gradstein, F. M., et al., Init. Repts. DSDP, 76: Washington (U.S. Govt. Printing Office), 623-638. 
1987. Palynology of Sites 603 and 605, Leg 93, Deep Sea Drilling Project. In van Hinte, J. E., Wise, S. W., Jr., et al., Init. Repts. DSDP, 93: Washington (U.S. Govt. Printing Office), 751775.

Harland, W. B., Cox, A. V., Llewellyn, P. G., Pideton, C.A.G., Smith, A. G., and Walters, R., 1982. A Geologic Time Scale: Cambridge (Cambridge Univ. Press).

IUGS International Subcommission on Stratigraphic Classification and IUGS/IAGA Subcommission on a Magnetic Polarity Time Scale, 1979. Magnetostratigraphic polarity units-A supplementary chapter of the ISSC International Stratigraphic Guide. Geology, 7:578583.

Jansa, L. F., Enos, P., Tucholke, B. E., Gradstein, F. M., and Sheridan, R. E., 1979. Mesozoic-Cenozoic sedimentary formations of the North American Basin, western North Atlantic. In Talwani, M., Hay, W. and Ryan, W.B.F. (Eds.), Deep Drilling Results in the Atlantic Ocean: Continental Margins and Paleoenvironment. Am. Geophys. Union, Maurice Ewing Ser., 3:1-58.

Kent, D. V., and Gradstein, F. M., 1985. A Cretaceous and Jurassic geochronology. Geol. Soc. Amer. Bull., 96:1419-1427.

Kirschvink, J. L., 1980. The least-squares line and plane and the analysis of palaeomagnetic data. Geophys. J. R. Astron. Soc., 62:699718 .

Klitgord, K. D., and Schouten, H., in press. Plate kinematics of the Central Atlantic. In Tucholke, B. E., and Vogt, P. R. (Eds.), The Geology of North America: The Western Atlantic Region: Geol. Soc. Am. DNAG Series. 1:351-378.

Lancelot, Y., Hathaway, J. C., and Hollister, C. D., 1972. Lithology of sediments from the western North Atlantic. In Hollister, C. D., Ewing, J. I., et al., Init. Repts. DSDP, 11: Washington (U.S. Govt. Printing Office), 901-949.

Larson, R. L., and Hilde, T.W.C., 1975. A revised time scale of magnetic reversals for the Early Cretaceous and Late Jurassic. J. Geophys. Res., 80:2586-2594.

Lowrie, W., and Alvarez, W., 1984. Lower Cretaceous magnetic stratigraphy in Umbrian pelagic limestone sections. Earth Planet. Sci. Lett., 71:315-328.

Lowrie, W., and Channell, J.E.T., 1984. Magnetostratigraphy of the Jurassic-Cretaceous boundary in the Maiolica limestone (Umbria, Italy). Geology, 12:44-47

Lowrie, W., and Heller, F., 1962. Magnetic properties of marine limestones. Rev. Geophys. Space Phys., 20:171-192.

Lowrie, W., and Ogg, J. G., 1986. A magnetic polarity time scale for the Early Cretaceous and Late Jurassic. Earth Planet. Sci. Lett., 76: 341-349.

Marton, E., 1986. The problems of correlation between magnetozones and calpionellid zones in Late Jurassic-Early Cretaceous sections. Acta Geol. Hungarica, 29:125-131.

Ogg, J. G., 1981. Sedimentology and paleomagnetic studies of Jurassic pelagic limestones: "Ammonitico Rosso" facies [Ph.D. thesis]. Univ. California, San Diego.

1983. Magnetostratigraphy of Upper Jurassic and lowest Cretaceous sediments, Deep Sea Drillng Project Site 534, western North Atlantic. In Sheridan, R. E., Gradstein, F. M., et al., Init. Repts. DSDP, 76: Washington (U.S. Govt. Printing Office), $685-$ 697.

1987. Early Cretaceous magnetic polarity time scale and the magnetostratigraphy of Deep Sea Drilling Project Sites 603 and 534, western Central Atlantic. In van Hinte, J. E., Wise, S. W., Jr., et al., Init. Repts. DSDP, 93: Washington (U.S. Govt. Printing Office), 849-880.

Ogg, J. G., Company, M., Steiner, M. B., and Travera, J. M., 1988. Magnetostratigraphy across the Berriasian-Valanginian stage boundary (Early Cretaceous) at Cehegin (Murcia Province), Southern Spain. Earth Planet. Sci. Lett., 87:205-215.

Ogg, J. G., Haggerty, J., Sarti, M., and von Rad, U., 1987. Lower Cretaceous pelagic sediments of Deep Sea Drilling Project Site 603, western Central Atlantic: a synthesis. In van Hinte, J. E., Wise, S.
W., Jr., et al., Init. Repts. DSDP, 93: Washington (U.S. Govt. Printing Office), 1305-1332.

Ogg, J. G., and Lowrie, W., 1986. Magnetostratigraphy of the Jurassic/ Cretaceous boundary. Geology, 14:547-550.

Ogg, J. G., and Steiner, M. B., in press. Late Jurassic and Early Cretaceous magnetic polarity time scale. In Rocha, R. (Ed.), 2nd Int. Symp. Jurassic Stratigr., Lisbon, Sept. 1987.

Ogg, J. G., Steiner, M. B., Oloriz, F., and Tavera, J. M., 1984. Jurassic magnetostratigraphy, 1. Kimmeridgian-Tithonian of Sierra Gorda and Carcabuey, southern Spain. Earth Planet. Sci. Lett., 71:147-162.

Perch-Nielsen, K., 1979. Calcareous nannofossils from the Cretaceous between the North Sea and the Mediterranean. In Wiedmann, J. (Ed.), Aspekte der Kreide Europas: Int. Union Geol. Sci. Ser. A, 6: 223-272.

1985. Mesozoic calcareous nannofossils. In Bolli, H. M., Sanders, J. B., and Perch-Nielsen, K. (Eds.), Plankton Stratigraphy: Cambridge (Cambridge Univ. Press), 329-426.

Remane, J., 1978. Calpionellids. In Haq, B. U., and Boersma, A. (Eds.), Introduction to Marine Micropaleotology: New York (Elsevier), $161-170$.

1983. Calpionellids and the Jurassic/Cretaceous boundary at Deep Sea Drilling Project Site 534, western North Atlantic Ocean. In Sheridan, R. E., Gradstein, F. M., et al., Init. Repts. DSDP, 76: Washington (U.S. Govt. Printing Office), 561-567.

Schouten, H., and Klitgord, K. D., 1977. Map showing Mesozoic magnetic anomalies, western North Atlantic. Misc. Field Stud. U.S. Geol. Surv., Map MF-915.

1982. The memory of the accreting plate boundary and the continuity of fracture zones. Earth Planet. Sci. Lett., 59:255-266.

Sibuet, J.-C., Mazé, J.-P., Amortila, P., and Le Pichon, X., 1987. Physiography and structure of the western Iberian continental margin off Galicia, from Sea Beam and seismic data. In Boillot, G., Winterer, E. L., et al., Proc. ODP, Init. Repts., 103: College Station, TX (Ocean Drilling Program), 77-97.

Sissingh, W., 1977. Biostratigraphy of Cretaceous calcareous nannoplankton. Geol. Mijnbouw, 56:37-65.

Shipboard Scientific Party, 1987a. Introduction, objectives, and principal results: Ocean Drilling Program Leg 103, west Galicia margin. In Boillot, G., Winterer, E. L., et al., Proc. ODP, Init. Repts., 103: College Station, TX (Ocean Drilling Program), 3-17. 1987b. Site 638. In Boillot, G., Winterer, E. L., et al., Proc. $O D P$, Init. Repts., 103: College Station, TX (Ocean Drilling Program), 221-407.

1987c. Site 641. In Boillot, G., Winterer, E. L., et al., Proc. $O D P$, Init. Repts., 103: College Station, TX (Ocean Drilling Program), 571-649.

Sundvik, M. T., 1985. The plate tectonic framework of the western N. Atlantic Basin derived from the Keathley sequence magnetic anomaly pattern. Eos, Trans. Am. Geophys. Union, 66:368. (Abstract)

Thierstein, H. R., 1971. Tentative Lower Cretaceous nannoplankton zonation. Eclogae Geol. Helv., 64:459-468.

1973. Lower Cretaceous calcareous nannoplankton zonation. Abh. Geol. Bundesanst. (Austria), 29:1-52.

Vandenberg, J., 1980. New palaeomagnetic data from the Iberian Peninsula. Geol. Mijnbouw, 59:49-60.

Verhoef, J., Colette, B. J., Miles, P. R., Scarle, R. C., Sibuet, J.-C., and Williams, C. A., 1986. Magnetic anomalies in the northeast Atlantic Ocean. Mar. Geophys. Res., 8:1-25.

Vogt, P. R., and Einwich, A. M., 1979. Magnetic anomalies and seafloor spreading in the western North Atlantic, and a revised calibration of the Keathley (M) geomagnetic reversal chronology. In Tucholke, B. E., Vogt, P. R., et al., Init. Repts. DSDP, 43: Washington (U.S. Govt. Printing Office), 857-876.

Date of initial receipt: 7 January 1987

Date of acceptance: 1 May 1987

Ms 103B-166 


\section{APPENDIX}

Characteristic Magnetizations of Paleomagnetic Samples from ODP Leg 103

Declinations of characteristic directions are generally random owing to lack of azimuth orientation of drill cores; however, orientation of paleomagnetic samples relative to the dip direction of strata (Fig. 3) was possible in some intervals of various holes (see discussions in text). Polarity interpretations are as follows: NOR or REV = normal or reversed polarity with stable direction; NOP or REP $=$ normal or reversed polarity with less stable directions or weak intensities; N?? or R?? = questionable polarity or unstable directions; INT = indeterminate or intermediate polarity. Intensity of characteristic magnetization is the logarithmic mean of intensities of vectors used in the least-squares determination of the characteristic direction and is in units of $\mathrm{emu} / \mathrm{cm}^{3}$, where $1 \mathrm{emu} / \mathrm{cm}^{3}=10^{3} \mathrm{~A} / \mathrm{m}$.

\begin{tabular}{|c|c|c|c|c|c|}
\hline \multirow[b]{2}{*}{ Sample } & \multirow[b]{2}{*}{$\begin{array}{l}\text { Depth } \\
\text { (mbsf) }\end{array}$} & \multicolumn{4}{|c|}{ Characteristic magnetization } \\
\hline & & Declination & Inclination & Polarity & $\begin{array}{l}\text { Intensity } \\
\left(\mathrm{emu} / \mathrm{cm}^{3}\right)\end{array}$ \\
\hline $638 \mathrm{~B}-7 \mathrm{R}-1,77 \mathrm{~cm}$ & 55.17 & 92.8 & 15.3 & INT & $2.82 \times 10^{-7}$ \\
\hline $7 \mathrm{R}-2,63 \mathrm{~cm}$ & 56.53 & 225.6 & -17.2 & R?? & $4.54 \times 10^{-7}$ \\
\hline $7 \mathrm{R}-2,131 \mathrm{~cm}$ & 57.21 & 194.9 & 61.1 & NOP & $1.47 \times 10^{-6}$ \\
\hline $10 \mathrm{R}-1,92 \mathrm{~cm}$ & 85.02 & 101.6 & -39.0 & REP & $8.70 \times 10^{-8}$ \\
\hline $10 \mathrm{R}-2,146 \mathrm{~cm}$ & 87.06 & 210.6 & 6.1 & $\mathrm{R} ?$ ? & $9.02 \times 10^{-8}$ \\
\hline $10 \mathrm{R}-3,36 \mathrm{~cm}$ & 87.46 & 245.8 & 44.9 & NOP & $2.27 \times 10^{-7}$ \\
\hline $11 \mathrm{R}-1,65 \mathrm{~cm}$ & 94.35 & 87.1 & 15.5 & $\mathrm{R}$ ?? & $2.78 \times 10^{-7}$ \\
\hline $11 \mathrm{R}-1,124 \mathrm{~cm}$ & 94.94 & 48.4 & -46.6 & REP & $3.43 \times 10^{-7}$ \\
\hline $11 \mathrm{R}-2,8 \mathrm{~cm}$ & 95.28 & 354.9 & 3.4 & $\mathrm{R} ?$ ? & $1.29 \times 10^{-7}$ \\
\hline $11 \mathrm{R}-2,69 \mathrm{~cm}$ & 95.89 & 163.1 & 16.0 & N?? & $5.77 \times 10^{-8}$ \\
\hline $11 \mathrm{R}-2,108 \mathrm{~cm}$ & 96.28 & 313.2 & -33.5 & REP & $1.65 \times 10^{-7}$ \\
\hline $11 \mathrm{R}-3,8 \mathrm{~cm}$ & 96.78 & 130.4 & -27.2 & $\mathrm{R} ?$ ? & $1.13 \times 10^{-7}$ \\
\hline $12 \mathrm{R}-1,87 \mathrm{~cm}$ & 104.27 & 20.9 & 14.3 & NOP & $4.07 \times 10^{-7}$ \\
\hline $12 \mathrm{R}-1,128 \mathrm{~cm}$ & 104.68 & 44.8 & 70.6 & N?? & $7.90 \times 10^{-8}$ \\
\hline $13 \mathrm{R}-1,60 \mathrm{~cm}$ & 113.70 & 182.3 & 48.9 & INT & $2.85 \times 10^{-7}$ \\
\hline $13 \mathrm{R}-1,116 \mathrm{~cm}$ & 114.26 & 29.3 & 31.4 & NOP & $3.07 \times 10^{-7}$ \\
\hline $13 \mathrm{R}-1,130 \mathrm{~cm}$ & 114.40 & 348.0 & -7.2 & REP & $8.51 \times 10^{-8}$ \\
\hline $13 \mathrm{R}-2,24 \mathrm{~cm}$ & 114.84 & 155.9 & 61.4 & NOP & $1.36 \times 10^{-6}$ \\
\hline $14 \mathrm{R}-1,55 \mathrm{~cm}$ & 123.45 & 241.5 & 31.8 & INT & $3.12 \times 10^{-7}$ \\
\hline $14 \mathrm{R}-1,66 \mathrm{~cm}$ & 123.56 & 243.7 & 39.9 & NOP & $6.83 \times 10^{-7}$ \\
\hline $15 \mathrm{R}-4,117 \mathrm{~cm}$ & 138.27 & 304.8 & 77.7 & N?? & $3.99 \times 10^{-6}$ \\
\hline $16 \mathrm{R}-1,77 \mathrm{~cm}$ & 142.97 & 274.6 & 75.7 & N?? & $4.37 \times 10^{-6}$ \\
\hline $16 \mathrm{R}-2,69 \mathrm{~cm}$ & 144.39 & 180.0 & 16.3 & NOP & $3.77 \times 10^{-7}$ \\
\hline $16 \mathrm{R}-2,92 \mathrm{~cm}$ & 144.62 & 348.1 & -38.2 & $\mathrm{R}$ ?? & $1.10 \times 10^{-6}$ \\
\hline $16 \mathrm{R}-3,10 \mathrm{~cm}$ & 145.30 & 328.5 & -30.6 & REV & $7.68 \times 10^{-7}$ \\
\hline $16 \mathrm{R}-3,48 \mathrm{~cm}$ & 145.68 & 279.0 & 62.4 & N?? & $2.71 \times 10^{-7}$ \\
\hline $17 \mathrm{R}-1,13 \mathrm{~cm}$ & 151.93 & 36.5 & 45.8 & NOP & $2.94 \times 10^{-7}$ \\
\hline $17 \mathrm{R}-1,27 \mathrm{~cm}$ & 152.07 & 325.8 & 0.6 & R?? & $1.63 \times 10^{-7}$ \\
\hline $18 \mathrm{R}-1,22 \mathrm{~cm}$ & 161.72 & 88.2 & 51.1 & NOR & $2.25 \times 10^{-5}$ \\
\hline $18 \mathrm{R}-3,74 \mathrm{~cm}$ & 165.24 & 63.6 & 18.2 & INT & $1.30 \times 10^{-7}$ \\
\hline $18 \mathrm{R}-4,42 \mathrm{~cm}$ & 166.42 & 67.0 & 49.4 & NOP & $1.32 \times 10^{-6}$ \\
\hline $18 \mathrm{R}-4,83 \mathrm{~cm}$ & 166.83 & 106.5 & -10.7 & REP & $3.61 \times 10^{-7}$ \\
\hline $18 \mathrm{R}-5,27 \mathrm{~cm}$ & 167.77 & 283.0 & -44.7 & REP & $6.20 \times 10^{-7}$ \\
\hline $19 \mathrm{R}-1,25 \mathrm{~cm}$ & 171.35 & 147.8 & 34.0 & INT & $8.70 \times 10^{-7}$ \\
\hline $20 \mathrm{R}-1,50 \mathrm{~cm}$ & 181.10 & 352.7 & 85.6 & INT & $4.21 \times 10^{-7}$ \\
\hline $20 \mathrm{R}-1,77 \mathrm{~cm}$ & 181.37 & 311.8 & 0.4 & INT & $8.55 \times 10^{-7}$ \\
\hline $20 \mathrm{R}-2,40 \mathrm{~cm}$ & 182.50 & 8.4 & -8.2 & REP & $6.65 \times 10^{-7}$ \\
\hline $20 \mathrm{R}-2,134 \mathrm{~cm}$ & 183.44 & 17.9 & 56.4 & NOP & $3.94 \times 10^{-7}$ \\
\hline $20 \mathrm{R}-3,49 \mathrm{~cm}$ & 184.09 & 93.3 & 11.8 & NOP & $2.12 \times 10^{-6}$ \\
\hline $21 \mathrm{R}-1,14 \mathrm{~cm}$ & 190.24 & 245.6 & 40.1 & NOR & $9.99 \times 10^{-9}$ \\
\hline $21 \mathrm{R}-1,90 \mathrm{~cm}$ & 191.00 & 6.4 & 34.7 & NOP & $1.46 \times 10^{-8}$ \\
\hline $21 \mathrm{R}-1,143 \mathrm{~cm}$ & 191.53 & 260.9 & -41.6 & $\mathrm{R}$ ?? & $7.09 \times 10^{-9}$ \\
\hline $21 \mathrm{R}-2,36 \mathrm{~cm}$ & 191.96 & 46.1 & 53.4 & N?? & $4.70 \times 10^{-9}$ \\
\hline $21 \mathrm{R}-2,108 \mathrm{~cm}$ & 192.68 & 162.2 & -23.9 & REP & $3.11 \times 10^{-9}$ \\
\hline $21 \mathrm{R}-3,45 \mathrm{~cm}$ & 193.55 & 132.6 & 49.0 & $\mathrm{R}$ ?? & $4.63 \times 10^{-9}$ \\
\hline $21 \mathrm{R}-3,86 \mathrm{~cm}$ & 193.96 & 32.1 & -32.4 & REP & $1.47 \times 10^{-8}$ \\
\hline $21 \mathrm{R}-3,132 \mathrm{~cm}$ & 194.42 & 349.4 & 2.8 & R?? & $1.89 \times 10^{-8}$ \\
\hline $21 \mathrm{R}-4,30 \mathrm{~cm}$ & 194.90 & 83.1 & -41.4 & INT & $1.53 \times 10^{-8}$ \\
\hline $21 \mathrm{R}-4,67 \mathrm{~cm}$ & 195.27 & 154.4 & 42.8 & INT & $1.18 \times 10^{-8}$ \\
\hline $21 \mathrm{R}-4,104 \mathrm{~cm}$ & 195.64 & 117.1 & 22.5 & R?? & $6.76 \times 10^{-9}$ \\
\hline $21 \mathrm{R}-5,14 \mathrm{~cm}$ & 196.64 & 125.7 & 57.5 & R?? & $4.58 \times 10^{-9}$ \\
\hline $21 \mathrm{R}-5,114 \mathrm{~cm}$ & 197.24 & 142.8 & -30.1 & REV & $1.62 \times 10^{-8}$ \\
\hline $21 \mathrm{R}-6,43 \mathrm{~cm}$ & 198.03 & 222.0 & -1.1 & R?? & $5.69 \times 10^{-9}$ \\
\hline $21 \mathrm{R}-6,84 \mathrm{~cm}$ & 198.44 & 359.3 & 30.1 & NOP & $1.21 \times 10^{-8}$ \\
\hline $22 \mathrm{R}-1,27 \mathrm{~cm}$ & 199.79 & 292.9 & -18.8 & REV & $3.53 \times 10^{-7}$ \\
\hline $22 \mathrm{R}-1,65 \mathrm{~cm}$ & 200.35 & 289.3 & 22.6 & INT & $1.57 \times 10^{-8}$ \\
\hline $22 \mathrm{R}-1,108 \mathrm{~cm}$ & 200.78 & 118.4 & -34.9 & REP & $5.51 \times 10^{-9}$ \\
\hline $22 \mathrm{R}-2,7 \mathrm{~cm}$ & 201.27 & 296.3 & 37.9 & NOP & $8.72 \times 10^{-9}$ \\
\hline $22 \mathrm{R}-2,65 \mathrm{~cm}$ & 201.85 & 83.6 & -47.2 & REP & $5.24 \times 10^{-9}$ \\
\hline $22 \mathrm{R}-2,120 \mathrm{~cm}$ & 202.40 & 168.8 & 5.3 & $\mathrm{R}$ ?? & $1.47 \times 10^{-8}$ \\
\hline $22 \mathrm{R}-3,54 \mathrm{~cm}$ & 203.24 & 215.8 & -27.2 & REP & $1.87 \times 10^{-8}$ \\
\hline
\end{tabular}


Appendix (continued).

\begin{tabular}{|c|c|c|c|c|c|}
\hline \multirow[b]{2}{*}{ Sample } & \multirow[b]{2}{*}{$\begin{array}{l}\text { Depth } \\
\text { (mbsf) }\end{array}$} & \multicolumn{4}{|c|}{ Characteristic magnetization } \\
\hline & & Declination & Inclination & Polarity & $\begin{array}{l}\text { Intensity } \\
\left(\mathrm{emu} / \mathrm{cm}^{3}\right)\end{array}$ \\
\hline $22 \mathrm{R}-3,140 \mathrm{~cm}$ & 204.10 & 323.5 & 75.1 & INT & $8.73 \times 10^{-9}$ \\
\hline $22 \mathrm{R}-4,19 \mathrm{~cm}$ & 204.39 & 311.2 & 36.3 & NOP & $2.87 \times 10^{-8}$ \\
\hline $22 \mathrm{R}-4,75 \mathrm{~cm}$ & 204.95 & 238.0 & -13.3 & REP & $6.24 \times 10^{-9}$ \\
\hline $22 \mathrm{R}-4,145 \mathrm{~cm}$ & 205.65 & 122.3 & 63.9 & NOP & $1.76 \times 10^{-8}$ \\
\hline $22 \mathrm{R}-5,15 \mathrm{~cm}$ & 205.85 & 217.1 & 24.2 & R?? & $5.66 \times 10^{-9}$ \\
\hline $22 \mathrm{R}-5,74 \mathrm{~cm}$ & 206.44 & 226.1 & 28.2 & R?? & $1.95 \times 10^{-8}$ \\
\hline $22 \mathrm{R}-5,116 \mathrm{~cm}$ & 206.86 & 66.1 & 69.5 & NOP & $2.10 \times 10^{-8}$ \\
\hline $22 \mathrm{R}-6,19 \mathrm{~cm}$ & 207.30 & 323.7 & 56.0 & NOR & $9.36 \times 10^{-9}$ \\
\hline $23 \mathrm{R}-2,6 \mathrm{~cm}$ & 210.86 & 256.4 & -41.4 & REV & $3.33 \times 10^{-8}$ \\
\hline $23 \mathrm{R}-2,74 \mathrm{~cm}$ & 211.54 & 141.2 & -14.3 & REP & $9.69 \times 10^{-9}$ \\
\hline $23 \mathrm{R}-2,134 \mathrm{~cm}$ & 212.14 & 21.7 & 66.2 & NOP & $1.81 \times 10^{-8}$ \\
\hline $23 \mathrm{R}-3,9 \mathrm{~cm}$ & 212.39 & 237.4 & -40.9 & REP & $1.62 \times 10^{-8}$ \\
\hline $23 \mathrm{R}-6,6 \mathrm{~cm}$ & 216.86 & 125.4 & 11.6 & $\mathrm{R} ?$ ? & $2.20 \times 10^{-8}$ \\
\hline $24 \mathrm{R}-2,13 \mathrm{~cm}$ & 220.43 & 182.3 & 22.9 & NOR & $7.00 \times 10^{-8}$ \\
\hline $24 \mathrm{R}-3,135 \mathrm{~cm}$ & 223.15 & 152.0 & 49.1 & NOR & $4.06 \times 10^{-8}$ \\
\hline $24 \mathrm{R}-4,46 \mathrm{~cm}$ & 223.76 & 263.8 & 57.5 & NOR & $6.16 \times 10^{-8}$ \\
\hline $24 \mathrm{R}-4,121 \mathrm{~cm}$ & 224.51 & 176.4 & 6.8 & R?? & $3.89 \times 10^{-8}$ \\
\hline $24 \mathrm{R}-5,34 \mathrm{~cm}$ & 225.14 & 164.4 & 5.9 & R?? & $5.54 \times 10^{-8}$ \\
\hline $24 \mathrm{R}-6,10 \mathrm{~cm}$ & 226.27 & 358.7 & -16.0 & REV & $1.00 \times 10^{-7}$ \\
\hline $25 \mathrm{R}-1,29 \mathrm{~cm}$ & 228.69 & 320.9 & 6.1 & NOP & $5.66 \times 10^{-8}$ \\
\hline $25 \mathrm{R}-3,13 \mathrm{~cm}$ & 231.53 & 83.1 & 59.6 & NOR & $8.93 \times 10^{-8}$ \\
\hline $25 \mathrm{R}-3,75 \mathrm{~cm}$ & 232.15 & 104.0 & 50.2 & NOR & $3.15 \times 10^{-8}$ \\
\hline $25 \mathrm{R}-4,23 \mathrm{~cm}$ & 233.13 & 102.4 & 48.3 & NOP & $5.29 \times 10^{-8}$ \\
\hline $25 \mathrm{R}-4,74 \mathrm{~cm}$ & 233.64 & 345.8 & 56.3 & NOR & $7.26 \times 10^{-8}$ \\
\hline $25 \mathrm{R}-6,67 \mathrm{~cm}$ & 236.57 & 78.6 & 41.2 & NOP & $4.53 \times 10^{-8}$ \\
\hline $26 \mathrm{R}-1,31 \mathrm{~cm}$ & 238.41 & 57.4 & 15.4 & NOP & $4.52 \times 10^{-8}$ \\
\hline $26 \mathrm{R}-1,51 \mathrm{~cm}$ & 238.61 & 168.0 & 43.8 & NOR & $5.57 \times 10^{-8}$ \\
\hline $26 \mathrm{R}-1,100 \mathrm{~cm}$ & 239.10 & 117.8 & -8.2 & REP & $4.55 \times 10^{-8}$ \\
\hline $26 \mathrm{R}-2,16 \mathrm{~cm}$ & 239.76 & 101.3 & 8.2 & NO & $4.22 \times 10^{-8}$ \\
\hline $26 \mathrm{R}-3,26 \mathrm{~cm}$ & 241.36 & 173.7 & -54.1 & REP & $2.70 \times 10^{-8}$ \\
\hline $26 \mathrm{R}-3,145 \mathrm{~cm}$ & 242.55 & 272.7 & -28.0 & REP & $3.24 \times 10^{-8}$ \\
\hline $26 \mathrm{R}-4,26 \mathrm{~cm}$ & 242.86 & 14.0 & -10.7 & REP & $5.03 \times 10^{-8}$ \\
\hline $26 \mathrm{R}-5,50 \mathrm{~cm}$ & 244.60 & 311.3 & -13.3 & REP & $8.97 \times 10^{-8}$ \\
\hline $26 \mathrm{R}-6,85 \mathrm{~cm}$ & 246.45 & 146.2 & 24.0 & NOP & $9.03 \times 10^{-8}$ \\
\hline $27 \mathrm{R}-1,56 \mathrm{~cm}$ & 248.26 & 227.2 & -36.3 & REV & $1.47 \times 10^{-8}$ \\
\hline $27 \mathrm{R}-1,97 \mathrm{~cm}$ & 248.67 & 341.4 & -37.0 & REP & $1.48 \times 10^{-7}$ \\
\hline $27 \mathrm{R}-2,29 \mathrm{~cm}$ & 249.49 & 275.8 & 72.5 & NOR & $6.34 \times 10^{-8}$ \\
\hline $27 \mathrm{R}-2,78 \mathrm{~cm}$ & 249.98 & 93.6 & -6.9 & REP & $8.69 \times 10^{-8}$ \\
\hline $27 \mathrm{R}-3,18 \mathrm{~cm}$ & 250.68 & 203.2 & 71.3 & N?? & $1.60 \times 10^{-7}$ \\
\hline $27 \mathrm{R}-3,80 \mathrm{~cm}$ & 251.50 & 301.3 & -29.6 & REV & $1.32 \times 10^{-7}$ \\
\hline $27 \mathrm{R}-3,129 \mathrm{~cm}$ & 251.99 & 261.7 & 48.1 & $\mathrm{~N}$ ?? & $8.50 \times 10^{-8}$ \\
\hline $27 \mathrm{R}-4,41 \mathrm{~cm}$ & 252.61 & 264.8 & 67.0 & NOR & $1.78 \times 10^{-7}$ \\
\hline $27 \mathrm{R}-4,86 \mathrm{~cm}$ & 253.06 & 291.7 & 44.7 & R?? & $4.67 \times 10^{-8}$ \\
\hline $27 \mathrm{R}-5,12 \mathrm{~cm}$ & 253.82 & 183.1 & 36.7 & NOR & $2.16 \times 10^{-7}$ \\
\hline $27 \mathrm{R}-5,75 \mathrm{~cm}$ & 254.45 & 185.4 & 39.1 & N?? & $6.79 \times 10^{-8}$ \\
\hline $27 \mathrm{R}-5,113 \mathrm{~cm}$ & 254.83 & 358.1 & 67.9 & N?? & $1.07 \times 10^{-7}$ \\
\hline $27 \mathrm{R}-6,8 \mathrm{~cm}$ & 255.28 & 320.7 & 57.3 & NOR & $9.48 \times 10^{-8}$ \\
\hline $27 \mathrm{R}-6,88 \mathrm{~cm}$ & 256.08 & 331.6 & 34.7 & N?? & $1.11 \times 10^{-7}$ \\
\hline $27 \mathrm{R}-6,127 \mathrm{~cm}$ & 256.47 & 246.8 & $\begin{array}{l}34.1 \\
62.2\end{array}$ & N?? & $1.17 \times 10^{-7}$ \\
\hline $27 \mathrm{R}-7,8 \mathrm{~cm}$ & 256.78 & 274.1 & 54.6 & NOP & $1.57 \times 10^{-7}$ \\
\hline $27 \mathrm{R}-7,48 \mathrm{~cm}$ & 257.18 & 298.8 & 43.5 & INT & $6.14 \times 10^{-8}$ \\
\hline $27 \mathrm{R}-7,64 \mathrm{~cm}$ & 257.34 & 309.6 & 80.6 & INT & $1.10 \times 10^{-7}$ \\
\hline $28 \mathrm{R}-1,43 \mathrm{~cm}$ & 257.73 & 295.0 & 52.8 & N?? & $6.38 \times 10^{-8}$ \\
\hline $28 \mathrm{R}-1,109 \mathrm{~cm}$ & 258.39 & 228.1 & 63.1 & N?? & $7.62 \times 10^{-8}$ \\
\hline $28 \mathrm{R}-2,18 \mathrm{~cm}$ & 258.98 & 237.8 & 56.5 & N?? & $1.58 \times 10^{-7}$ \\
\hline $28 \mathrm{R}-2,97 \mathrm{~cm}$ & 259.77 & 57.7 & 76.7 & N?? & $5.47 \times 10^{-8}$ \\
\hline $28 \mathrm{R}-3,25 \mathrm{~cm}$ & 260.55 & 149.3 & 51.2 & NOR & $1.14 \times 10^{-7}$ \\
\hline $28 \mathrm{R}-3,146 \mathrm{~cm}$ & 261.76 & 123.9 & 46.7 & N?? & $1.00 \times 10^{-7}$ \\
\hline $28 \mathrm{R}-4,7 \mathrm{~cm}$ & 261.87 & 245.8 & 71.2 & N?? & $1.50 \times 10^{-7}$ \\
\hline $28 \mathrm{R}-4,116 \mathrm{~cm}$ & 262.96 & 162.5 & 49.1 & N?? & $6.33 \times 10^{-8}$ \\
\hline $28 \mathrm{R}-5,46 \mathrm{~cm}$ & 263.76 & 261.7 & 66.9 & INT & $1.29 \times 10^{-7}$ \\
\hline $28 \mathrm{R}-5,119 \mathrm{~cm}$ & 264.49 & 213.5 & 34.0 & N?? & $1.31 \times 10^{-7}$ \\
\hline $28 \mathrm{R}-6,59 \mathrm{~cm}$ & 265.39 & 38.2 & 62.0 & NOR & $6.87 \times 10^{-8}$ \\
\hline $28 \mathrm{R}-6,115 \mathrm{~cm}$ & 265.95 & 55.2 & 38.0 & NOR & $6.49 \times 10^{-8}$ \\
\hline $28 \mathrm{R}-7,40 \mathrm{~cm}$ & 266.70 & 88.0 & 35.4 & NOR & $1.03 \times 10^{-7}$ \\
\hline $29 \mathrm{R}-1,63 \mathrm{~cm}$ & 267.64 & 234.7 & 18.5 & R?? & $5.34 \times 10^{-8}$ \\
\hline $29 \mathrm{R}-2,39 \mathrm{~cm}$ & 268.89 & $\begin{array}{r}204.1 \\
3.9\end{array}$ & 60.3 & NOR & $2.59 \times 10^{-8}$ \\
\hline $29 \mathrm{R}-2,113 \mathrm{~cm}$ & 269.63 & 312.1 & $\begin{array}{r}00.5 \\
-36.7\end{array}$ & INT & $1.13 \times 10^{-8}$ \\
\hline $29 \mathrm{R}-3,63 \mathrm{~cm}$ & 270.63 & 78.2 & 35.5 & NOR & $7.22 \times 10^{-8}$ \\
\hline $29 \mathrm{R}-3,133 \mathrm{~cm}$ & 271.33 & 33.3 & 53.1 & NOR & $1.50 \times 10^{-7}$ \\
\hline $30 \mathrm{R}-1,28 \mathrm{~cm}$ & 276.98 & $\begin{array}{l}30.5 \\
77.9\end{array}$ & $\begin{array}{l}35.1 \\
37.1\end{array}$ & NOP & $3.33 \times 10^{-8}$ \\
\hline $30 \mathrm{R}-1,53 \mathrm{~cm}$ & 277.23 & 153.3 & $\begin{array}{l}37.1 \\
65.2\end{array}$ & NOP & $3.80 \times 10^{-8}$ \\
\hline $30 \mathrm{R}-1,105 \mathrm{~cm}$ & 277.75 & $\begin{array}{r}133.3 \\
37.6\end{array}$ & $\begin{array}{r}03.2 \\
-17.3\end{array}$ & REP & $3.00 \times 10^{-8}$ \\
\hline $30 \mathrm{R}-3,138 \mathrm{~cm}$ & 282.68 & $\begin{array}{r}37.0 \\
130.3\end{array}$ & $\begin{array}{r}-17.3 \\
75.0\end{array}$ & INT & $6.72 \times 10^{-9}$ \\
\hline $31 \mathrm{R}-1,35 \mathrm{~cm}$ & $\begin{array}{l}282.08 \\
286.65\end{array}$ & $\begin{array}{l}130.3 \\
160.1\end{array}$ & -29.6 & REP & $3.12 \times 10^{-8}$ \\
\hline $31 \mathrm{R}-1,129 \mathrm{~cm}$ & 287.59 & 231.9 & 59.1 & N?? & $6.38 \times 10^{-8}$ \\
\hline $31 \mathrm{R}-2,107 \mathrm{~cm}$ & 288.87 & 103.9 & 47.1 & NOP & $1.50 \times 10^{-8}$ \\
\hline
\end{tabular}


Appendix (continued).

\begin{tabular}{|c|c|c|c|c|c|}
\hline \multirow[b]{2}{*}{ Sample } & \multirow[b]{2}{*}{$\begin{array}{l}\text { Depth } \\
\text { (mbsf) }\end{array}$} & \multicolumn{4}{|c|}{ Characteristic magnetization } \\
\hline & & Declination & Inclination & Polarity & $\begin{array}{l}\text { Intensity } \\
\left(\mathrm{emu} / \mathrm{cm}^{3}\right)\end{array}$ \\
\hline $31 \mathrm{R}-3,92 \mathrm{~cm}$ & 291.72 & 39.9 & 27.0 & N?? & $1.13 \times 10^{-8}$ \\
\hline $32 \mathrm{R}-1,65 \mathrm{~cm}$ & 296.65 & 228.0 & 63.1 & NOR & $1.87 \times 10^{-8}$ \\
\hline $32 \mathrm{R}-2,77 \mathrm{~cm}$ & 297.27 & 111.0 & 57.3 & NOR & $1.49 \times 10^{-8}$ \\
\hline $33 \mathrm{R}-1,130 \mathrm{~cm}$ & 305.73 & 298.2 & 72.7 & INT & $2.38 \times 10^{-8}$ \\
\hline $33 \mathrm{R}-2,2 \mathrm{~cm}$ & 307.12 & 211.0 & 36.1 & NOR & $3.70 \times 10^{-8}$ \\
\hline $33 \mathrm{R}-3,1 \mathrm{~cm}$ & 310.11 & 117.8 & 58.7 & N?? & $7.32 \times 10^{-8}$ \\
\hline $33 \mathrm{R}-3,103 \mathrm{~cm}$ & 311.13 & 170.8 & 50.8 & $\mathrm{~N} ? ?$ & $6.25 \times 10^{-8}$ \\
\hline $34 \mathrm{R}-1,118 \mathrm{~cm}$ & 316.48 & 37.0 & -35.8 & REV & $5.31 \times 10^{-8}$ \\
\hline $34 \mathrm{R}-2,19 \mathrm{~cm}$ & 316.99 & 220.9 & 74.3 & INT & $3.89 \times 10^{-8}$ \\
\hline $34 \mathrm{R}-2,86 \mathrm{~cm}$ & 317.66 & 75.3 & 50.5 & INT & $3.90 \times 10^{-8}$ \\
\hline $34 \mathrm{R}-3,73 \mathrm{~cm}$ & 319.04 & 99.2 & 18.5 & $\mathrm{R}$ ?? & $8.97 \times 10^{-8}$ \\
\hline $34 \mathrm{R}-3,103 \mathrm{~cm}$ & 319.33 & 353.6 & 63.3 & $\mathrm{~N}$ ?? & $7.57 \times 10^{-8}$ \\
\hline $35 \mathrm{R}-1,20 \mathrm{~cm}$ & 325.10 & 206.2 & 52.8 & NOR & $1.50 \times 10^{-7}$ \\
\hline $35 \mathrm{R}-1,136 \mathrm{~cm}$ & 326.26 & 45.3 & -5.0 & REP & $9.68 \times 10^{-8}$ \\
\hline $35 \mathrm{R}-4,63 \mathrm{~cm}$ & 330.03 & 123.3 & 26.9 & $\mathrm{R}$ ?? & $3.79 \times 10^{-8}$ \\
\hline $35 \mathrm{R}-3,92 \mathrm{~cm}$ & 330.32 & 313.3 & 36.3 & NOP & $3.32 \times 10^{-8}$ \\
\hline $35 \mathrm{R}-5,3 \mathrm{~cm}$ & 330.47 & 328.6 & 34.0 & NOP & $1.33 \times 10^{-7}$ \\
\hline $36 \mathrm{R}-1,12 \mathrm{~cm}$ & 333.62 & 139.9 & 45.9 & NOR & $6.98 \times 10^{-8}$ \\
\hline $36 \mathrm{R}-1,58 \mathrm{~cm}$ & 335.08 & 198.3 & -3.2 & REP & $1.99 \times 10^{-7}$ \\
\hline $36 \mathrm{R}-2,12 \mathrm{~cm}$ & 336.12 & 263.9 & -28.8 & REP & $1.24 \times 10^{-7}$ \\
\hline $36 \mathrm{R}-2,58 \mathrm{~cm}$ & 336.58 & 42.8 & -18.3 & $\mathrm{R} ?$ ? & $1.25 \times 10^{-7}$ \\
\hline $36 \mathrm{R}-2,135 \mathrm{~cm}$ & 337.45 & 159.3 & 16.2 & INT & $3.02 \times 10^{-8}$ \\
\hline $37 \mathrm{R}-1,13 \mathrm{~cm}$ & 344.33 & 122.3 & 55.9 & N?? & $2.33 \times 10^{-7}$ \\
\hline $37 \mathrm{R}-1,55 \mathrm{~cm}$ & 343.75 & 16.2 & 39.9 & N?? & $7.08 \times 10^{-8}$ \\
\hline $38 \mathrm{R}-1,36 \mathrm{~cm}$ & 354.16 & 240.6 & 0.0 & REP & $9.44 \times 10^{-8}$ \\
\hline $39 \mathrm{R}-1,15 \mathrm{~cm}$ & 363.65 & 180.7 & 29.4 & NOP & $5.27 \times 10^{-8}$ \\
\hline $40 \mathrm{R}-1,35 \mathrm{~cm}$ & 373.45 & 168.2 & 22.8 & INT & $1.40 \times 10^{-8}$ \\
\hline $41 \mathrm{R}-1,19 \mathrm{~cm}$ & 382.99 & 188.0 & -52.7 & REP & $4.33 \times 10^{-8}$ \\
\hline $41 \mathrm{R}-1,103 \mathrm{~cm}$ & 383.83 & 307.6 & 25.4 & NOP & $6.28 \times 10^{-8}$ \\
\hline $42 \mathrm{R}-1,15 \mathrm{~cm}$ & 392.65 & 326.4 & 21.7 & N?? & $3.16 \times 10^{-8}$ \\
\hline $42 \mathrm{R}-1,45 \mathrm{~cm}$ & 392.95 & 208.7 & 60.2 & INT & $1.33 \times 10^{-8}$ \\
\hline $42 \mathrm{R}-1,145 \mathrm{~cm}$ & 393.95 & 302.4 & -6.0 & R?? & $1.37 \times 10^{-8}$ \\
\hline $42 \mathrm{R}-2,43 \mathrm{~cm}$ & 394.43 & 282.0 & 59.4 & N?? & $3.14 \times 10^{-8}$ \\
\hline $43 \mathrm{R}-1,49 \mathrm{~cm}$ & 402.69 & 109.3 & 66.2 & N?? & $6.03 \times 10^{-8}$ \\
\hline $43 \mathrm{R}-2,3 \mathrm{~cm}$ & 403.73 & 299.6 & -29.7 & REV & $2.45 \times 10^{-7}$ \\
\hline $43 \mathrm{R}-2,60 \mathrm{~cm}$ & 404.30 & 72.5 & 16.7 & NOP & $1.09 \times 10^{-7}$ \\
\hline $43 \mathrm{R}-2,75 \mathrm{~cm}$ & 404.45 & 7.2 & -5.0 & REP & $2.94 \times 10^{-7}$ \\
\hline $44 \mathrm{R}-1,121 \mathrm{~cm}$ & 413.11 & 348.4 & 69.3 & N?? & $5.38 \times 10^{-8}$ \\
\hline $44 \mathrm{R}-2,20 \mathrm{~cm}$ & 413.60 & 226.1 & 44.7 & N?? & $4.68 \times 10^{-8}$ \\
\hline $44 \mathrm{R}-2,88 \mathrm{~cm}$ & 414.28 & 247.3 & 2.0 & R?? & $4.07 \times 10^{-8}$ \\
\hline $44 \mathrm{R}-2,145 \mathrm{~cm}$ & 414.85 & 359.4 & 46.5 & NOR & $1.50 \times 10^{-7}$ \\
\hline $44 \mathrm{R}-3,15 \mathrm{~cm}$ & 415.05 & 108.5 & 41.2 & NOP & $1.48 \times 10^{-7}$ \\
\hline $45 \mathrm{R}-1,40 \mathrm{~cm}$ & 421.90 & 29.2 & 42.7 & NOP & $5.03 \times 10^{-8}$ \\
\hline $45 \mathrm{R}-1,108 \mathrm{~cm}$ & 422.58 & 25.9 & 48.0 & NOP & $6.66 \times 10^{-8}$ \\
\hline $45 \mathrm{R}-1,147 \mathrm{~cm}$ & 422.97 & 66.5 & 38.9 & INT & $3.60 \times 10^{-8}$ \\
\hline $45 \mathrm{R}-2,6 \mathrm{~cm}$ & 423.06 & 146.7 & 33.8 & NOR & $1.38 \times 10^{-7}$ \\
\hline $45 \mathrm{R}-2,47 \mathrm{~cm}$ & 423.47 & 194.5 & 50.3 & NOR & $1.50 \times 10^{-7}$ \\
\hline $45 \mathrm{R}-2,66 \mathrm{~cm}$ & 423.66 & 40.2 & 48.5 & NOR & $1.53 \times 10^{-7}$ \\
\hline $45 \mathrm{R}-3,25 \mathrm{~cm}$ & 424.75 & 324.6 & -6.1 & REP & $3.75 \times 10^{-8}$ \\
\hline $45 \mathrm{R}-3,41 \mathrm{~cm}$ & 424.91 & 86.8 & 48.7 & INT & $2.96 \times 10^{-8}$ \\
\hline $45 \mathrm{R}-3,62 \mathrm{~cm}$ & 425.12 & 215.8 & 49.3 & NOR & $6.87 \times 10^{-8}$ \\
\hline $638 \mathrm{C}-1 \mathrm{R}-1,83 \mathrm{~cm}$ & 412.73 & 264.0 & 32.5 & NOR & $1.08 \times 10^{-7}$ \\
\hline$-1 \mathrm{R}-1,128 \mathrm{~cm}$ & 413.18 & 255.6 & 50.2 & NOR & $8.10 \times 10^{-8}$ \\
\hline$-1 \mathrm{R}-2,38 \mathrm{~cm}$ & 413.78 & 200.8 & 82.9 & N?? & $3.63 \times 10^{-8}$ \\
\hline$-1 \mathrm{R}-2,130 \mathrm{~cm}$ & 414.70 & 273.8 & 35.4 & NOP & $7.38 \times 10^{-8}$ \\
\hline$-1 \mathrm{R}-3,24 \mathrm{~cm}$ & 415.14 & 321.0 & 26.3 & NOP & $1.23 \times 10^{-7}$ \\
\hline$-3 \mathrm{R}-1,19 \mathrm{~cm}$ & 431.39 & 144.0 & -21.1 & REP & $2.26 \times 10^{-7}$ \\
\hline$-3 \mathrm{R}-1,107 \mathrm{~cm}$ & 432.27 & 267.6 & 20.7 & N?? & $9.11 \times 10^{-8}$ \\
\hline$-3 \mathrm{R}-2,17 \mathrm{~cm}$ & 432.87 & 266.8 & 39.2 & NOP & $9.92 \times 10^{-8}$ \\
\hline$-3 \mathrm{R}-2,76 \mathrm{~cm}$ & 433.46 & 283.0 & 34.5 & NOR & $5.95 \times 10^{-8}$ \\
\hline$-4 \mathrm{R}-1,24 \mathrm{~cm}$ & 441.14 & 71.9 & -20.2 & REP & $1.23 \times 10^{-7}$ \\
\hline$-4 \mathrm{R}-1,110 \mathrm{~cm}$ & 442.00 & 90.0 & -26.9 & REV & $3.55 \times 10^{-8}$ \\
\hline$-4 \mathrm{R}-2,32 \mathrm{~cm}$ & 442.72 & 171.6 & -27.7 & $\mathrm{R}$ ?? & $2.22 \times 10^{-8}$ \\
\hline$-4 \mathrm{R}-2,120 \mathrm{~cm}$ & 443.60 & 238.2 & 33.5 & NOR & $2.41 \times 10^{-8}$ \\
\hline$-4 \mathrm{R}-3,58 \mathrm{~cm}$ & 444.48 & 336.2 & -16.8 & REV & $3.84 \times 10^{-8}$ \\
\hline$-4 \mathrm{R}-3,120 \mathrm{~cm}$ & 445.10 & 70.6 & -20.4 & REP & $5.53 \times 10^{-8}$ \\
\hline$-4 \mathrm{R}-4,18 \mathrm{~cm}$ & 445.58 & 54.6 & -27.5 & REV & $1.13 \times 10^{-7}$ \\
\hline$-4 \mathrm{R}-5,6 \mathrm{~cm}$ & 446.14 & 330.3 & -24.2 & REV & $2.21 \times 10^{-8}$ \\
\hline$-5 \mathrm{R}-1,136 \mathrm{~cm}$ & 451.86 & 55.9 & -28.5 & REV & $9.94 \times 10^{-8}$ \\
\hline$-5 \mathrm{R}-2,47 \mathrm{~cm}$ & 452.47 & 132.9 & 39.1 & NOP & $6.05 \times 10^{-8}$ \\
\hline$-5 \mathrm{R}-2,120 \mathrm{~cm}$ & 453.20 & 268.5 & 28.3 & NOP & $7.76 \times 10^{-8}$ \\
\hline$-5 \mathrm{R}-3,12 \mathrm{~cm}$ & 453.62 & 303.2 & 25.1 & NOR & $8.06 \times 10^{-8}$ \\
\hline$-6 \mathrm{R}-1,28 \mathrm{~cm}$ & 460.48 & 261.6 & 29.0 & NOP & $4.34 \times 10^{-8}$ \\
\hline$-6 \mathrm{R}-1,97 \mathrm{~cm}$ & 461.17 & 58.3 & 54.2 & NOR & $6.06 \times 10^{-8}$ \\
\hline$-6 \mathrm{R}-2,43 \mathrm{~cm}$ & 462.13 & 161.5 & 28.2 & NOP & $9.17 \times 10^{-8}$ \\
\hline$-6 \mathrm{R}-2,119 \mathrm{~cm}$ & 462.89 & 14.6 & 41.3 & NOR & $8.86 \times 10^{-8}$ \\
\hline$-6 \mathrm{R}-3,75 \mathrm{~cm}$ & 463.95 & 277.7 & 48.6 & NOR & $7.04 \times 10^{-8}$ \\
\hline
\end{tabular}


Appendix (continued).

\begin{tabular}{|c|c|c|c|c|c|}
\hline \multirow[b]{2}{*}{ Sample } & \multirow[b]{2}{*}{$\begin{array}{l}\text { Depth } \\
\text { (mbsf) }\end{array}$} & \multicolumn{4}{|c|}{ Characteristic magnetization } \\
\hline & & Declination & Inclination & Polarity & $\begin{array}{l}\text { Intensity } \\
\left(\mathrm{emu} / \mathrm{cm}^{3}\right)\end{array}$ \\
\hline$-7 \mathrm{R}-1,40 \mathrm{~cm}$ & 470.30 & 279.8 & 0.6 & INT & $2.30 \times 10^{-8}$ \\
\hline$-7 \mathrm{R}-1,146 \mathrm{~cm}$ & 471.36 & 326.0 & 28.4 & NOR & $1.81 \times 10^{-7}$ \\
\hline$-7 \mathrm{R}-2,18 \mathrm{~cm}$ & 471.58 & 308.0 & 4.7 & N?? & $1.91 \times 10^{-7}$ \\
\hline$-7 \mathrm{R}-2,92 \mathrm{~cm}$ & 472.32 & 62.6 & 35.1 & NOR & $1.12 \times 10^{-7}$ \\
\hline$-7 \mathrm{R}-3,25 \mathrm{~cm}$ & 473.15 & 11.0 & 32.0 & NOR & $6.05 \times 10^{-8}$ \\
\hline$-8 \mathrm{R}-1,11 \mathrm{~cm}$ & 479.61 & 195.6 & -19.7 & REV & $5.39 \times 10^{-6}$ \\
\hline$-8 \mathrm{R}-1,55 \mathrm{~cm}$ & 480.05 & 223.4 & 17.3 & INT & $1.12 \times 10^{-7}$ \\
\hline$-8 \mathrm{R}-2,40 \mathrm{~cm}$ & 481.40 & 99.1 & 5.5 & INT & $6.35 \times 10^{-8}$ \\
\hline$-8 \mathrm{R}-2,77 \mathrm{~cm}$ & 481.77 & 59.8 & -18.8 & REV & $5.52 \times 10^{-8}$ \\
\hline$-9 \mathrm{R}-1,50 \mathrm{~cm}$ & 489.70 & 76.9 & 35.1 & NOR & $5.65 \times 10^{-7}$ \\
\hline$-9 \mathrm{R}-1,114 \mathrm{~cm}$ & 490.34 & 343.6 & 29.3 & N?? & $3.80 \times 10^{-8}$ \\
\hline$-9 \mathrm{R}-2,21 \mathrm{~cm}$ & 490.91 & 54.5 & -27.8 & REP & $6.51 \times 10^{-8}$ \\
\hline$-9 \mathrm{R}-2,104 \mathrm{~cm}$ & 491.74 & 323.6 & -49.8 & REV & $3.43 \times 10^{-8}$ \\
\hline$-9 \mathrm{R}-3,10 \mathrm{~cm}$ & 492.30 & 243.0 & -36.3 & REV & $3.05 \times 10^{-8}$ \\
\hline$-9 \mathrm{R}-3,39 \mathrm{~cm}$ & 492.59 & 65.8 & 50.6 & NOR & $1.31 \times 10^{-7}$ \\
\hline$-10 \mathrm{R}-1,44 \mathrm{~cm}$ & 499.34 & 77.8 & -17.4 & REV & $5.32 \times 10^{-8}$ \\
\hline$-10 \mathrm{R}-1,113 \mathrm{~cm}$ & 500.03 & 348.6 & -19.3 & REP & $5.84 \times 10^{-8}$ \\
\hline$-10 \mathrm{R}-2,103 \mathrm{~cm}$ & 501.43 & 259.7 & 37.9 & NOR & $3.85 \times 10^{-8}$ \\
\hline$-10 \mathrm{R}-3,16 \mathrm{~cm}$ & 501.92 & 4.6 & 61.0 & INT & $3.00 \times 10^{-8}$ \\
\hline$-12 \mathrm{R}-1,80 \mathrm{~cm}$ & 519.00 & 103.0 & 27.0 & NOP & $6.35 \times 10^{-8}$ \\
\hline$-13 \mathrm{R}-1,31 \mathrm{~cm}$ & 528.21 & 205.0 & 50.4 & NOR & $3.55 \times 10^{-7}$ \\
\hline$-14 \mathrm{R}-1,97 \mathrm{~cm}$ & 538.47 & 189.7 & 47.7 & NOR & $5.61 \times 10^{-8}$ \\
\hline$-14 \mathrm{R}-1,135 \mathrm{~cm}$ & 538.85 & 335.3 & 48.0 & N?? & $1.02 \times 10^{-7}$ \\
\hline$-14 \mathrm{R}-2,25 \mathrm{~cm}$ & 539.25 & 249.2 & 5.9 & INT & $1.62 \times 10^{-7}$ \\
\hline$-14 \mathrm{R}-2,37 \mathrm{~cm}$ & 539.37 & 242.1 & 64.6 & NOR & $7.24 \times 10^{-8}$ \\
\hline 639 A-5R-1, $34 \mathrm{~cm}$ & 32.24 & 331.2 & 45.8 & NOR & $4.50 \times 10^{-7}$ \\
\hline $5 \mathrm{R}-1,62 \mathrm{~cm}$ & 32.52 & 32.6 & -0.8 & $\mathrm{R}$ ?? & $4.53 \times 10^{-8}$ \\
\hline $5 \mathrm{R}-\mathrm{I}, 127 \mathrm{~cm}$ & 33.17 & 269.2 & 38.6 & NOR & $2.21 \times 10^{-7}$ \\
\hline $5 \mathrm{R}-2,57 \mathrm{~cm}$ & 33.97 & 6.6 & 53.4 & N?? & $1.80 \times 10^{-7}$ \\
\hline $5 \mathrm{R}-2,110 \mathrm{~cm}$ & 34.50 & 325.8 & -6.3 & REV & $3.80 \times 10^{-7}$ \\
\hline $6 \mathrm{R}-2,5 \mathrm{~cm}$ & 43.15 & 212.2 & 16.9 & NOR & $6.69 \times 10^{-7}$ \\
\hline $6 \mathrm{R}-2,36 \mathrm{~cm}$ & 43.46 & 144.7 & 13.0 & NOR & $3.92 \times 10^{-7}$ \\
\hline $6 \mathrm{R}-2,69 \mathrm{~cm}$ & 43.79 & 40.2 & -33.6 & REV & $6.15 \times 10^{-7}$ \\
\hline $6 \mathrm{R}-2,98 \mathrm{~cm}$ & 44.08 & 337.1 & -36.9 & REV & $3.26 \times 10^{-7}$ \\
\hline $6 \mathrm{R}-2,145 \mathrm{~cm}$ & 44.55 & 130.5 & -35.1 & REV & $2.61 \times 10^{-7}$ \\
\hline $7 \mathrm{R}-1,14 \mathrm{~cm}$ & 51.34 & 95.0 & -50.2 & REV & $4.56 \times 10^{-7}$ \\
\hline $7 \mathrm{R}-1,53 \mathrm{~cm}$ & 51.73 & 209.8 & -23.6 & REV & $5.38 \times 10^{-8}$ \\
\hline $7 \mathrm{R}-1,89 \mathrm{~cm}$ & 52.09 & 131.2 & -35.5 & REV & $4.53 \times 10^{-7}$ \\
\hline $7 \mathrm{R}-2,40 \mathrm{~cm}$ & 53.10 & 1.2 & -48.4 & REV & $3.65 \times 10^{-7}$ \\
\hline $7 \mathrm{R}-2,70 \mathrm{~cm}$ & 53.40 & 350.7 & -32.8 & INT & $7.07 \times 10^{-8}$ \\
\hline $7 \mathrm{R}-2,142 \mathrm{~cm}$ & 54.12 & 289.0 & -43.7 & REV & $1.11 \times 10^{-7}$ \\
\hline $7 \mathrm{R}-3,7 \mathrm{~cm}$ & 54.27 & 342.8 & -42.0 & REV & $6.74 \times 10^{-8}$ \\
\hline $7 \mathrm{R}-3,63 \mathrm{~cm}$ & 54.83 & 126.6 & -48.5 & REV & $8.61 \times 10^{-7}$ \\
\hline $7 \mathrm{R}-3,118 \mathrm{~cm}$ & 55.38 & 150.4 & -51.3 & REV & $6.42 \times 10^{-7}$ \\
\hline $8 \mathrm{R}-1,17 \mathrm{~cm}$ & 60.97 & 352.9 & -35.1 & REP & $7.46 \times 10^{-8}$ \\
\hline $8 \mathrm{R}-1,56 \mathrm{~cm}$ & 61.36 & 18.1 & -51.7 & REV & $1.05 \times 10^{-7}$ \\
\hline $8 \mathrm{R}-1,93 \mathrm{~cm}$ & 61.73 & 12.0 & -38.2 & REP & $5.27 \times 10^{-8}$ \\
\hline $8 \mathrm{R}-1,139 \mathrm{~cm}$ & 62.19 & 4.1 & -23.6 & $\mathrm{R} ?$ ? & $7.64 \times 10^{-8}$ \\
\hline $8 \mathrm{R}-2,17 \mathrm{~cm}$ & 62.47 & 232.7 & -64.2 & REP & $6.73 \times 10^{-7}$ \\
\hline $8 \mathrm{R}-2,43 \mathrm{~cm}$ & 62.73 & 64.4 & -49.5 & REP & $5.05 \times 10^{-8}$ \\
\hline $8 \mathrm{R}-2,85 \mathrm{~cm}$ & 63.15 & 309.3 & 56.1 & NOP & $7.93 \times 10^{-8}$ \\
\hline $10 \mathrm{R}-1,46 \mathrm{~cm}$ & 80.56 & 168.9 & 74.4 & INT & $2.04 \times 10^{-8}$ \\
\hline 639D-5R-1, $19 \mathrm{~cm}$ & 206.69 & 350.4 & -14.6 & R?? & $1.01 \times 10^{-8}$ \\
\hline $5 \mathrm{R}-1,90 \mathrm{~cm}$ & 207.40 & 232.2 & 60.7 & N?? & $6.48 \times 10^{-9}$ \\
\hline $5 \mathrm{R}-2,9 \mathrm{~cm}$ & 208.09 & 75.3 & 48.9 & N?? & $4.77 \times 10^{-9}$ \\
\hline $5 \mathrm{R}-2,48 \mathrm{~cm}$ & 208.48 & 225.8 & 65.1 & NOR & $3.98 \times 10^{-8}$ \\
\hline $5 \mathrm{R}-2,102 \mathrm{~cm}$ & 209.02 & 308.6 & 57.6 & NOP & $9.97 \times 10^{-9}$ \\
\hline $5 \mathrm{R}-3,21 \mathrm{~cm}$ & 209.71 & 156.7 & 59.9 & NOR & $2.82 \times 10^{-8}$ \\
\hline $5 \mathrm{R}-3,70 \mathrm{~cm}$ & 210.20 & 204.6 & 37.5 & NOP & $1.68 \times 10^{-8}$ \\
\hline $6 \mathrm{R}-1,36 \mathrm{~cm}$ & 216.38 & 226.0 & 46.8 & NOR & $2.72 \times 10^{-8}$ \\
\hline $6 \mathrm{R}-1,83 \mathrm{~cm}$ & 218.83 & 248.5 & 42.8 & NOR & $1.30 \times 10^{-8}$ \\
\hline $6 \mathrm{R}-1,126 \mathrm{~cm}$ & 217.26 & 274.2 & 58.4 & NOR & $1.27 \times 10^{-6}$ \\
\hline $6 \mathrm{R}-2,14 \mathrm{~cm}$ & 217.64 & 149.4 & 55.0 & NOR & $1.03 \times 10^{-7}$ \\
\hline $6 \mathrm{R}-2,105 \mathrm{~cm}$ & 218.55 & 321.7 & -35.0 & REP & $2.27 \times 10^{-8}$ \\
\hline $6 \mathrm{R}-2,145 \mathrm{~cm}$ & 218.95 & 194.1 & -5.3 & REP & $2.37 \times 10^{-8}$ \\
\hline $6 \mathrm{R}-3,26 \mathrm{~cm}$ & 219.26 & 233.2 & 53.8 & NOR & $1.19 \times 10^{-8}$ \\
\hline $6 \mathrm{R}-3,58 \mathrm{~cm}$ & 219.58 & 348.6 & 54.7 & NOP & $8.57 \times 10^{-9}$ \\
\hline $6 \mathrm{R}-3,70 \mathrm{~cm}$ & 219.70 & 118.1 & 57.1 & NOR & $2.38 \times 10^{-8}$ \\
\hline $7 \mathrm{R}-1,23 \mathrm{~cm}$ & 225.83 & 234.5 & 37.1 & NOP & $4.07 \times 10^{-8}$ \\
\hline $7 \mathrm{R}-1,80 \mathrm{~cm}$ & 226.40 & 123.2 & 57.0 & NOR & $3.85 \times 10^{-8}$ \\
\hline $7 \mathrm{R}-1,106 \mathrm{~cm}$ & 226.66 & 174.8 & 46.2 & NOP & $2.90 \times 10^{-8}$ \\
\hline $7 \mathrm{R}-2,2 \mathrm{~cm}$ & 227.12 & 84.5 & 58.7 & NOR & $7.98 \times 10^{-8}$ \\
\hline $7 \mathrm{R}-2,99 \mathrm{~cm}$ & 228.09 & 22.4 & 67.1 & NOR & $7.89 \times 10^{-8}$ \\
\hline $7 \mathrm{R}-2,132 \mathrm{~cm}$ & 228.42 & 42.9 & 51.1 & NOR & $3.37 \times 10^{-7}$ \\
\hline $8 \mathrm{R}-1,31 \mathrm{~cm}$ & 235.51 & 82.9 & 52.1 & NOR & $1.17 \times 10^{-6}$ \\
\hline $8 \mathrm{R}-1,82 \mathrm{~cm}$ & 236.02 & 221.6 & 45.5 & NOR & $6.56 \times 10^{-8}$ \\
\hline $8 \mathrm{R}-1,135 \mathrm{~cm}$ & 236.55 & 143.2 & 2.7 & REP & $1.81 \times 10^{-8}$ \\
\hline
\end{tabular}


Appendix (continued).

\begin{tabular}{|c|c|c|c|c|c|}
\hline \multirow[b]{2}{*}{ Sample } & \multirow[b]{2}{*}{$\begin{array}{l}\text { Depth } \\
\text { (mbsf) }\end{array}$} & \multicolumn{4}{|c|}{ Characteristic magnetization } \\
\hline & & Declination & Inclination & Polarity & $\begin{array}{l}\text { Intensity } \\
\left(\mathrm{emu} / \mathrm{cm}^{3}\right)\end{array}$ \\
\hline $9 \mathrm{R}-1,10 \mathrm{~cm}$ & 245.00 & 223.0 & 30.1 & INT & $2.41 \times 10^{-9}$ \\
\hline $9 \mathrm{R}-1,23 \mathrm{~cm}$ & 245.13 & 299.7 & -84.3 & $\mathrm{R} ? ?$ & $1.36 \times 10^{-8}$ \\
\hline $10 \mathrm{R}-1,15 \mathrm{~cm}$ & 254.65 & 123.5 & 46.7 & NOR & $4.19 \times 10^{-8}$ \\
\hline $10 \mathrm{R}-1,93 \mathrm{~cm}$ & 255.43 & 271.6 & 54.5 & NOR & $6.68 \times 10^{-8}$ \\
\hline $10 \mathrm{R}-1,139 \mathrm{~cm}$ & 255.89 & 304.4 & 55.3 & NOR & $7.23 \times 10^{-8}$ \\
\hline $10 \mathrm{R}-2,5 \mathrm{~cm}$ & 256.05 & 77.1 & 51.3 & NOP & $5.26 \times 10^{-9}$ \\
\hline $11 \mathrm{R}-1,47 \mathrm{~cm}$ & 264.57 & 237.8 & 68.7 & NOP & $1.05 \times 10^{-8}$ \\
\hline $11 \mathrm{R}-1,92 \mathrm{~cm}$ & 265.02 & 298.2 & 59.2 & NOR & $1.05 \times 10^{-8}$ \\
\hline $11 \mathrm{R}-1,130 \mathrm{~cm}$ & 265.40 & 220.2 & 61.1 & N?? & $5.34 \times 10^{-9}$ \\
\hline $11 \mathrm{R}-2,18 \mathrm{~cm}$ & 265.78 & 288.3 & 54.5 & INT & $2.79 \times 10^{-9}$ \\
\hline $11 \mathrm{R}-2,42 \mathrm{~cm}$ & 266.02 & 149.8 & 52.3 & NOP & $5.39 \times 10^{-9}$ \\
\hline $11 \mathrm{R}-2,100 \mathrm{~cm}$ & 266.60 & 188.7 & 66.0 & NOP & $3.28 \times 10^{-8}$ \\
\hline $11 \mathrm{R}-3,9 \mathrm{~cm}$ & 267.19 & 206.0 & 66.8 & NOP & $8.27 \times 10^{-9}$ \\
\hline $12 \mathrm{R}-1,17 \mathrm{~cm}$ & 273.97 & 302.6 & 68.2 & N?? & $9.93 \times 10^{-9}$ \\
\hline $12 \mathrm{R}-1,98 \mathrm{~cm}$ & 274.78 & 332.0 & 66.3 & NOP & $1.22 \times 10^{-8}$ \\
\hline $12 \mathrm{R}-1,123 \mathrm{~cm}$ & 275.03 & 216.3 & 61.6 & N?? & $1.39 \times 10^{-8}$ \\
\hline $12 \mathrm{R}-2,3 \mathrm{~cm}$ & 275.33 & 260.7 & 56.5 & NOP & $6.19 \times 10^{-8}$ \\
\hline $12 \mathrm{R}-2,54 \mathrm{~cm}$ & 275.84 & 348.3 & 45.3 & NOR & $7.74 \times 10^{-9}$ \\
\hline $12 \mathrm{R}-2,92 \mathrm{~cm}$ & 276.22 & 201.9 & 68.4 & N?? & $9.76 \times 10^{-9}$ \\
\hline $12 \mathrm{R}-2,132 \mathrm{~cm}$ & 276.62 & 231.7 & 56.4 & NOP & $8.83 \times 10^{-9}$ \\
\hline $12 \mathrm{R}-3,17 \mathrm{~cm}$ & 276.97 & 216.1 & 51.6 & NOP & $9.74 \times 10^{-9}$ \\
\hline $12 \mathrm{R}-3,62 \mathrm{~cm}$ & 277.42 & 58.9 & 49.0 & NOP & $9.89 \times 10^{-9}$ \\
\hline $12 \mathrm{R}-3,97 \mathrm{~cm}$ & 277.77 & 66.6 & 69.7 & $\mathrm{~N} ? ?$ & $4.46 \times 10^{-9}$ \\
\hline $13 \mathrm{R}-1,16 \mathrm{~cm}$ & 283.56 & 120.0 & 35.1 & NOP & $4.65 \times 10^{-8}$ \\
\hline $13 \mathrm{R}-1,71 \mathrm{~cm}$ & 284.11 & 298.0 & 63.6 & NOP & $8.97 \times 10^{-9}$ \\
\hline $13 \mathrm{R}-1,95 \mathrm{~cm}$ & 284.35 & 74.4 & 46.5 & NOR & $1.31 \times 10^{-8}$ \\
\hline $13 \mathrm{R}-1,123 \mathrm{~cm}$ & 284.63 & 150.0 & 44.0 & NOP & $3.95 \times 10^{-8}$ \\
\hline $13 \mathrm{R}-2,24 \mathrm{~cm}$ & 285.14 & 224.2 & 64.9 & N?? & $1.59 \times 10^{-8}$ \\
\hline $13 \mathrm{R}-2,55 \mathrm{~cm}$ & 285.45 & 281.5 & 60.0 & NOP & $1.23 \times 10^{-8}$ \\
\hline $13 \mathrm{R}-2,98 \mathrm{~cm}$ & 285.88 & 21.2 & 65.0 & NOR & $1.92 \times 10^{-8}$ \\
\hline $13 \mathrm{R}-2,132 \mathrm{~cm}$ & 286.22 & 200.8 & 46.8 & NOP & $8.52 \times 10^{-9}$ \\
\hline $13 \mathrm{R}-3,7 \mathrm{~cm}$ & 286.47 & 270.9 & 61.1 & NOP & $8.99 \times 10^{-9}$ \\
\hline $13 \mathrm{R}-3,57 \mathrm{~cm}$ & 286.97 & 85.6 & 6.4 & INT & $9.95 \times 10^{-9}$ \\
\hline $639 \mathrm{E}-1 \mathrm{R}-1,30 \mathrm{~cm}$ & & 81.5 & 70.6 & NOR & $6.31 \times 10^{-7}$ \\
\hline $1 \mathrm{R}-1,52 \mathrm{~cm}$ & & 253.2 & -25.2 & NOR & $1.08 \times 10^{-7}$ \\
\hline $1 \mathrm{R}-1,59 \mathrm{~cm}$ & & 178.1 & 57.1 & NOR & $4.03 \times 10^{-8}$ \\
\hline $2 \mathrm{R}-1,115 \mathrm{~cm}$ & & 42.5 & 51.7 & NOR & $2.88 \times 10^{-8}$ \\
\hline $2 \mathrm{R}-1,125 \mathrm{~cm}$ & & 96.0 & 46.8 & INT & $1.53 \times 10^{-8}$ \\
\hline $639 \mathrm{~F}-1 \mathrm{R}-1,24 \mathrm{~cm}$ & & 227.9 & -15.6 & $\mathrm{R}$ ?? & $8.64 \times 10^{-7}$ \\
\hline $1 \mathrm{R}-1,108 \mathrm{~cm}$ & & 211.2 & 46.5 & INT & $6.69 \times 10^{-9}$ \\
\hline $1 \mathrm{R}-1,121 \mathrm{~cm}$ & & 282.2 & 68.8 & INT & $1.12 \times 10^{-8}$ \\
\hline $2 \mathrm{R}-1,11 \mathrm{~cm}$ & & 126.9 & -39.9 & REV & $1.28 \times 10^{-7}$ \\
\hline $640 \mathrm{~A}-1 \mathrm{R}-1,100 \mathrm{~cm}$ & 146.40 & 327.5 & 35.4 & NOR & $1.49 \times 10^{-6}$ \\
\hline $1 \mathrm{R}-1,130 \mathrm{~cm}$ & 146.70 & 91.0 & -38.0 & REV & $1.08 \times 10^{-6}$ \\
\hline $2 \mathrm{R}-1,25 \mathrm{~cm}$ & 155.35 & 103.7 & 25.0 & NOR & $3.43 \times 10^{-6}$ \\
\hline $2 \mathrm{R}-1,71 \mathrm{~cm}$ & 155.81 & 169.1 & 47.1 & NOR & $7.41 \times 10^{-6}$ \\
\hline $2 \mathrm{R}-1,130 \mathrm{~cm}$ & 156.40 & 344.9 & -22.6 & REP & $8.13 \times 10^{-7}$ \\
\hline $2 \mathrm{R}-2,18 \mathrm{~cm}$ & 156.78 & 308.7 & -28.8 & REV & $2.49 \times 10^{-6}$ \\
\hline $2 \mathrm{R}-3,11 \mathrm{~cm}$ & 157.33 & 346.9 & -20.9 & REV & $3.04 \times 10^{-8}$ \\
\hline $3 \mathrm{R}-1,45 \mathrm{~cm}$ & 165.15 & 140.8 & 35.9 & NOP & $1.45 \times 10^{-8}$ \\
\hline $3 \mathrm{R}-1,94 \mathrm{~cm}$ & 165.64 & 263.5 & 41.4 & NOR & $3.24 \times 10^{-8}$ \\
\hline $3 \mathrm{R}-2,34 \mathrm{~cm}$ & 166.54 & 165.2 & -17.2 & $\mathrm{R}$ ?? & $7.67 \times 10^{-9}$ \\
\hline $3 \mathrm{R}-2,76 \mathrm{~cm}$ & 166.96 & 192.9 & 14.4 & R?? & $1.15 \times 10^{-8}$ \\
\hline $3 \mathrm{R}-2,117 \mathrm{~cm}$ & 167.37 & 260.5 & -21.7 & REP & $1.47 \times 10^{-8}$ \\
\hline $3 \mathrm{R}-3,9 \mathrm{~cm}$ & 167.79 & 269.0 & -30.2 & REP & $6.00 \times 10^{-9}$ \\
\hline $3 \mathrm{R}-3,67 \mathrm{~cm}$ & 168.37 & 96.4 & -15.3 & REP & $3.49 \times 10^{-9}$ \\
\hline $3 \mathrm{R}-3,144 \mathrm{~cm}$ & 169.14 & 193.5 & 41.2 & NOP & $1.02 \times 10^{-8}$ \\
\hline $4 \mathrm{R}-1,24 \mathrm{~cm}$ & 174.54 & 305.4 & 64.8 & NOP & $7.85 \times 10^{-9}$ \\
\hline $4 \mathrm{R}-1,66 \mathrm{~cm}$ & 174.96 & 67.0 & 61.8 & NOP & $1.27 \times 10^{-8}$ \\
\hline $4 \mathrm{R}-1,109 \mathrm{~cm}$ & 175.39 & 252.0 & -16.9 & REV & $9.92 \times 10^{-9}$ \\
\hline $4 \mathrm{R}-2,3 \mathrm{~cm}$ & 176.17 & 261.3 & -46.4 & REV & $3.40 \times 10^{-8}$ \\
\hline $6 \mathrm{R}-1,91 \mathrm{~cm}$ & 194.61 & 96.0 & 11.2 & $\mathrm{R}$ ?? & $1.88 \times 10^{-8}$ \\
\hline $6 \mathrm{R}-1,129 \mathrm{~cm}$ & 194.99 & 66.7 & 66.8 & INT & $1.40 \times 10^{-8}$ \\
\hline $7 \mathrm{R}-1,29 \mathrm{~cm}$ & 203.59 & 180.7 & 62.9 & NOP & $1.49 \times 10^{-7}$ \\
\hline $7 \mathrm{R}-1,135 \mathrm{~cm}$ & 204.65 & 2.8 & 54.8 & NOR & $2.08 \times 10^{-7}$ \\
\hline $7 \mathrm{R}-2,10 \mathrm{~cm}$ & 205.03 & 98.5 & -15.6 & REP & $5.14 \times 10^{-8}$ \\
\hline $8 \mathrm{R}-1,5 \mathrm{~cm}$ & 213.05 & 75.0 & -35.8 & REV & $3.00 \times 10^{-8}$ \\
\hline $8 \mathrm{R}-1,65 \mathrm{~cm}$ & 213.65 & 20.7 & -18.8 & REP & $3.13 \times 10^{-8}$ \\
\hline $8 \mathrm{R}-1,87 \mathrm{~cm}$ & 213.87 & 274.1 & 35.6 & NOR & $6.47 \times 10^{-8}$ \\
\hline $641 \mathrm{C}-7 \mathrm{R}-2,45 \mathrm{~cm}$ & 210.65 & 326.3 & 33.0 & NOR & $3.57 \times 10^{-7}$ \\
\hline $7 \mathrm{R}-2,89 \mathrm{~cm}$ & 211.09 & 106.2 & 38.1 & NOR & $3.95 \times 10^{-6}$ \\
\hline $8 \mathrm{R}-1,46 \mathrm{~cm}$ & 218.86 & 183.8 & 40.8 & NOR & $7.30 \times 10^{-8}$ \\
\hline $8 \mathrm{R}-1,69 \mathrm{~cm}$ & 219.09 & 261.6 & 54.1 & NOR & $8.14 \times 10^{-8}$ \\
\hline $8 \mathrm{R}-2,10 \mathrm{~cm}$ & 220.00 & 295.5 & 50.4 & NOR & $5.54 \times 10^{-8}$ \\
\hline $8 \mathrm{R}-4,128 \mathrm{~cm}$ & 224.18 & 72.1 & 38.8 & NOP & $5.15 \times 10^{-9}$ \\
\hline $8 \mathrm{R}-5,11 \mathrm{~cm}$ & 224.51 & 69.9 & 34.7 & NOP & $1.79 \times 10^{-8}$ \\
\hline $9 \mathrm{R}-1,61 \mathrm{~cm}$ & 228.61 & 209.0 & 30.6 & NOR & $8.34 \times 10^{-8}$ \\
\hline
\end{tabular}




\begin{tabular}{|c|c|c|c|c|c|}
\hline \multirow[b]{2}{*}{ Sample } & \multirow[b]{2}{*}{$\begin{array}{l}\text { Depth } \\
\text { (mbsf) }\end{array}$} & \multicolumn{4}{|c|}{ Characteristic magnetization } \\
\hline & & Declination & Inclination & Polarity & $\begin{array}{l}\text { Intensity } \\
\left(\mathrm{emu} / \mathrm{cm}^{3}\right)\end{array}$ \\
\hline $9 \mathrm{R}-1,104 \mathrm{~cm}$ & 229.04 & 223.4 & 36.0 & NOR & $1.62 \times 10^{-7}$ \\
\hline $9 \mathrm{R}-2,26 \mathrm{~cm}$ & 229.67 & 231.9 & 27.0 & NOR & $5.21 \times 10^{-7}$ \\
\hline $9 \mathrm{R}-2,92 \mathrm{~cm}$ & 230.42 & 25.1 & 8.5 & NOP & $3.24 \times 10^{-7}$ \\
\hline $9 \mathrm{R}-3,28 \mathrm{~cm}$ & 231.28 & 146.4 & 48.0 & NOR & $2.59 \times 10^{-7}$ \\
\hline $9 \mathrm{R}-3,102 \mathrm{~cm}$ & 232.02 & 143.9 & 32.7 & NOR & $2.00 \times 10^{-7}$ \\
\hline $10 \mathrm{R}-1,16 \mathrm{~cm}$ & 237.76 & 87.0 & 67.5 & N?? & $2.43 \times 10^{-8}$ \\
\hline $10 \mathrm{R}-1,78 \mathrm{~cm}$ & 238.38 & 6.5 & 34.3 & NOP & $3.44 \times 10^{-8}$ \\
\hline $10 \mathrm{R}-2,36 \mathrm{~cm}$ & 239.46 & 280.7 & 45.7 & NOP & $2.71 \times 10^{-8}$ \\
\hline $10 \mathrm{R}-2,72 \mathrm{~cm}$ & 239.82 & 97.3 & -22.1 & REV & $1.29 \times 10^{-8}$ \\
\hline $10 \mathrm{R}-2,134 \mathrm{~cm}$ & 240.44 & 84.6 & -7.1 & REV & $1.23 \times 10^{-7}$ \\
\hline $10 \mathrm{R}-3,23 \mathrm{~cm}$ & 240.83 & 74.8 & -25.3 & REV & $1.29 \times 10^{-7}$ \\
\hline $10 \mathrm{R}-3,87 \mathrm{~cm}$ & 241.47 & 77.7 & -12.7 & REP & $2.02 \times 10^{-8}$ \\
\hline $10 \mathrm{R}-3,137 \mathrm{~cm}$ & 241.97 & 77.1 & -22.4 & REV & $4.18 \times 10^{-8}$ \\
\hline $10 \mathrm{R}-4,21 \mathrm{~cm}$ & 242.31 & 10.7 & 15.3 & R?? & $1.36 \times 10^{-8}$ \\
\hline $10 \mathrm{R}-4,59 \mathrm{~cm}$ & 242.69 & 69.7 & -18.6 & REP & $4.59 \times 10^{-8}$ \\
\hline $10 \mathrm{R}-4,133 \mathrm{~cm}$ & 243.43 & 243.8 & 34.1 & NOP & $1.70 \times 10^{-8}$ \\
\hline $10 \mathrm{R}-5,57 \mathrm{~cm}$ & 244.17 & 272.2 & 27.9 & NOR & $4.40 \times 10^{-8}$ \\
\hline $10 \mathrm{R}-5,97 \mathrm{~cm}$ & 244.57 & 303.2 & 28.7 & NOP & $5.86 \times 10^{-8}$ \\
\hline $10 \mathrm{R}-6,5 \mathrm{~cm}$ & 245.15 & 12.9 & 51.4 & NOR & $3.52 \times 10^{-8}$ \\
\hline $10 \mathrm{R}-6,62 \mathrm{~cm}$ & 245.72 & 211.1 & 43.4 & NOR & $1.95 \times 10^{-8}$ \\
\hline $10 \mathrm{R}-7,10 \mathrm{~cm}$ & 245.84 & 286.3 & 37.6 & N?? & $2.21 \times 10^{-8}$ \\
\hline $11 \mathrm{R}-1,17 \mathrm{~cm}$ & 247.47 & 242.2 & 35.5 & NOR & $1.78 \times 10^{-8}$ \\
\hline $11 \mathrm{R}-1,67 \mathrm{~cm}$ & 247.97 & 268.1 & 46.1 & NOP & $1.75 \times 10^{-8}$ \\
\hline $11 \mathrm{R}-1,144 \mathrm{~cm}$ & 248.74 & 291.4 & 21.0 & NOR & $8.01 \times 10^{-8}$ \\
\hline $11 \mathrm{R}-2,36 \mathrm{~cm}$ & 249.16 & 284.0 & 26.2 & NOR & $9.82 \times 10^{-8}$ \\
\hline $11 \mathrm{R}-2,95 \mathrm{~cm}$ & 249.75 & 257.8 & 29.7 & NOR & $1.20 \times 10^{-7}$ \\
\hline $11 \mathrm{R}-2,149 \mathrm{~cm}$ & 250.29 & 248.6 & 25.2 & NOR & $1.31 \times 10^{-7}$ \\
\hline $11 \mathrm{R}-3,31 \mathrm{~cm}$ & 250.61 & 305.4 & 35.0 & NOR & $5.81 \times 10^{-8}$ \\
\hline $11 \mathrm{R}-3,91 \mathrm{~cm}$ & 251.21 & 255.5 & 37.0 & NOR & $7.34 \times 10^{-8}$ \\
\hline $11 \mathrm{R}-4,33 \mathrm{~cm}$ & 252.13 & 282.6 & 22.8 & NOP & $2.07 \times 10^{-8}$ \\
\hline $11 \mathrm{R}-4,87 \mathrm{~cm}$ & 252.67 & 284.0 & 4.5 & N?? & $1.32 \times 10^{-8}$ \\
\hline $11 \mathrm{R}-5,10 \mathrm{~cm}$ & 253.40 & 224.5 & 38.0 & NOR & $2.31 \times 10^{-8}$ \\
\hline $11 \mathrm{R}-6,7 \mathrm{~cm}$ & 253.52 & 182.8 & 53.9 & NOP & $1.09 \times 10^{-8}$ \\
\hline $12 \mathrm{R}-1,12 \mathrm{~cm}$ & 257.02 & 253.3 & 45.6 & NOR & $9.84 \times 10^{-9}$ \\
\hline $12 \mathrm{R}-1,68 \mathrm{~cm}$ & 257.58 & 235.5 & 45.7 & NOP & $1.39 \times 10^{-8}$ \\
\hline $12 \mathrm{R}-1,120 \mathrm{~cm}$ & 258.10 & 265.5 & 35.3 & NOR & $3.08 \times 10^{-8}$ \\
\hline $12 \mathrm{R}-2,11 \mathrm{~cm}$ & 258.51 & 47.7 & 36.4 & N?? & $1.25 \times 10^{-6}$ \\
\hline $12 \mathrm{R}-2,65 \mathrm{~cm}$ & 259.05 & 145.6 & 56.0 & NOP & $8.46 \times 10^{-9}$ \\
\hline $12 \mathrm{R}-2,119 \mathrm{~cm}$ & 259.59 & 274.5 & 45.6 & NOR & $1.33 \times 10^{-8}$ \\
\hline $12 \mathrm{R}-3,13 \mathrm{~cm}$ & 260.03 & 272.2 & 22.0 & NOR & $2.41 \times 10^{-8}$ \\
\hline $12 \mathrm{R}-3,62 \mathrm{~cm}$ & 260.52 & 263.1 & 31.9 & NOR & $1.96 \times 10^{-8}$ \\
\hline $12 \mathrm{R}-3,109 \mathrm{~cm}$ & 260.99 & 265.1 & 29.1 & NOP & $1.80 \times 10^{-8}$ \\
\hline $12 \mathrm{R}-4,14 \mathrm{~cm}$ & 261.54 & 260.9 & 38.6 & NOP & $9.65 \times 10^{-9}$ \\
\hline $12 \mathrm{R}-4,62 \mathrm{~cm}$ & 262.02 & 235.9 & 31.3 & NOP & $8.83 \times 10^{-9}$ \\
\hline $12 \mathrm{R}-4,117 \mathrm{~cm}$ & 262.57 & 290.2 & 30.8 & NOP & $3.61 \times 10^{-8}$ \\
\hline $12 \mathrm{R}-5,15 \mathrm{~cm}$ & 263.05 & 225.2 & 28.5 & NOP & $1.59 \times 10^{-8}$ \\
\hline $12 \mathrm{R}-5,57 \mathrm{~cm}$ & 263.47 & 313.7 & 31.9 & NOR & $4.29 \times 10^{-8}$ \\
\hline $12 \mathrm{R}-5,114 \mathrm{~cm}$ & 264.04 & 313.9 & 28.4 & NOP & $1.72 \times 10^{-8}$ \\
\hline $12 \mathrm{R}-6,7 \mathrm{~cm}$ & 264.47 & 265.0 & 38.9 & NOR & $1.96 \times 10^{-8}$ \\
\hline $12 \mathrm{R}-6,63 \mathrm{~cm}$ & 265.03 & 239.6 & 28.8 & NOP & $2.60 \times 10^{-8}$ \\
\hline $12 \mathrm{R}-6,109 \mathrm{~cm}$ & 265.49 & 251.5 & 41.0 & NOR & $1.29 \times 10^{-8}$ \\
\hline $12 \mathrm{R}-7,10 \mathrm{~cm}$ & 266.01 & 279.8 & 38.6 & NOR & $1.81 \times 10^{-8}$ \\
\hline $12 \mathrm{R}-7,33 \mathrm{~cm}$ & 266.23 & 315.8 & 38.5 & N?? & $1.56 \times 10^{-8}$ \\
\hline $13 \mathrm{R}-1,14 \mathrm{~cm}$ & 266.64 & 276.7 & 43.4 & NOR & $1.82 \times 10^{-8}$ \\
\hline $13 \mathrm{R}-1,49 \mathrm{~cm}$ & 266.99 & 289.7 & 37.9 & NOR & $2.72 \times 10^{-8}$ \\
\hline $13 \mathrm{R}-1,103 \mathrm{~cm}$ & 267.53 & 2.8 & 41.6 & NOR & $2.10 \times 10^{-8}$ \\
\hline $13 \mathrm{R}-2,52 \mathrm{~cm}$ & 268.52 & 298.0 & 46.2 & NOR & $1.78 \times 10^{-8}$ \\
\hline $13 \mathrm{R}-2,100 \mathrm{~cm}$ & 269.00 & 206.1 & 36.9 & NOP & $8.30 \times 10^{-9}$ \\
\hline $13 \mathrm{R}-3,8 \mathrm{~cm}$ & 269.58 & 300.2 & 44.9 & NOR & $2.19 \times 10^{-8}$ \\
\hline $13 \mathrm{R}-3,63 \mathrm{~cm}$ & 270.13 & 220.5 & 41.1 & NOP & $1.59 \times 10^{-8}$ \\
\hline $13 \mathrm{R}-3,134 \mathrm{~cm}$ & 270.84 & 278.9 & 52.3 & NOR & $1.87 \times 10^{-8}$ \\
\hline $13 \mathrm{R}-4,21 \mathrm{~cm}$ & 271.21 & 264.8 & 55.0 & NOP & $1.58 \times 10^{-8}$ \\
\hline $13 \mathrm{R}-4,65 \mathrm{~cm}$ & 271.65 & 302.8 & 41.5 & N?? & $1.41 \times 10^{-8}$ \\
\hline $13 \mathrm{R}-4,134 \mathrm{~cm}$ & 272.34 & 283.9 & 33.1 & NOR & $1.39 \times 10^{-7}$ \\
\hline $13 \mathrm{R}-5,22 \mathrm{~cm}$ & 272.72 & 289.3 & 32.9 & NOP & $3.24 \times 10^{-8}$ \\
\hline $13 \mathrm{R}-6,2 \mathrm{~cm}$ & 273.67 & 93.1 & 38.9 & NOR & $1.26 \times 10^{-8}$ \\
\hline $14 \mathrm{R}-1,53 \mathrm{~cm}$ & 276.73 & 277.6 & 42.4 & NOR & $2.46 \times 10^{-8}$ \\
\hline $14 \mathrm{R}-1,106 \mathrm{~cm}$ & 277.26 & 290.8 & 40.7 & NOR & $1.35 \times 10^{-8}$ \\
\hline $14 \mathrm{R}-2,32 \mathrm{~cm}$ & 278.02 & 32.0 & 52.0 & NOR & $1.99 \times 10^{-8}$ \\
\hline $14 \mathrm{R}-2,75 \mathrm{~cm}$ & 278.45 & 85.7 & 38.4 & NOR & $1.21 \times 10^{-8}$ \\
\hline $14 \mathrm{R}-2,139 \mathrm{~cm}$ & 279.09 & 112.2 & 48.2 & NOR & $2.44 \times 10^{-8}$ \\
\hline $14 \mathrm{R}-3,23 \mathrm{~cm}$ & 279.43 & 41.3 & 30.1 & NOR & $3.18 \times 10^{-8}$ \\
\hline $14 \mathrm{R}-3,79 \mathrm{~cm}$ & 279.99 & 326.5 & 29.4 & NOP & $1.58 \times 10^{-8}$ \\
\hline $14 \mathrm{R}-3,149 \mathrm{~cm}$ & 280.69 & 327.8 & 40.8 & NOR & $1.39 \times 10^{-8}$ \\
\hline $14 \mathrm{R}-4,27 \mathrm{~cm}$ & 280.97 & 289.5 & 37.9 & NOR & $3.49 \times 10^{-8}$ \\
\hline $14 \mathrm{R}-4,83 \mathrm{~cm}$ & 281.53 & 283.6 & 39.9 & NOR & $1.23 \times 10^{-8}$ \\
\hline $14 \mathrm{R}-4,149 \mathrm{~cm}$ & 282.19 & 291.8 & 20.8 & NOR & $2.23 \times 10^{-8}$ \\
\hline
\end{tabular}


Appendix (continued).

\begin{tabular}{|c|c|c|c|c|c|}
\hline \multirow[b]{2}{*}{ Sample } & \multirow[b]{2}{*}{$\begin{array}{l}\text { Depth } \\
\text { (mbsf) }\end{array}$} & \multicolumn{4}{|c|}{ Characteristic magnetization } \\
\hline & & Declination & Inclination & Polarity & $\begin{array}{l}\text { Intensity } \\
\left(\mathrm{emu} / \mathrm{cm}^{3}\right)\end{array}$ \\
\hline $14 \mathrm{R}-5,20 \mathrm{~cm}$ & 282.40 & 302.6 & 16.1 & NOP & $2.57 \times 10^{-8}$ \\
\hline $14 \mathrm{R}-5,81 \mathrm{~cm}$ & 283.01 & 285.7 & 37.9 & NOR & $1.78 \times 10^{-8}$ \\
\hline $14 \mathrm{R}-5,119 \mathrm{~cm}$ & 283.39 & 275.4 & 34.5 & NOR & $2.00 \times 10^{-8}$ \\
\hline $14 \mathrm{R}-6,14 \mathrm{~cm}$ & 283.84 & 304.3 & 37.7 & $\mathrm{~N} ? ?$ & $3.48 \times 10^{-8}$ \\
\hline $14 \mathrm{R}-6,73 \mathrm{~cm}$ & 284.43 & 276.1 & 32.0 & NOR & $1.74 \times 10^{-8}$ \\
\hline $14 \mathrm{R}-6,149 \mathrm{~cm}$ & 285.19 & 272.0 & 42.3 & NOR & $2.59 \times 10^{-8}$ \\
\hline $14 \mathrm{R}-7,8 \mathrm{~cm}$ & 285.28 & 250.9 & 44.5 & NOR & $3.52 \times 10^{-8}$ \\
\hline $15 \mathrm{R}-1,27 \mathrm{~cm}$ & 286.07 & 258.9 & 41.7 & NOP & $2.31 \times 10^{-8}$ \\
\hline $15 \mathrm{R}-1,89 \mathrm{~cm}$ & 286.69 & 262.0 & 35.3 & NOR & $4.70 \times 10^{-8}$ \\
\hline $15 \mathrm{R}-1,132 \mathrm{~cm}$ & 287.12 & 264.4 & 51.6 & NOR & $1.86 \times 10^{-8}$ \\
\hline $15 \mathrm{R}-2,30 \mathrm{~cm}$ & 287.60 & 251.1 & 43.1 & NOR & $3.98 \times 10^{-8}$ \\
\hline $15 \mathrm{R}-2,71 \mathrm{~cm}$ & 288.01 & 290.1 & 32.5 & NOR & $3.58 \times 10^{-8}$ \\
\hline $15 \mathrm{R}-2,108 \mathrm{~cm}$ & 288.38 & 264.1 & 20.1 & NOR & $2.92 \times 10^{-8}$ \\
\hline $15 \mathrm{R}-3,37 \mathrm{~cm}$ & 289.17 & 296.8 & 40.5 & NOR & $4.38 \times 10^{-8}$ \\
\hline $15 \mathrm{R}-3,103 \mathrm{~cm}$ & 289.83 & 352.8 & -46.4 & NOR & $2.01 \times 10^{-8}$ \\
\hline $16 \mathrm{R}-1,9 \mathrm{~cm}$ & 295.59 & 217.0 & 53.2 & NOR & $6.73 \times 10^{-8}$ \\
\hline $16 \mathrm{R}-2,12 \mathrm{~cm}$ & 296.12 & 270.6 & 47.4 & NOR & $1.47 \times 10^{-7}$ \\
\hline $16 \mathrm{R}-2,72 \mathrm{~cm}$ & 296.72 & 300.0 & 38.4 & NOR & $4.56 \times 10^{-8}$ \\
\hline $16 \mathrm{R}-2,112 \mathrm{~cm}$ & 297.12 & 271.1 & 46.0 & NOR & $2.57 \times 10^{-8}$ \\
\hline $16 \mathrm{R}-3,10 \mathrm{~cm}$ & 297.60 & 271.7 & 33.8 & NOR & $3.22 \times 10^{-8}$ \\
\hline $16 \mathrm{R}-3,69 \mathrm{~cm}$ & 298.19 & 331.3 & 49.6 & NOR & $2.74 \times 10^{-8}$ \\
\hline $16 \mathrm{R}-3,116 \mathrm{~cm}$ & 298.66 & 287.2 & 49.5 & NOR & $2.58 \times 10^{-8}$ \\
\hline $16 \mathrm{R}-4,25 \mathrm{~cm}$ & 299.25 & 251.6 & 44.0 & NOR & $3.59 \times 10^{-8}$ \\
\hline $16 \mathrm{R}-4,77 \mathrm{~cm}$ & 299.77 & 270.4 & 36.8 & NOR & $2.99 \times 10^{-8}$ \\
\hline $16 \mathrm{R}-4,126 \mathrm{~cm}$ & 300.26 & 246.5 & 36.0 & NOP & $2.50 \times 10^{-8}$ \\
\hline $16 \mathrm{R}-5,15 \mathrm{~cm}$ & 300.65 & 268.3 & 34.8 & NOR & $3.17 \times 10^{-8}$ \\
\hline $16 \mathrm{R}-5,71 \mathrm{~cm}$ & 301.21 & 271.9 & 43.2 & NOR & $2.36 \times 10^{-8}$ \\
\hline $16 \mathrm{R}-5,121 \mathrm{~cm}$ & 301.71 & 10.2 & 40.1 & NOR & $1.86 \times 10^{-8}$ \\
\hline $16 \mathrm{R}-6,38 \mathrm{~cm}$ & 303.38 & 271.1 & 53.2 & NOP & $1.31 \times 10^{-8}$ \\
\hline $16 \mathrm{R}-6,69 \mathrm{~cm}$ & 302.69 & 290.5 & 37.6 & NOR & $2.11 \times 10^{-8}$ \\
\hline $16 \mathrm{R}-6,109 \mathrm{~cm}$ & 303.09 & 273.9 & 34.5 & NOR & $1.55 \times 10^{-8}$ \\
\hline $16 \mathrm{R}-7,30 \mathrm{~cm}$ & 303.80 & 286.1 & 40.9 & NOR & $2.05 \times 10^{-8}$ \\
\hline $16 \mathrm{R}-7,86 \mathrm{~cm}$ & 304.36 & 290.7 & 26.6 & NOR & $1.65 \times 10^{-8}$ \\
\hline $16 \mathrm{R}-7,133 \mathrm{~cm}$ & 304.83 & 261.6 & 57.6 & NOP & $9.42 \times 10^{-9}$ \\
\hline $16 \mathrm{R}-8,11 \mathrm{~cm}$ & 305.11 & 295.9 & 8.6 & N?? & $2.37 \times 10^{-8}$ \\
\hline $16 \mathrm{R}-8,51 \mathrm{~cm}$ & 305.51 & 320.2 & 63.2 & NOP & $8.24 \times 10^{-9}$ \\
\hline $16 \mathrm{R}-9,20 \mathrm{~cm}$ & 305.85 & 329.5 & 64.9 & NOP & $1.72 \times 10^{-8}$ \\
\hline $641 \mathrm{~A}-1 \mathrm{X}-1,67 \mathrm{~cm}$ & 0.67 & 176.6 & 31.8 & NOP & $8.45 \times 10^{-6}$ \\
\hline $1 \mathrm{X}-1,124 \mathrm{~cm}$ & 1.24 & 115.4 & 62.4 & NOP & $6.24 \times 10^{-6}$ \\
\hline $1 X-2,9 \mathrm{~cm}$ & 1.59 & 45.2 & 50.9 & NOP & $9.43 \times 10^{-6}$ \\
\hline $1 X-2,93 \mathrm{~cm}$ & 2.43 & 211.8 & 54.0 & NOP & $9.64 \times 10^{-6}$ \\
\hline $1 X-2,135 \mathrm{~cm}$ & 2.85 & 186.8 & 43.7 & NOP & $1.17 \times 10^{-5}$ \\
\hline $1 X-3,71 \mathrm{~cm}$ & 3.71 & 241.4 & 43.7 & N?? & $5.83 \times 10^{-6}$ \\
\hline $1 X-3,106 \mathrm{~cm}$ & 4.06 & 28.6 & 2.2 & $\mathrm{R}$ ?? & $2.74 \times 10^{-7}$ \\
\hline $1 \mathrm{X}-4,21 \mathrm{~cm}$ & 4.71 & 231.0 & 68.7 & NOP & $3.54 \times 10^{-6}$ \\
\hline $1 X-5,5 \mathrm{~cm}$ & 5.22 & 216.6 & 54.1 & NOP & $7.63 \times 10^{-6}$ \\
\hline $2 \mathrm{X}-1,45 \mathrm{~cm}$ & 6.55 & 244.3 & 46.9 & NOP & $7.93 \times 10^{-6}$ \\
\hline $2 \mathrm{X}-1,98 \mathrm{~cm}$ & 7.08 & 226.9 & 31.2 & N?? & $3.24 \times 10^{-6}$ \\
\hline $2 \mathrm{X}-2,4 \mathrm{~cm}$ & 7.64 & 209.5 & -23.2 & REP & $2.67 \times 10^{-6}$ \\
\hline $2 \mathrm{X}-3,37 \mathrm{~cm}$ & 9.47 & 185.8 & 54.1 & NOP & $1.58 \times 10^{-5}$ \\
\hline $2 \mathrm{X}-4,36 \mathrm{~cm}$ & 10.96 & 296.5 & 1.8 & REP & $3.47 \times 10^{-6}$ \\
\hline $2 X-5,65 \mathrm{~cm}$ & 12.75 & 284.3 & 82.1 & INT & $1.86 \times 10^{-6}$ \\
\hline $2 X-5,125 \mathrm{~cm}$ & 13.35 & 55.3 & 12.2 & $\mathrm{R} ? ?$ & $1.64 \times 10^{-6}$ \\
\hline $2 \mathrm{X}-6,42 \mathrm{~cm}$ & 14.02 & 37.2 & -2.7 & REP & $7.57 \times 10^{-7}$ \\
\hline $3 \mathrm{X}-1,8 \mathrm{~cm}$ & 15.78 & 37.1 & 48.0 & NOR & $4.07 \times 10^{-6}$ \\
\hline $3 \mathrm{X}-1,49 \mathrm{~cm}$ & 16.19 & 294.7 & 59.7 & N?? & $2.97 \times 10^{-6}$ \\
\hline $3 \mathrm{X}-1,102 \mathrm{~cm}$ & 16.72 & 216.7 & 55.2 & NOR & $7.71 \times 10^{-6}$ \\
\hline $3 \mathrm{X}-2,9 \mathrm{~cm}$ & 17.29 & 211.0 & 39.5 & NOR & $3.54 \times 10^{-6}$ \\
\hline $3 \mathrm{X}-2,93 \mathrm{~cm}$ & 18.13 & 302.3 & 48.3 & NOR & $5.76 \times 10^{-6}$ \\
\hline $3 \mathrm{X}-2,126 \mathrm{~cm}$ & 18.46 & 306.3 & 31.8 & NOR & $5.97 \times 10^{-6}$ \\
\hline $3 \mathrm{X}-3,2 \mathrm{~cm}$ & 18.72 & 293.0 & 30.4 & NOR & $4.57 \times 10^{-6}$ \\
\hline $3 \mathrm{X}-4,9 \mathrm{~cm}$ & 18.92 & 96.8 & -16.3 & INT & $1.57 \times 10^{-6}$ \\
\hline $3 \mathrm{X}-4,40 \mathrm{~cm}$ & 19.24 & 83.7 & 65.7 & INT & $3.00 \times 10^{-6}$ \\
\hline $4 \mathrm{X}-1,32 \mathrm{~cm}$ & 25.62 & 331.7 & 19.6 & $\mathrm{R}$ ?? & $7.85 \times 10^{-6}$ \\
\hline $4 X-1,72 \mathrm{~cm}$ & 26.02 & 131.4 & -17.1 & REP & $2.54 \times 10^{-6}$ \\
\hline $4 X-2,31 \mathrm{~cm}$ & 26.50 & 238.6 & 53.4 & NOR & $2.47 \times 10^{-6}$ \\
\hline $5 X-3,31 \mathrm{~cm}$ & 38.21 & 190.3 & 26.3 & NOP & $8.78 \times 10^{-6}$ \\
\hline $5 \mathrm{X}-3,75 \mathrm{~cm}$ & 38.65 & 202.2 & 61.2 & NOR & $5.15 \times 10^{-6}$ \\
\hline $6 \mathrm{X}-1,81 \mathrm{~cm}$ & 45.31 & 232.9 & -18.0 & REV & $1.08 \times 10^{-5}$ \\
\hline $6 \mathrm{X}-3,90 \mathrm{~cm}$ & 48.40 & 16.9 & 41.4 & INT & $1.41 \times 10^{-5}$ \\
\hline $6 \mathrm{X}-4,46 \mathrm{~cm}$ & 49.46 & 225.5 & 58.6 & NOP & $2.39 \times 10^{-5}$ \\
\hline $6 \mathrm{X}-5,24 \mathrm{~cm}$ & 50.74 & 241.7 & -20.1 & REP & $4.67 \times 10^{-6}$ \\
\hline $6 \mathrm{X}-5,125 \mathrm{~cm}$ & 51.75 & 93.4 & 51.7 & NOP & $3.56 \times 10^{-6}$ \\
\hline $7 X-1,138 \mathrm{~cm}$ & 55.48 & 106.8 & 24.7 & NOP & $3.47 \times 10^{-8}$ \\
\hline $7 X-5,141 \mathrm{~cm}$ & 61.51 & 303.1 & 34.9 & NOP & $7.64 \times 10^{-8}$ \\
\hline
\end{tabular}

